UNIVERSIDADE DE SÃO PAULO

CENTRO DE ENERGIA NUCLEAR NA AGRICULTURA

MARCELA ARNALDO

Relações entre fluxos de óxido nitroso $\left(\mathrm{N}_{2} \mathrm{O}\right)$ com umidade e genes associados à desnitrificação em floresta e sistemas agrícolas 



\section{MARCELA ARNALDO}

Relações entre fluxos de óxido nitroso $\left(\mathrm{N}_{2} \mathrm{O}\right)$ com umidade e genes associados à desnitrificação em floresta e sistemas agrícolas

Dissertação apresentada ao Centro de Energia Nuclear na Agricultura da Universidade de São Paulo para obtenção do título de Mestre em Ciências

Área de Concentração: Biologia na Agricultura e no Ambiente

Orientador: Prof. Dr. João Lúcio de Azevedo 
AUTORIZO A DIVULGAÇÃO TOTAL OU PARCIAL DESTE TRABALHO, POR QUALQUER MEIO CONVENCIONAL OU ELETRÔNICO, PARA FINS DE ESTUDO E PESQUISA, DESDE QUE CITADA A FONTE.

Dados Internacionais de Catalogação na Publicação (CIP)

Seção Técnica de Biblioteca - CENA/USP

Arnaldo, Marcela

Relações entre fluxos de óxido nitroso $\left(\mathrm{N}_{2} \mathrm{O}\right)$ com umidade e genes associados à desnitrificação em floresta e sistemas agrícolas / Marcela Arnaldo; orientador João Lúcio de Azevedo. - - Piracicaba, 2014.

84 f.: il.

Dissertação (Mestrado - Programa de Pós-Graduação em Ciências. Área de Concentração: Biologia na Agricultura e no Ambiente) - Centro de Energia Nuclear na Agricultura da Universidade de São Paulo.

1. Bactérias desnitrificantes 2. Biologia molecular 3. Ciclos biogeoquímicos 4. Ecologia microbiana 5. Efeito estufa 6. Nitrogênio I. Título 
Dedico este trabalho aos meus pais, Roberto e Maria Ângela, e aos meus queridos irmãos, Thiago e Diego. 


\section{AGRADECIMENTOS}

A Deus, por estar sempre presente em minha vida;

Aos meus pais e irmãos, por sempre estarem ao meu lado, me apoiando em todas as decisões e me incentivando a seguir meu próprio caminho;

Aos professores Dr. João Lúcio de Azevedo e Dra Siu Mui Tsai, pelas pessoas admiráveis e inspiradoras que são, pela orientação e pelo suporte para a realização deste trabalho;

Ao meu namorado Rodrigo, pelo companheirismo excepcional e por toda compreensão e disposição em ajudar;

Aos professores Dr. Carlos Clemente Cerri e Dra Brigitte Josefine Feigl, pela disponibilização de materiais e equipamentos fundamentais para a realização de minha pesquisa;

Aos técnicos do Laboratório de Biogeoquímica Ambiental do CENA/USP, Lilian e Ralf, por toda a ajuda com as análises e pela agradável companhia;

Ao pessoal da fazenda Capuava, pela disponibilização das áreas de coleta, em especial ao Sr. Francisco;

À CAPES, pela concessão da bolsa de Mestrado;

À bibliotecária Marília Henyei, pela formatação do trabalho;

Aos funcionários Fábio, Daiane e Neuda, por toda a ajuda com os prazos e processos administrativos (principalmente nos momentos de pânico!);

Aos técnicos de laboratório de Biologia Celular e Molecular do CENA/USP: Chiquinho (in memoriam), Elias, Fábio e Wagner, por todo o auxílio durante as coletas e com a aquisição dos materiais necessários para a execução deste trabalho, mas, principalmente, pela amizade construída durante todos esses anos; 
Às pessoas muito queridas que tive a oportunidade de conhecer: Acácio, Aline Morgan, Andreza, Bia, Carol, Clóvis, Dani, Dennis, Enéas, Fabi, Felippe, Fernanda Cassieri, Fernanda Nakamura, Gustavo, Helena, Lina, Lucas, Lucas Palma, Mari, Marininha, Maju, Paulinha e Rosineide. Foi um prazer conviver com todos vocês!;

Ao trio inseparável, Andressa, Aline e Caio, à minha querida amiga Marília e ao meu casal preferido, Naissa e Franz, pela amizade verdadeira, por toda a ajuda e por estarem sempre presentes, na alegria e na tristeza, na saúde e na doença, em todos os dias do meu mestrado! Vou sentir muita, muita, muita falta de vocês!;

A todos que de alguma forma contribuíram com a execução deste trabalho.

\section{Muito Obrigada!!!}


"Por vezes sentimos que aquilo que fazemos não é senão uma gota de água no mar. Mas o mar seria menor se lhe faltasse uma gota." Madre Teresa de Calcutá 


\section{RESUMO}

ARNALDO, M. Relações entre fluxos de óxido nitroso $\left(\mathrm{N}_{2} \mathrm{O}\right)$ com umidade e genes associados à desnitrificação em floresta e sistemas agrícolas. 2014. 84 f. Dissertação (Mestrado) - Centro de Energia Nuclear na Agricultura, Universidade de São Paulo, Piracicaba, 2014.

$\mathrm{O}$ óxido nitroso $\left(\mathrm{N}_{2} \mathrm{O}\right)$ é um importante gás de efeito estufa (GEE) e, nos ecossistemas terrestres, é produzido principalmente pelo processo de desnitrificação. Esse ocorre em condições anaeróbias e, portanto, é fortemente estimulado pelo aumento do teor de umidade do solo. Entretanto, solos sob diferentes usos podem exibir taxas de emissão de $\mathrm{N}_{2} \mathrm{O}$ distintas, mesmo quando apresentam teores de umidade equivalentes. Ainda não está claro se isso se deve somente ao fato de os mesmos diferirem quanto a atributos físicos e químicos capazes de afetar a atividade dos organismos desnitrificantes ou se também se deve à diferenças com relação ao tamanho de suas populações. O presente trabalho foi desenvolvido com o objetivo de compreender as relações entre os fluxos de $\mathrm{N}_{2} \mathrm{O}$, a umidade e a abundância de genes bacterianos envolvidos no processo de desnitrificação (nirK, norB e nosZ) em solos de floresta, pastagem e cultivo de cana-de-açúcar, utilizando um experimento de microcosmos. Amostras de solo foram coletadas na fazenda Capuava, situada no município de Piracicaba, SP. Os microcosmos estabelecidos a partir das mesmas foram mantidos com diferentes teores de umidade (original e ajustados para atingir $60 \%$ e $90 \%$ da capacidade de campo) e incubados a $30{ }^{\circ} \mathrm{C}$ por 30 dias. Ao longo do período de incubação, os fluxos de $\mathrm{N}_{2} \mathrm{O}$ a partir desses solos foram analisados por cromatografia gasosa. Amostras coletadas do interior dos microcosmos, antes e depois da aplicação dos tratamentos, foram comparadas quanto à estrutura de suas comunidades bacterianas, utilizando a técnica de T-RFLP, e quanto à abundância dos genes $16 \mathrm{~S}$ rRNA, nirK, norB e nosZ, através da técnica de qPCR. Somente os solos que tiveram sua umidade ajustada para $90 \%$ da capacidade de campo exibiram incrementos significativos na produção de $\mathrm{N}_{2} \mathrm{O}$. Em tais amostras, também foi verificada a alteração da estrutura das comunidades bacterianas e do número de cópias dos genes nor $B$ e nosZ. Apenas este último, no entanto, apresentou uma correlação positiva com a umidade do solo. A abundância dos genes avaliados não apresentou correlações significativas com as taxas de emissão do GEE. Por outro lado, as emissões cumulativas de $\mathrm{N}_{2} \mathrm{O}$ se correlacionaram positivamente com as quantidades de genes desnitrificantes presentes inicialmente nas amostras de solo. Estes genes se mostraram mais abundantes nas amostras de pastagem e floresta, as quais apresentavam maiores teores de matéria orgânica, carbono, nitrogênio, nitrato e argila do que aquelas provenientes da área cultivada com cana-de-açúcar. Tais resultados demonstram que o conteúdo de água do solo afeta a taxa de emissão de $\mathrm{N}_{2} \mathrm{O}$, mas que isso não se deve a alterações na abundância das bactérias envolvidas no processo, como as que carregam os genes nirK, norB e nosZ. Aparentemente, no entanto, quantidade de GEE que o solo é capaz de produzir está relacionada ao tamanho das populações desses organismos desnitrificantes.

Palavras-chave: Ciclo biogeoquímico do nitrogênio. Bactérias desnitrificantes. PCR em tempo real. T-RFLP. 


\begin{abstract}
ARNALDO, M. Relations between nitrous oxide $\left(\mathrm{N}_{2} \mathrm{O}\right)$ fluxes with moisture and genes associated with denitrification in forest and agricultural systems. 2014. $84 \mathrm{f}$. Dissertação (Mestrado) - Centro de Energia Nuclear na Agricultura, Universidade de São Paulo, Piracicaba, 2014.
\end{abstract}

Nitrous oxide $\left(\mathrm{N}_{2} \mathrm{O}\right)$ is an important greenhouse gas $(\mathrm{GHG})$ and, in terrestrial ecosystems, it is mainly produced by denitrification. This process occurs under anaerobic conditions and, therefore, is strongly stimulated by the increase of the soil moisture content. However, soils under different uses may exhibit distinct $\mathrm{N}_{2} \mathrm{O}$ emission rates, even when they have the same moisture content. It is still not clear whether this is due solely to the fact that they differ in relation to physical and chemical properties that affect the activity of denitrifying organisms or whether this is also due to differences in the size of their populations. The aim of this work was to evaluate the relations between $\mathrm{N}_{2} \mathrm{O}$ fluxes, moisture and abundance of bacterial genes involved in denitrification process (nirK, norB e nosZ) in soil samples from forest, pasture and sugarcane field, through a microcosm experiment. These samples were collected at Fazenda Capuava, located in Piracicaba, SP. Microcosms established from them were maintained with different moisture contents (original and adjusted to achieve $60 \%$ and $90 \%$ of field capacity) and incubated at $30{ }^{\circ} \mathrm{C}$ for 30 days. During the incubation period, the $\mathrm{N}_{2} \mathrm{O}$ fluxes from soils were analyzed by gas chromatography. Soil samples from microcosms, collected before and after application of the treatments, were compared regarding the structure of their bacterial communities, by using T-RFLP technique, and the abundance of $16 \mathrm{~S}$ rRNA, nirK, norB and nosZ genes, through qPCR technique. Only samples that had their moisture content adjusted to $90 \%$ of field capacity exhibited significant increases in $\mathrm{N}_{2} \mathrm{O}$ production. In these samples, changes in the structure of bacterial communities and in the copy numbers of norB and nos $Z$ genes were also detected. Only the latter gene, however, showed a positive correlation with soil moisture. The abundance of the quantified genes showed no significant correlations with the gas emission rates. On the other hand, the cumulative $\mathrm{N}_{2} \mathrm{O}$ emissions were positively correlated with the amounts of denitrifying genes initially present in the samples. These genes were more abundant in pasture and forest soils, which had higher levels of organic matter, carbon, nitrogen, nitrate and clay than those from sugarcane cropping area. These results indicate that soil water content affects the $\mathrm{N}_{2} \mathrm{O}$ emission rates. However it is not due to changes in the abundance of bacteria involved in the process, such as those that bear the nirK, norB and nos $Z$ genes. Apparently, it is the size of these organisms' populations that determines the amount of GHG that the soil is able to produce.

Keywords: Biogeochemical nitrogen cycle. Denitrifying bacteria. Real-time PCR. T-RFLP. 


\section{SUMÁRIO}

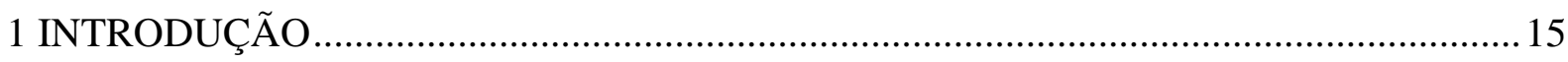

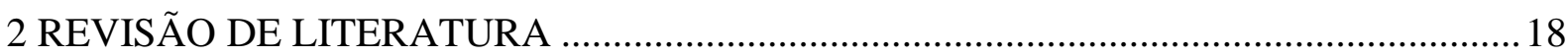

2.1 O processo de desnitrificação e as bactérias desnitrificantes ........................................... 18

2.2 Efeito das variáveis ambientais sobre o processo de desnitrificação .................................20

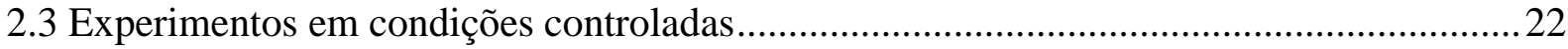

2.4 Uso de técnicas moleculares em Ecologia Microbiana ......................................................2 23

2.4.1 T-RFLP (Terminal Restriction Fragment Length Polymorphism) .................................24

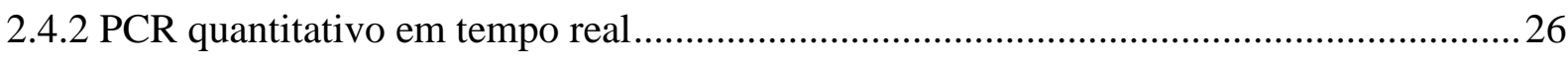

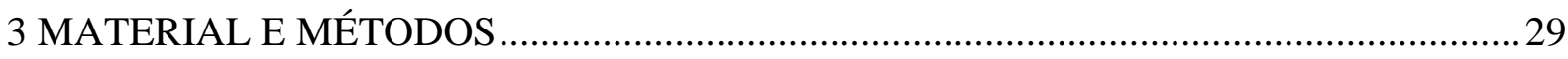

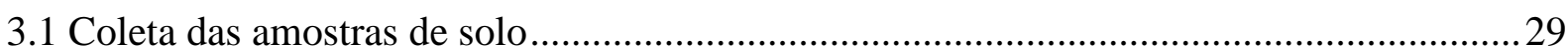

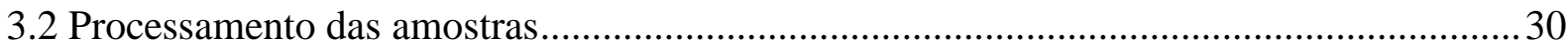

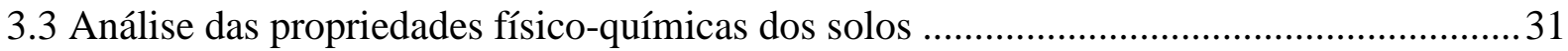

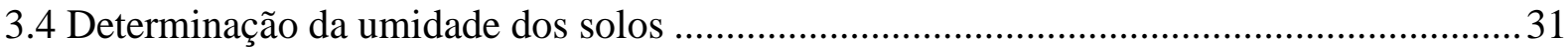

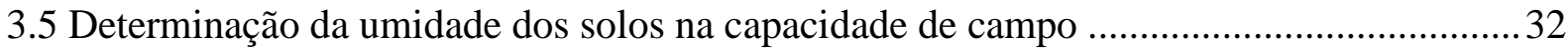

3.6 Montagem e condução do experimento de microcosmos.................................................. 33

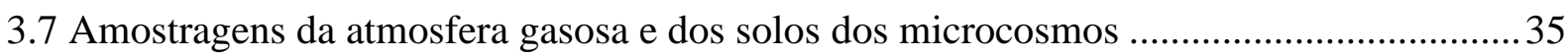

3.8 Análise da atmosfera dos microcosmos por cromatografia gasosa e determinação das

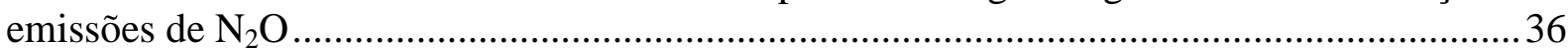

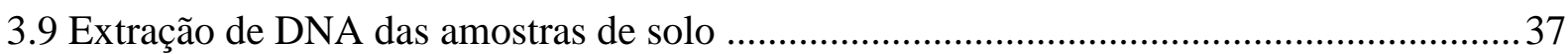

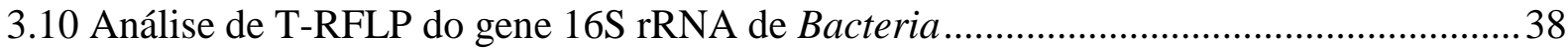

3.10.1 Amplificação do gene 16S rRNA de Bacteria ............................................................. 38

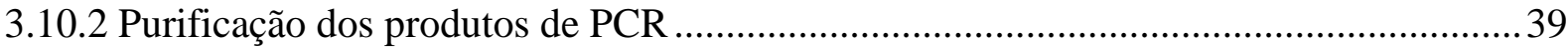

3.10.3 Reação de restrição dos produtos de PCR purificados ..................................................39

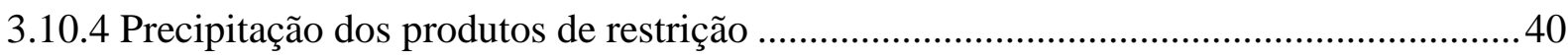

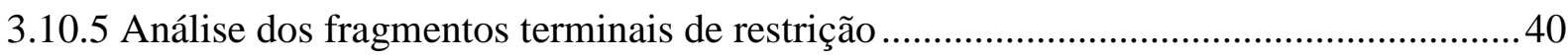

3.10.6 Processamento dos dados para comparação dos perfis de T-RFLP ............................. 40

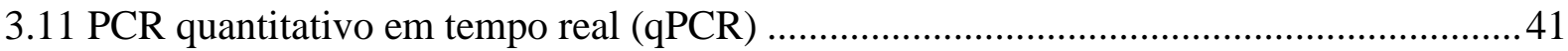

3.11.1 Ensaios para quantificação dos genes 16S rRNA, nirK, cnorB e nosZ ........................ 41

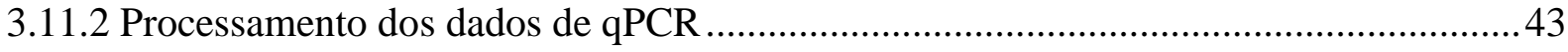

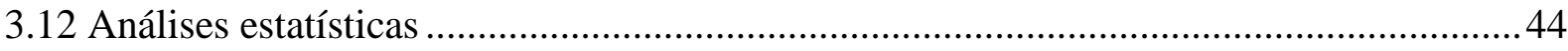

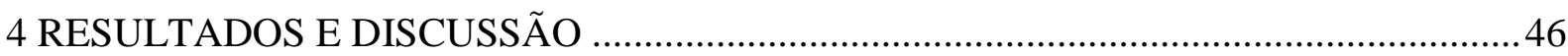

4.1 Caracterização físico-química das amostras de solo utilizadas no experimento .................46

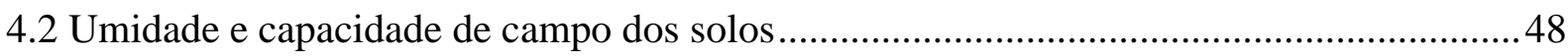

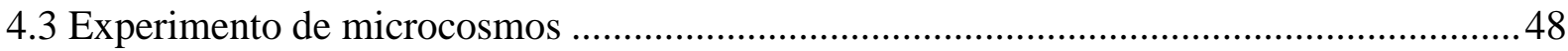

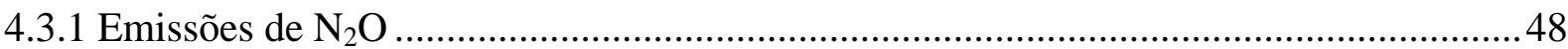

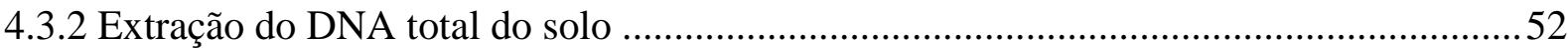




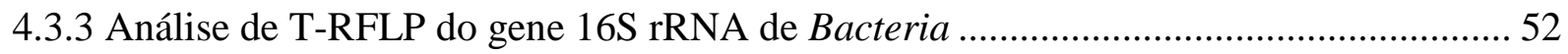

4.3.3.1 Caracterização das comunidades bacterianas dos solos utilizados no experimento .... 52

4.3.3.2 Análise das variações das comunidades bacterianas ao longo do período de incubação

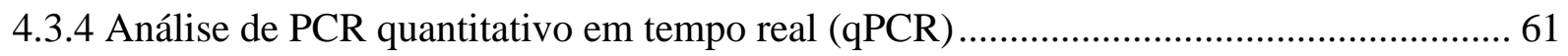

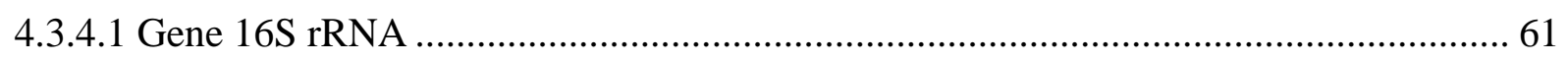

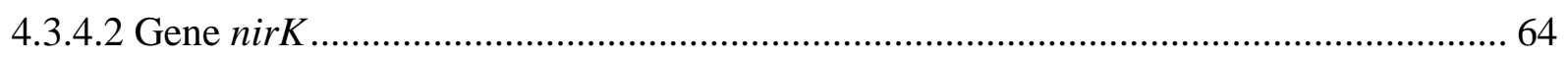

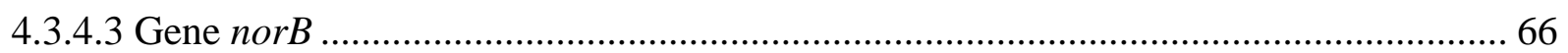

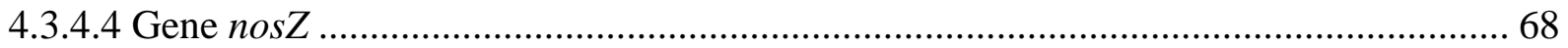

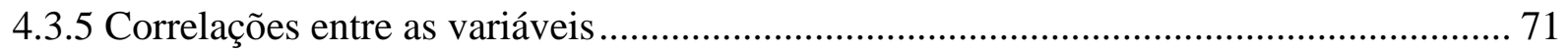

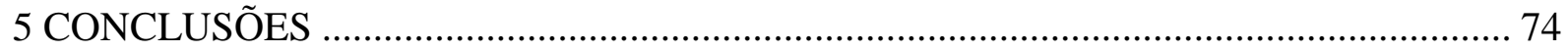

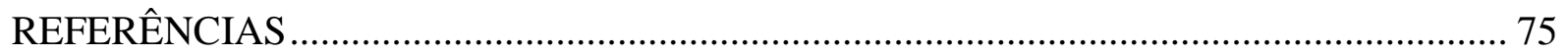




\section{INTRODUÇÃO}

O Efeito Estufa é o fenômeno natural responsável por manter a temperatura média da superfície da Terra numa faixa que varia de $18{ }^{\circ} \mathrm{C}$ a $22{ }^{\circ} \mathrm{C}$, a qual é adequada para as formas de vida existentes (BAIRD, 2002). Ele é causado por gases - chamados gases de efeito estufa (GEE's) - que interagem com a radiação infravermelha, se aquecem e transmitem calor para a atmosfera. O aumento da concentração destes gases pode elevar a temperatura média do planeta e desencadear uma série de mudanças climáticas, tornando mais frequentes os eventos de precipitação intensa e promovendo a ocorrência de ondas de calor e de períodos prolongados de seca (IPCC, 2007; SCHÄR et al., 2004).

$\mathrm{O}$ óxido nitroso $\left(\mathrm{N}_{2} \mathrm{O}\right)$ é considerado um importante GEE porque pode interagir com a radiação infravermelha de maneira muito intensa, apresentando um potencial de aquecimento 300 vezes maior do que o dióxido de carbono $\left(\mathrm{CO}_{2}\right)$ (IPCC, 2007; RAMASWAMY et al., 2001). Além disso, esse gás pode sofrer reações fotoquímicas ao atingir a troposfera, onde passa a atuar como uma fonte de óxidos de nitrogênio capazes de degradar a camada de ozônio (RAVISHANKARA; DANIEL; PORTMANN, 2009).

A concentração de $\mathrm{N}_{2} \mathrm{O}$ na atmosfera vem aumentando desde a Revolução Industrial em consequência do incremento das emissões de origem antrópica (IPCC, 2007). A conversão de florestas em sistemas agrícolas, principalmente em áreas tropicais, está entre as principais atividades humanas associadas à sua produção (PRATHER et al., 1995). Esse tipo de modificação da paisagem pode influenciar os fluxos desse gás porque promove alterações profundas em diversas propriedades do solo, muitas das quais regulam os processos microbianos que levam à sua síntese (BRAKER; CONRAD, 2011).

A tendência é que as áreas agrícolas continuem se expandindo no mundo todo devido à necessidade de produzir mais alimentos para atender às demandas da população em crescimento. Segundo estimativas, essa expansão será acompanhada de medidas voltadas para o aumento da produtividade e vai provocar um incremento de 35 a $60 \%$ nas emissões de $\mathrm{N}_{2} \mathrm{O}$ até 2030 (SMITH et al., 2007), o que torna indispensável o desenvolvimento de estratégias de mitigação das mesmas. Para que isso seja possível, no entanto, é fundamental compreender a ecologia dos organismos envolvidos na sua produção (RICHARDSON et al., 2009).

A desnitrificação é considerada uma das maiores fontes de $\mathrm{N}_{2} \mathrm{O}$ nos ecossistemas terrestres (MOSIER, 1998). Tal processo consiste na conversão do nitrato $\left(\mathrm{NO}_{3}{ }^{-}\right)$a nitrogênio molecular $\left(\mathrm{N}_{2}\right)$ através de várias etapas de redução, e o GEE em questão é um produto 
intermediário obrigatório do mesmo (WRAGE et al., 2001). Estas reações de redução ocorrem sob condições anaeróbias e são realizadas, predominantemente, por bactérias (PHILLIPOT; HALLIN, 2005).

A atividade das bactérias desnitrificantes do solo e, consequentemente, as taxas de produção do $\mathrm{N}_{2} \mathrm{O}$ variam em função de diversos fatores ambientais (WALLENSTEIN et al., 2006). Um dos papéis mais importantes no que se refere à regulação da desnitrificação é desempenhado pelo teor de umidade do solo, pois a água reduz a disponibilidade de oxigênio $\left(\mathrm{O}_{2}\right)$ no mesmo à medida que preenche seu espaço poroso, tornando as condições ideais para que o processo ocorra (SKIBA; SMITH, 2000).

Embora vários estudos já tenham demonstrado a existência de uma correlação positiva entre o conteúdo de água e a produção de $\mathrm{N}_{2} \mathrm{O}$, as taxas de emissão desse gás podem variar consideravelmente entre diferentes solos, mesmo que esses apresentem teores de umidade equivalentes (MCTAGGART et al., 2002). Em geral, assume-se que isso se deve ao fato de os mesmos apresentarem diferenças com relação a atributos capazes de afetar a atividade dos organismos envolvidos no processo, como $\mathrm{pH}$, teores de nitrogênio $(\mathrm{N})$ e carbono $(\mathrm{C})$, etc. Ainda não está claro, no entanto, se isso também depende da abundância com que tais organismos aparecem nas comunidades microbianas (PHILIPPOT et al., 2009).

As relações entre os microrganismos desnitrificantes, as emissões de $\mathrm{N}_{2} \mathrm{O}$ e os teores de umidade do solo podem ser melhor compreendidas se forem avaliadas em condições edáficas distintas. O estudo das mesmas em solos sob diferentes usos, os quais apresentam diferenças quanto a uma série de propriedades físico-químicas (JANGID et al., 2008), pode contribuir para gerar esse tipo de informação. Adicionalmente, pode fornecer indícios de como os microrganismos envolvidos no processo respondem às modificações ambientais e permite averiguar as condições que promovem seu desenvolvimento e atividade.

Recentes avanços em abordagens moleculares, associados ao conhecimento dos genes que codificam as subunidades das enzimas microbianas que catalisam as reações do processo de desnitrificação (como os genes narG, napA, nirK, nirS, norB, nosZ), têm contribuído para o estudo dos organismos que os carregam (BAKKEN et al., 2012). A quantificação desses genes funcionais a partir do DNA microbiano total de amostras ambientais pode ser empregada como uma estratégia eficiente para avaliar a composição das comunidades desnitrificantes estabelecidas nas mesmas (WALLENSTEIN; VILGALYS, 2005). 
Nesse contexto, o objetivo desse estudo foi avaliar qual a associação existente entre a abundância de genes associados à desnitrificação, a umidade e os fluxos de $\mathrm{N}_{2} \mathrm{O}$ em solos de floresta e de sistemas agrícolas, utilizando um estudo de microcosmos. Os sistemas escolhidos foram a monocultura da cana-de-açúcar e pastagem, os quais ocupam extensas áreas do estado de São Paulo (MANZATTO et al., 2009).

Para alcançar o objetivo principal, foram traçados os seguintes objetivos específicos:

(1) avaliar, nos solos das três áreas, a variação dos fluxos de $\mathrm{N}_{2} \mathrm{O}$ em função do conteúdo de água, comparando amostras mantidas com a umidade original com amostras em que a umidade foi ajustada para atingir 60 e $90 \%$ da capacidade de campo (CC);

(2) verificar se os solos diferem com relação à estrutura de suas comunidades bacterianas e abundância dos genes $16 \mathrm{~S}$ rRNA nirK, cnorB e nosZ, e monitorar as alterações que sofrem em decorrência da mudança do teor de umidade.

(3) averiguar se existem correlações entre os fluxos do GEE, o número de cópias de genes funcionais, a umidade e as características físico-químicas dos solos. 


\section{REVISÃO DE LITERATURA}

\subsection{O processo de desnitrificação e as bactérias desnitrificantes}

A desnitrificação é um importante componente do ciclo biogeoquímico do $\mathrm{N}$, pois devolve esse elemento à atmosfera sob a forma de $\mathrm{N}_{2}$, disponibilizando-o para ser novamente fixado (SCHLESINGER, 1997). Ela pode ser caracterizada como uma via que envolve quatro etapas: redução do $\mathrm{NO}_{3}{ }^{-}$, redução do nitrito $\left(\mathrm{NO}_{2}{ }^{-}\right)$, redução do óxido nítrico (NO) e redução do $\mathrm{N}_{2} \mathrm{O}$ (Figura 1). Tais reações estão interligadas, visto que o produto de uma serve como substrato para a outra, mas são catalisadas por enzimas microbianas que atuam de maneira independente e sequencial (PHILIPPOT, 2002).

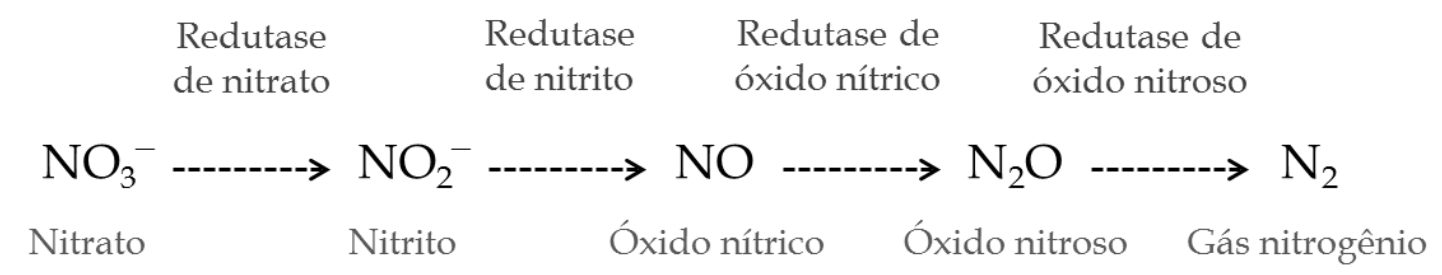

Figura 1 - Representação das etapas do processo de desnitrificação. Com indicação do substrato e produto de cada reação, bem como a enzima responsável por sua catálise

Os organismos que participam desse processo utilizam os íons $\left(\mathrm{NO}_{3}{ }^{-}\right.$ou $\left.\mathrm{NO}_{2}{ }^{-}\right)$ou os óxidos de $\mathrm{N}\left(\mathrm{NO}\right.$ ou $\mathrm{N}_{2} \mathrm{O}$ ) como aceptores finais de elétrons quando o oxigênio se encontra em concentrações muito baixas ou quando está ausente. Como isso leva à produção de ATP, as reações de redução da desnitrificação podem ser consideradas vias alternativas de respiração. Por serem capazes de gerar energia tanto em condições óxicas quanto em condições anóxicas, tais microrganismos são classificados como anaeróbios facultativos (SAGGAR et al., 2013).

A maioria das espécies desnitrificantes não possui o conjunto completo de enzimas necessárias para catalisar todos os passos de redução da via, de modo que devem atuar de maneira integrada para que o $\mathrm{NO}_{3}{ }^{-}$possa ser transformado em $\mathrm{N}_{2}$ (ZUMFT, 1997). O que contribui para que isso aconteça é o fato de que essas redutases podem ser encontradas em diversos microrganismos, os quais estão amplamente distribuídos pelos ambientes. Embora essas enzimas já tenham sido encontradas em fungos e archaeas, o papel mais importante no processo de desnitrificação costuma ser atribuído às bactérias que as sintetizam (PHILLIPOT; HALLIN, 2005). 
As redutases de nitrato podem ser encontradas sob duas formas homólogas, uma ligada à membrana celular (NAR) e outra solúvel, localizada no periplasma (NAP). Vários grupos bacterianos podem sintetizar pelo menos uma dessas enzimas, como é caso de alguns membros dos gêneros Alcaligenes, Bacillus, Citrobacter, Enterobacter, Escherichia, Flavobacterium, Paracoccus, Pseudomonas, Rhodobacter e Streptomyces (CHENEBY et al., 2003). Entretanto, estas duas enzimas também podem ser encontradas em microrganismos que reduzem o $\mathrm{NO}_{3}{ }^{-}$à amônia $\left(\mathrm{NH}_{3}\right)$ e que, portanto, não participam do processo de desnitrificação (PHILIPPOT, 2002).

Os dois tipos de redutase de nitrito (NIR) conhecidos até o momento são evolutivamente independentes. Uma delas contém cobre em seu grupo prostético e a outra um citocromo $c d_{1}$ e são codificadas pelos genes nirK e nirS, respectivamente. O nirS já foi encontrado em bactérias dos gêneros Alcaligenes, Comamonas, Paracoccus, Pseudomonas e Ralstonia. No caso do nirK, podem-se citar os gêneros Alcaligenes, Achromobacter, Blastobacter, Bradyrhizobium, Hyphomicrobium, Nitrosomonas, Nitrosospira, Pseudomonas, Rhizobium e Rhodobacter (THROBÄCK et al., 2004)

As redutases de óxido nítrico (NOR) podem aparecer sob duas formas em bactérias, uma que se utiliza do citocromo $c$ como doador de elétron (cNOR) e outra que emprega quinol (qNOR). Acredita-se que a cNOR esteja estritamente vinculada à desnitrificação, enquanto a qNOR já foi detectada em microrganismos não-desnitrificantes, desempenhando aparentemente uma função de desintoxicação contra o NO exógeno (RICHARDSON, 2000). O gene que codifica a subunidade catalítica da cNOR (o cnorB) já foi encontrado em bactérias de diversos gêneros como Alcaligenes, Bosea, Bradyrhizobium, Ensifer, Pseudomonas, Paracoccus e Rhodobacter. Essa enzima se destaca por ser capaz de formar ligações entre dois átomos de $\mathrm{N}$ (conforme pode ser observado na molécula de $\mathrm{N}_{2} \mathrm{O}$ ), desempenhando um papel único na via de desnitrificação (BRAKER; TIEDJE, 2003).

A redutase de óxido nitroso (NOS) existe sob uma única forma na natureza e é responsável por reduzir o $\mathrm{N}_{2} \mathrm{O}$ a $\mathrm{N}_{2}$, que é um gás relativamente inerte (BURGER; MATIASEK, 2009). Dessa forma, os organismos que possuem essa enzima podem afetar diretamente a concentração desse GEE na atmosfera e contribuir para sua diminuição. Uma das subunidades dessa enzima é codificada pelo gene nos $Z$, o qual já foi detectado nos genomas de espécies de Achromobacter, Alcaligenes, Bradyrhizobium, Escherichia, Hyphomicrobium, Pseudomonas, Rhizobium e Sinorhizobium (HENRY et al., 2006). 
As bactérias desnitrificantes podem ser encontradas nos mais variados tipos de solo. Entretanto, elas não costumam se mostrar dominantes do ponto de vista numérico e estima-se que representem entre $0,5 \%$ e $5 \%$ da comunidade bacteriana total. Como constituem um grupo filogeneticamente diverso, a composição das comunidades que estabelecem pode variar consideravelmente de um ambiente para outro, pois será formada pelos taxa que melhor se adaptarem às condições oferecidas (TIEDJE, 1988).

As taxas de desnitrificação podem variar de acordo com a composição da comunidade desnitrificante, mas também dependem de interações complexas entre estes organismos e outros fatores do solo, os quais podem influenciar a atividade de suas enzimas.

\subsection{Efeito das variáveis ambientais sobre o processo de desnitrificação}

Os fatores ambientais que podem afetar a desnitrificação costumam ser categorizados como reguladores proximais ou distais do processo (Figura 2). Os reguladores proximais são aqueles que afetam imediatamente as comunidades desnitrificantes, provocando mudanças instantâneas nas taxas de desnitrificação. Os reguladores distais, por outro lado, controlam a composição e diversidade dessas comunidades, atuando em escalas temporais maiores que os proximais (WALLENSTEIN et al., 2006).

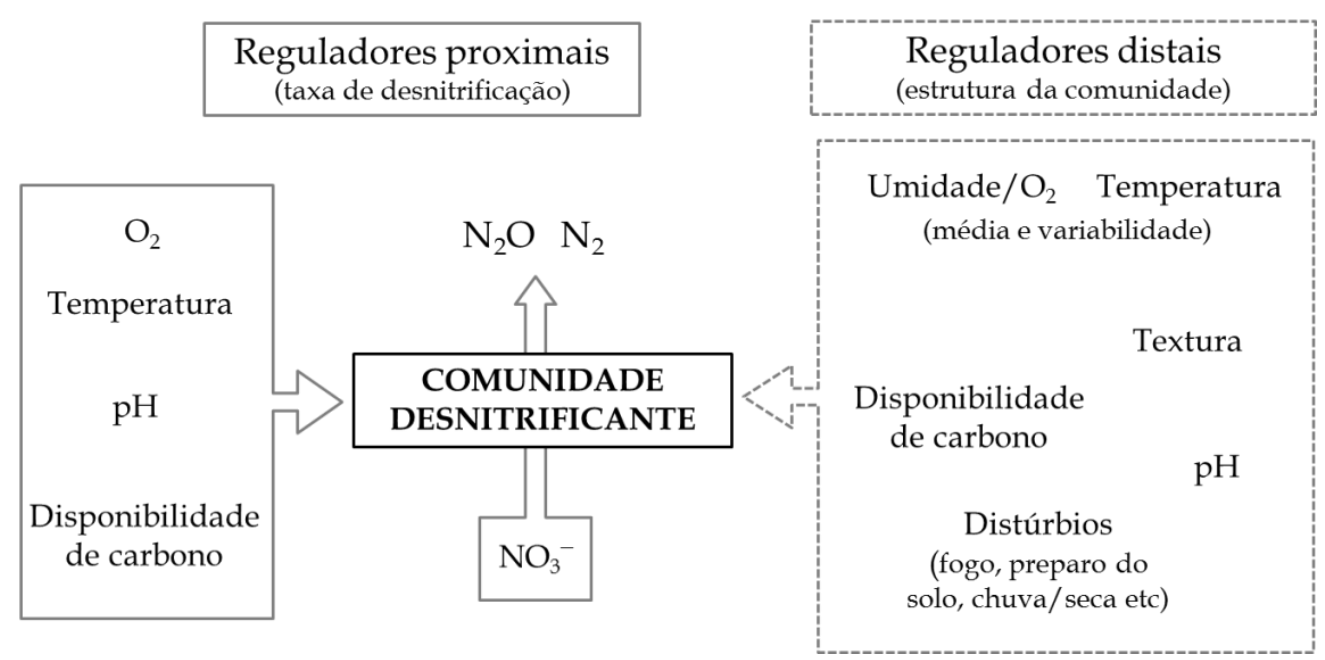

Figura 2 - Reguladores proximais e distais do processo de desnitrificação. Os reguladores distais são responsáveis por moldar as comunidades desnitrificantes e atuam em longo prazo. Os controles proximais influenciam a atividade destes microrganismos e, portanto, são capazes de alterar instantaneamente as taxas de desnitrificação, qualquer que seja a comunidade (adaptado de Wallenstein et al., 2006) 
Dentre os reguladores proximais mais importantes da desnitrificação está a disponibilidade de $\mathrm{O}_{2}$. A depleção desse gás faz com que a síntese das redutases microbianas envolvidas no processo seja ativada em questão de horas; porém, quando a concentração do mesmo aumenta, a transcrição dos genes que as codificam é prontamente bloqueada (VAN SPANNING; RICHARDSON; FERGUSON, 2007).

Em solos aerados, a ocorrência da desnitrificação se restringe a áreas localizadas capazes de suportar a atividade microbiana anaeróbia, como no interior de microagregados (TIEDJE et al., 1984). À medida que a água preenche o espaço poroso do solo e faz com que o mesmo se torne mais pobre em $\mathrm{O}_{2}$, as taxas de desnitrificação aumentam e maiores quantidades dos gases produzidos durante esse processo passam a ser liberadas na atmosfera (HOLTAN-HARTWIG; DORSCH; BAKKEN, 2000).

As proporções com que o $\mathrm{NO}, \mathrm{N}_{2} \mathrm{O}$ e $\mathrm{N}_{2}$ são emitidos via desnitrificação dependem da capacidade que cada comunidade tem de produzi-los (CAVIGELLI; ROBERTSON, 2000; MORLEY et al., 2008). De maneira geral, a quantidade de $\mathrm{N}_{2} \mathrm{O}$ liberada por estes organismos em relação aos outros gases costuma aumentar conforme aumenta o teor de umidade do solo (DAVIDSON, 1992; RUDAZ et al., 1999). No entanto, essa resposta da comunidade desnitrificante à anaerobiose pode variar entre um ambiente e outro devido a diferenças com relação a outros fatores capazes de determinar sua atividade.

Assim como a umidade, a disponibilidade de amônio $\left(\mathrm{NH}_{4}{ }^{+}\right)$, de $\mathrm{NO}_{3}{ }^{-}$e de carbono (C), a temperatura e o pH também são importantes reguladores proximais da desnitrificação, pois exercem uma influência direta sobre a ação das enzimas que catalisam as etapas de redução do processo (THOMAS; LLOYD; BODDY, 1994; WEIER et al., 1993) . De modo geral, a atividade desnitrificante é estimulada em solos neutros ou levemente básicos, com maiores quantidades de $\mathrm{C}$ e de $\mathrm{N}$ mineral e que apresentam temperaturas mais elevadas (SAGGAR et al., 2009).

O tipo de cobertura vegetal e a textura do solo, o clima, a disponibilidade de recursos e as práticas de manejo, podem ser citados como exemplos de reguladores distais da desnitrificação, visto que influenciam a composição das comunidades desnitrificantes. Além disso, a exposição prolongada das mesmas aos fatores que atuam como reguladores proximais e às variações temporais que eles sofrem pode afetar sua estruturação, de modo que eles também contribuem com a regulação distal do processo (DE KLEIN; VAN LOGTESTIJN, 1996; GROFFMAN; TIEDJE, 1989; TIEDJE, 1988). 
Embora diversos trabalhos experimentais tenham levado a generalizações a respeito dos efeitos dos reguladores proximais e distais sobre o processo de desnitrificação e sobre as taxas de produção do $\mathrm{N}_{2} \mathrm{O}$, o modo como esses fatores individuais interagem para afetar sua dinâmica e os fluxos desse GEE ainda permanece mal compreendido (SAGGAR et al., 2013).

\subsection{Experimentos em condições controladas}

Elucidar o papel dos fatores ambientais no controle da estrutura e atividade da comunidade desnitrificante não é uma tarefa simples quando se dispõe apenas de dados obtidos em campo. Os principais problemas, nesse caso, se devem ao fato de que as variáveis ambientais flutuam livremente na natureza e muitas delas o fazem de maneira simultânea, de modo que é difícil definir os efeitos isolados que as mesmas exercem sobre a microbiota (WALLENSTEIN et al., 2006).

Para contornar os problemas associados às variações temporais e espaciais das condições ambientais, muitos estudos têm sido realizados em laboratório, sob condições controladas. Por permitirem criar um meio mais estável, são importantes ferramentas para elucidar como grupos microbianos específicos respondem às mudanças no meio em que se encontram (ELLER; KRÜGER; FRENZEL, 2005).

Como os processos microbianos que ocorrem na natureza podem ser reproduzidos em menor escala, muitas pesquisas realizadas com o objetivo de elucidar os mecanismos através dos quais os reguladores do processo de desnitrificação atuam sobre os organismos envolvidos no mesmo vêm sendo realizadas através de experimentos de microcosmos (BARTON et al., 2013; HARTER et al., 2013; HENDERSON et al., 2010; SZUKICS et al., 2010).

Os microcosmos experimentais permitem avaliar melhor o efeito de diferentes tratamentos, pois devido às suas dimensões reduzidas, podem ser produzidos em maiores quantidades, garantindo um número adequado de repetições (ELLER; KRÜGER; FRENZEL, 2005). Além disso, podem ser facilmente armazenados em estufas, incubadoras e salas climatizadas, ou seja, em locais em que é possível manter as condições estáveis. Dessa forma, são ideais para testar o efeito de vários níveis de um fator de interesse (como diferentes teores de umidade) de maneira simultânea em amostras ambientais distintas. 


\subsection{Uso de técnicas moleculares em Ecologia Microbiana}

A Ecologia Microbiana é o ramo da ciência voltado para o estudo das interações que os microrganismos estabelecem entre si e com o meio em que se encontram. Compreender essas relações permite identificar quais são os fatores bióticos e abióticos que determinam sua distribuição, abundância e atividade. Durante muito tempo, as pesquisas nessa área foram feitas por meio de técnicas baseadas no cultivo e isolamento de microrganismos. Atualmente, no entanto, sabe-se que estas apresentam limitações.

Alguns autores sugerem que $99 \%$ das bactérias presentes no solo não podem ser cultivadas através dos métodos convencionalmente utilizados em laboratório e que, portanto, essa pequena fração cultivável não representa a vasta diversidade de grupos taxonômicos presentes na comunidade total (TORSVIK et al., 1998). A necessidade de técnicas mais confiáveis e precisas para estudar a microbiota deste e de outros ambientes impulsionou o desenvolvimento de abordagens independentes de cultivo.

Nesse contexto, o uso de técnicas baseadas na análise do DNA microbiano extraído diretamente de amostras ambientais tem possibilitado uma análise mais abrangente dos microrganismos e uma caracterização mais fiel das comunidades que constituem (HUGHES et al., 2001), além de uma melhor compreensão acerca do comportamento de grupos microbianos específicos (KIRK et al., 2004). Estudar o DNA ficou mais prático após a invenção da Reação em Cadeia da Polimerase (PCR, do inglês Polymerase Chain Reaction), a qual permite multiplicar um determinado segmento de DNA milhares de vezes em poucas horas, mesmo que este esteja presente em meio a um complexo material genético (MULLIS, 1990).

O estudo das comunidades bacterianas geralmente se inicia com a amplificação do gene que codifica o $16 \mathrm{~S}$ rRNA. Esse está presente em todos os organismos e sua sequência apresenta regiões específicas que são altamente conservadas entre os organismos pertencentes a um mesmo gênero ou espécie, mas que variam entre aqueles que pertencem a taxa distintos. Assim, analisar as sequências de 16S rRNA das bactérias presentes numa determinada amostra permite ter uma ideia sobre a composição e estruturação da comunidade estabelecida na mesma (KIRK et al., 2004).

Quando se tem por objetivo estudar grupos microbianos responsáveis por realizar um determinado processo, com é o caso dos organismos desnitrificantes, torna-se pouco prático analisar as sequências de 16S rRNA da comunidade bacteriana total. Em decorrência disso, 
são mais comumente analisados através de genes que os diferenciam de outros microrganismos, como aqueles que codificam as enzimas associadas ao processo de desnitrificação (PHILIPPOT, 2002).

\subsubsection{T-RFLP (Terminal Restriction Fragment Length Polymorphism)}

A análise de T-RFLP tem se mostrado uma ferramenta muito útil para o estudo da diversidade microbiana nos mais diversos tipos de amostras como solos, sedimentos, plantas etc. (THIES, 2007). Os passos necessários para realizar essa análise estão ilustrados na Figura 3.

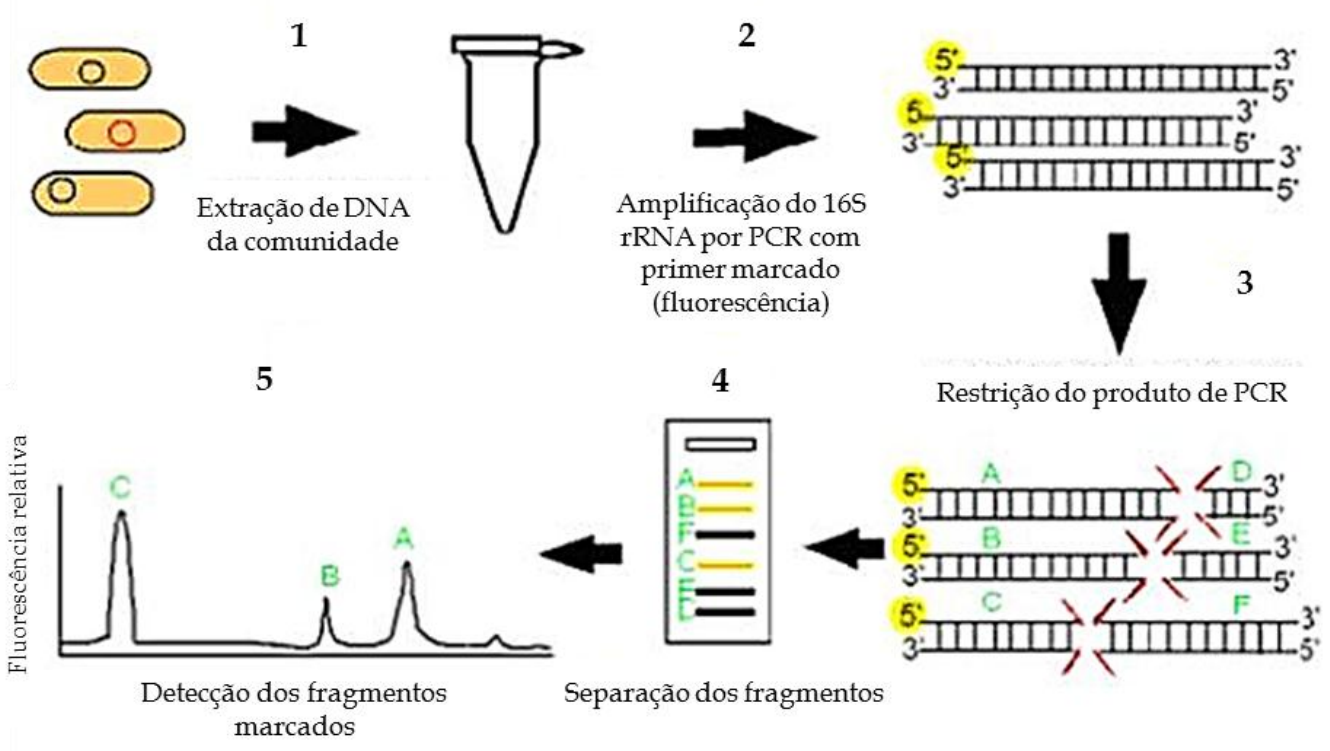

Figura 3 - A análise de T-RFLP e todos os passos necessários para a obtenção dos resultados. (1) O DNA microbiano é extraído da amostra de interesse; (2) o gene de interesse é amplificado através de uma reação de PCR, feita com um primer marcado com fluorescência; (3) restrição dos produtos amplificados com endonucleases, gerando fragmentos de diferentes tamanhos de acordo com a posição do sítio de reconhecimento da enzima na sequência; (4) separação dos fragmentos de diferentes tamanhos por eletroforese; (5) detecção dos fragmentos que tem seu tamanho e nível de fluorescência determinados e conversão dos dados coletados em um eletroferograma (adaptado de Grüntzig et al, 2002)

O estudo das populações bacterianas por T-RFLP baseia-se na detecção de polimorfismos na sequência do gene 16S rRNA (LIU et al., 1997). O primeiro passo para essa análise é utilizar o DNA microbiano extraído da amostra ambiental a ser estudada como molde em uma reação de PCR. Nesse caso, devem ser empregados primers "universais", isto 
é, capazes de amplificar o gene da maioria das bactérias conhecidas. Pelo menos um desses primers deve ser marcado com um corante fluorescente, como a 6-carboxifluoresceína (6-FAM).

Os amplicons gerados devem ser submetidos a uma reação de restrição enzimática, na qual se utiliza uma endonuclease capaz de clivar as sequências sempre que detecta um sítio de reconhecimento. Normalmente, são utilizadas enzimas que têm sítios de reconhecimento de quatro pares de bases, porque sequências curtas se repetem com maior frequência nos genomas do que as mais extensas (KIRK et al., 2004). Isso aumenta as chances de os amplicons serem clivados e permite diferenciar melhor as comunidades. Além disso, costumase usar mais do que uma enzima de restrição (LIU et al., 1997;. MARSH, 1999), o que permite uma análise com melhor resolução já que o produto amplificado que não é clivado por uma endonuclease pode ser clivado pelas demais (MARSH et al., 2000).

Após a restrição, os fragmentos gerados são separados por eletroforese e somente aqueles correspondentes às extremidades que contêm o primer marcado com fluorescência os chamados fragmentos terminais de restrição (T-RF's) - são passíveis de detecção. Essa é feita com o auxílio de um sequenciador automático dotado de um detector a laser, que determina o tamanho e a abundância (proporcional ao sinal de fluorescência) de cada T-RF. Essas informações são convertidas em um eletroferograma, no qual T-RF's de diferentes comprimentos são representados por diferentes picos e a altura de cada um, medida em unidades de fluorescência, é proporcional à quantidade com que o mesmo aparece na amostra (LIU et al., 1997).

As diferenças nos comprimentos dos T-RF's refletem a existência de sequências de 16S rRNA distintas, com sítios de reconhecimento localizados em diferentes posições ao longo do gene. Todavia, diferentes populações podem compartilhar T-RF's de mesmo comprimento e não se pode afirmar que cada T-RF equivale a uma espécie bacteriana. Admite-se, então, que eles representam unidades taxonômicas operacionais (UTO's) (TIEDJE et al., 1999). Através da análise dos perfis de T-RFLP é possível medir a riqueza de UTO's e a abundância de cada uma delas em uma comunidade. Quando feita de maneira comparativa, permite identificar semelhanças e diferenças entre as comunidades de amostras distintas (LIU et al., 1997).

Além de apresentar a vantagem de ser um procedimento automatizado, o que possibilita trabalhar com um grande número de amostras ambientais, a análise de T-RFLP possui uma alta reprodutibilidade. Em decorrência disso, é uma técnica confiável e capaz de gerar grande 
quantidade de informações relevantes em um período de tempo relativamente curto (OSBORN; MOORE; TIMMIS, 2000).

Os resultados da análise de T-RFLP podem ser usados para avaliar as alterações que ocorrem nas comunidades bacterianas em resposta às mudanças nas condições do ambiente na qual estão estabelecidas, monitorando o ganho ou perda de T-RF's específicos pelos perfis que as representam (FRANKLIN; MILLS, 2003). Tais perfis, mesmo que em grande número, podem ser mais facilmente comparados quando se utiliza o tipo apropriado de análise estatística.

A Análise de Componentes Principais (PCA) é um método extremamente útil para detectar semelhanças e diferenças entre perfis de T-RFLP de Bacteria. Trata-se de um modo de reduzir a dimensionalidade dos dados (elevada nesse caso, pois cada T-RF representa uma variável), que passam a ser representados graficamente em duas ou três dimensões. A PCA se utiliza de um conjunto de novas variáveis (combinações lineares das originais) para descrever a maior parte possível da variação dos dados. O primeiro componente principal (PC1) é a primeira nova variável, que incorpora a maior quantidade de variação dos dados. O segundo componente principal (PC2), que é ortogonal ao PC1, leva em consideração a segunda maior parte da variação (JOHNSON, 1998).

\subsubsection{PCR quantitativo em tempo real}

A técnica de PCR quantitativo em tempo real (qPCR) permite realizar a quantificação precisa de sequências de interesse em amostras ambientais (HIGUCHI et al., 1993). Diversos trabalhos têm empregado a qPCR com o objetivo de determinar o número de cópias dos genes narG, nirK, norB e nosZ em amostras de solo (DANDIE et al., 2007; HENRY et al., 2006; KANDELER et al., 2006; WALLENSTEIN; VILGALYS, 2005) e também para monitorar como a abundância desses genes varia em função de fatores como, por exemplo, a disponibilidade de diferentes fontes de $\mathrm{C}$, a temperatura, a umidade e o $\mathrm{pH}$ (HENDERSON et al., 2010; SZUKICS et al., 2010; BARTON et al., 2013).

A qPCR é considerada uma evolução da PCR convencional. A principal diferença entre ambas reside no fato de que, enquanto no método tradicional a quantidade de produto gerado é medida apenas ao final da reação, a qPCR permite monitorar o número de cópias de amplicons que vão se formando à medida que a reação ocorre. Acompanhar o processo de amplificação em tempo real só é possível devido à emissão de fluorescência, a qual é proporcional à quantidade de produtos formados e vai sendo registrada ao longo de todo o 
processo (HIGUCHI et al., 1992). Para isso, utilizam-se sondas contendo fluoróforos ou corantes que se ligam a dupla fita do DNA em formação, termocicladores com sistema ótico para capturar a fluorescência e computadores com softwares capazes de capturar os dados e realizar a análise ao final da reação (NOVAIS; PIRES-ALVES; SILVA, 2004).

Nos primeiros ciclos da reação de qPCR, quando a quantidade de produto amplificado ainda é pequena, o nível de fluorescência emitido pelos mesmos é baixo. A fluorescência só é considerada significativa quando, após começar a aumentar de maneira exponencial, ela consegue ultrapassar um limiar (threshold) pré-determinado. Abaixo disso, considera-se que os sinais detectados provêm de ruídos de fundo da técnica, os quais provavelmente equivalem aos níveis de fluorescência mais baixos que são continuamente emitidos pelos reagentes utilizados (HIGUCHI et al., 1993).

O ciclo em que o nível de fluorescência ultrapassa o threshold $(\mathrm{Ct})$ é o parâmetro mais importante para a qPCR. Isso porque a quantidade inicial do DNA alvo é inversamente proporcional ao mesmo, ou seja, quanto maior a abundância do gene submetido à amplificação na amostra, mais cedo o produto acumulado é detectado e menor é o valor do Ct. Comparando o valor de $\mathrm{Ct}$ da amostra de interesse com os valores de $\mathrm{Ct}$ de amostras contendo quantidades conhecidas do mesmo gene (padrões externos), é possível determinar o número de cópias presente inicialmente na mesma (NOVAIS; PIRES-ALVES; SILVA, 2004).

O padrão externo ideal contém sequências idênticas ou que variam sutilmente com relação à sequência alvo. Uma curva-padrão de diluições do mesmo pode ser construída e utilizada para determinar as concentrações em que o gene de interesse aparece nas amostras (RUTLEDGE; COTE, 2003). Além de ser importante para a quantificação em si, a curvapadrão é utilizada pelo software de análise para calcular a eficiência da reação, que equivale a $100 \%$ se o número de amplicons dobra a cada ciclo (SAIKI et al., 1988), e o coeficiente de correlação, que revela quão bem os dados se ajustaram à curva, indicando a precisão da pipetagem (RUTLEDGE; COTE, 2003).

O uso de corantes fluorescentes em qPCR é bastante difundido e, em geral, utilizam-se os do tipo SYBR ${ }^{\circledR}$ Green. Ao contrário das sondas, que se ligam exatamente ao gene de interesse, essas substâncias podem se ligar a qualquer DNA de fita dupla gerado durante a amplificação. Embora a ligação que se estabelece seja muito forte, ela é reversível e se desfaz quando a molécula se desnatura. Sendo assim, a fluorescência deve ser registrada logo após o final da etapa de elongação. Fazendo isso a cada ciclo da reação, é possível monitorar a quantidade de produto que vai se formando (KUBISTA et al., 2006). 
Devido ao fato de os corantes fluorescentes se ligarem a qualquer dupla fita presente na solução, diz-se que esse método é pouco específico. Caso outro produto seja amplificado durante a reação, ele também será uma fonte de DNA dupla fita que contribuirá para aumentar o sinal de fluorescência. Para assegurar que somente o segmento de interesse está sendo formado e quantificado, curvas de dissociação (melting) são construídas ao final de cada reação (KUBISTA et al., 2006).

Diferentes moléculas de dupla fita se dissociam a diferentes temperaturas. Isso depende de diversos fatores como o conteúdo de guanina e citosina, tamanho do amplicon, estruturas secundárias e terciárias etc. Para construir as curvas de dissociação, basta expor os produtos amplificados a temperaturas progressivamente maiores e monitorar a fluorescência emitida. $\mathrm{O}$ ponto (temperatura) em que se dissociam corresponde ao momento em que a intensidade da fluorescência decai abruptamente. Se esse decaimento ocorrer em mais de uma etapa, significa que há mais de um tipo de molécula na reação (RIRIE; RASMUSSEN; WITTWER, 1997). Nesse caso, a curva de melting derivativa exibirá mais de um pico.

Essa técnica apresenta muito mais sensibilidade e maior reprodutibilidade que a PCR convencional. Ela tem se mostrado adequada para estudos que requerem a análise de um grande número de amostras, visto que assegura uma detecção rápida e não requer investimentos elevados (HARMS et al., 2003). 


\section{MATERIAL E MÉTODOS}

\subsection{Coleta das amostras de solo}

As amostras de solo utilizadas no experimento foram coletadas em outubro de 2012 na Fazenda Capuava, situada em Piracicaba (SP). Este município apresenta uma altitude média de $554 \mathrm{~m}$ e médias anuais de temperatura e precipitação de $22^{\circ} \mathrm{C}$ e $1330 \mathrm{~mm}$, respectivamente (MIRANDA et al., 2011) Segundo a classificação de Köppen, o clima da região é do tipo Cwa, subtropical úmido com estiagem no inverno (com temperatura média do mês mais quente acima de $22^{\circ} \mathrm{C}$ e temperatura média do mês mais frio inferior a $18^{\circ} \mathrm{C}$ ).

As coletas foram realizadas em três áreas da fazenda: (1) área cultivada com cana-de-

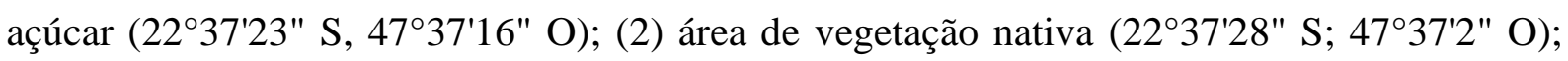
(3) área de pastagem (22³6'59" S; 47³6'16" O) (Figura 4).

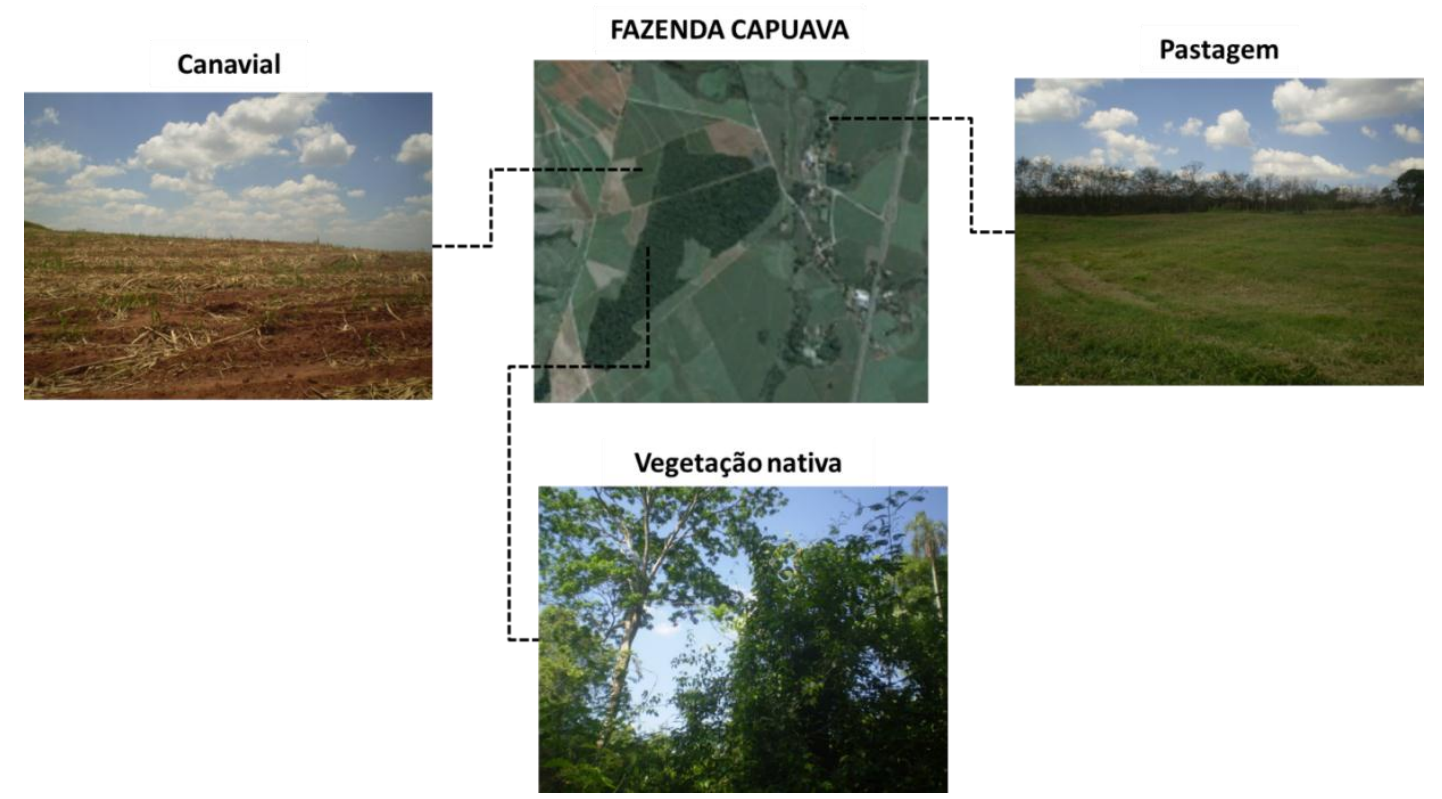

Figura 4 - Vista aérea da Fazenda Capuava, no município de Piracicaba (SP), com destaque para a localização das áreas de cultivo de cana-de-açúcar, vegetação nativa e pastagem onde as amostras de solo foram coletadas (Fonte da imagem aérea: Google Earth). 
Em cada área, foi delimitada uma parcela de aproximadamente 2 hectares, onde foram coletadas amostras de solo em cinco pontos distribuídos aleatoriamente. Cada um desses pontos era formado por cinco subpontos, sendo a distância mínima entre os mesmos de 1 metro. A coleta nesses subpontos foi realizada com o auxílio de tubos de PVC previamente esterilizados. Estes possuíam $15 \mathrm{~cm}$ de comprimento e $6 \mathrm{~cm}$ de diâmetro e foram introduzidos verticalmente nos solos após a retirada da serapilheira (Figura 5).

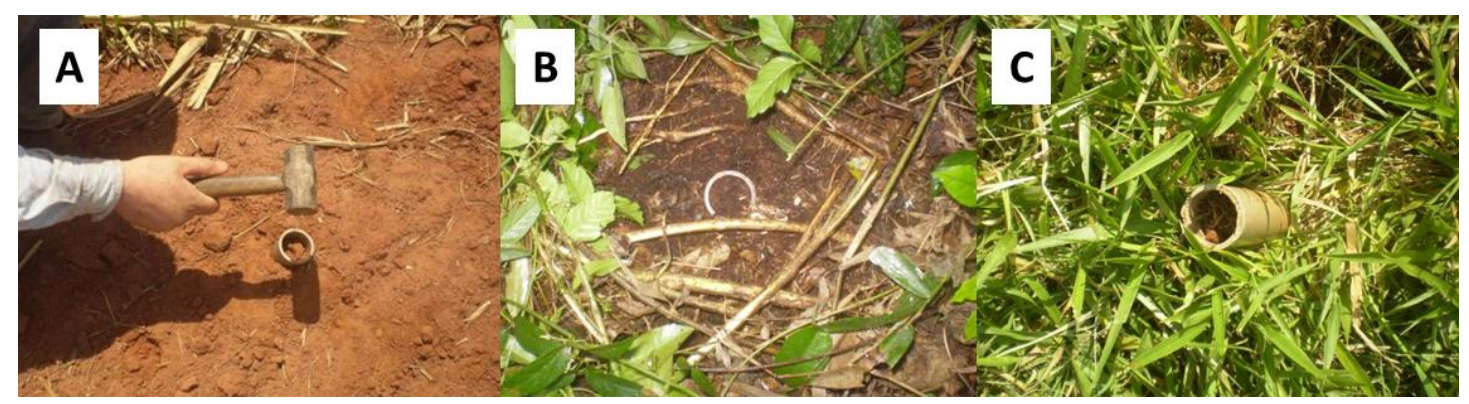

Figura 5 - Coleta de amostras de solo com auxílio de tubos de PVC nas áreas de cultivo de cana-deaçúcar (A), vegetação nativa (B) e pastagem (C)

Os tubos contendo as amostras de solo foram armazenados em sacos plásticos e acondicionados em uma caixa de isopor para evitar alterações na temperatura do material durante o transporte até o Laboratório de Biologia Celular e Molecular (CENA/USP). As amostras permaneceram por cerca de 12 horas em temperatura ambiente $\left(22^{\circ} \mathrm{C}\right)$ até serem processadas para montagem do experimento.

\subsection{Processamento das amostras}

Todas as amostras de solo foram retiradas dos tubos de PVC e peneiradas (malha de 6 $\mathrm{mm}$ ), com a finalidade de remover os materiais indesejáveis que haviam sido coletados acidentalmente: fragmentos grandes de raízes, eventuais restos de serrapilheira, pedras e membros da fauna edáfica (insetos, anelídeos etc.).

Para manter a comunidade microbiana mais representativa da condição original, optouse por não submeter o solo ao processo de secagem, que geralmente é recomendado para facilitar sua passagem pela peneira. Segundo Thomson et al. (2010), quando este procedimento é feito com o solo ainda fresco, a estrutura da comunidade microbiana é afetada em menor extensão do que nos processos que envolvem secagem, peneiramento e reumedecimento. 
Depois de peneiradas, todas as amostras provenientes de uma mesma área de coleta foram misturadas. Assim, foram obtidas três amostras compostas homogêneas para a montagem dos microcosmos experimentais. Antes disso, no entanto, os solos foram analisados quanto aos seus atributos físicos e químicos.

\subsection{Análise das propriedades físico-químicas dos solos}

De cada uma das amostras compostas, três alíquotas de solo (300 g cada) foram coletadas e enviadas ao Laboratório de Análises de Solo da Escola Superior de Agricultura “Luiz de Queiroz" (ESALQ/USP) para determinação dos seguintes atributos: matéria orgânica (MO), teores totais de $\mathrm{N}_{-} \mathrm{NH}_{4}{ }^{+}$e $\mathrm{N}_{-} \mathrm{NO}_{3}{ }^{-}, \mathrm{pH}$, teores de fósforo (P) e de cátions trocáveis $\left(\mathrm{K}^{+}, \mathrm{Ca}^{2+}, \mathrm{Mg}^{2+} \mathrm{e} \mathrm{Al}^{3+}\right)$, acidez potencial $\left(\mathrm{H}^{+}+\mathrm{Al}^{3+}\right)$, capacidade de troca catiônica (CTC), soma de bases (SB), saturação por bases (V) e textura (teores de areia, silte e argila).

Os teores totais de $\mathrm{C}$ e $\mathrm{N}$ foram determinados pelo Laboratório de Biogeoquímica Ambiental (CENA/USP) por combustão a seco no equipamento Carbon Analyser - LECO® CN-2000, conforme descrito por Nelson e Sommers (1982). Nesse caso, o preparo do material foi feito da seguinte maneira: alíquotas de $5 \mathrm{~g}$ de cada amostra composta de solo foram mantidas em estufa a $37{ }^{\circ} \mathrm{C}$ por cinco dias para perda total do conteúdo de água. Após esse período, o material foi moído com auxílio de um almofariz e pistilo de porcelana e passado em peneira de 0,150 $\mathrm{mm}$. Essas determinações também foram realizadas em triplicata.

\subsection{Determinação da umidade dos solos}

A umidade gravimétrica, que expressa qual a porcentagem de uma dada massa de solo que corresponde à água (EMBRAPA, 1979), foi calculada para todas as amostras compostas. De cada uma delas, cinco alíquotas (10 g cada) foram coletadas e dispostas sobre placas de Petri. As placas foram mantidas em estufa a $110^{\circ} \mathrm{C}$ (Figura 6) e a perda de água dos solos contidos nas mesmas foi monitorada diariamente através da sua pesagem.

Quando houve estabilização do peso, considerou-se que toda a água presente no material havia sido eliminada. A massa de solo seco ao final do período de incubação foi registrada e utilizada para calcular a umidade das alíquotas através da seguinte equação (1): 


$$
\mathrm{U} \%=\left[\left(\mathbf{M}_{\mathbf{u}}-\mathbf{M}_{\mathrm{s}}\right) / \mathbf{M}_{\mathrm{s}}\right] \mathbf{x} 100(1)
$$

Onde:

$\mathbf{U} \%$ = umidade gravimétrica;

$\mathbf{M}_{\mathbf{u}}=$ massa de solo úmido $(\mathrm{g})$, antes do processo de secagem;

$\mathbf{M}_{\mathbf{s}}=$ massa de solo seco $(\mathrm{g})$.

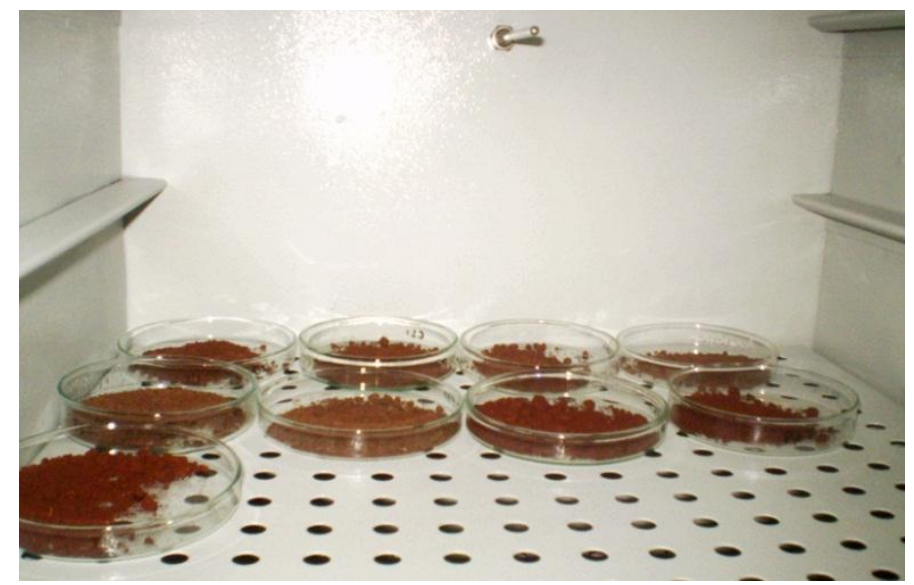

Figura 6 - Secagem de amostras de solo em estufa a $110^{\circ} \mathrm{C}$ para determinação da umidade gravimétrica

A umidade de cada amostra composta de solo foi considerada a média dos valores calculados para as suas respectivas alíquotas.

\subsection{Determinação da umidade dos solos na capacidade de campo}

Para o cálculo da CC, cinco alíquotas (30 g cada) foram retiradas de cada amostra composta de solo e colocadas em funis de plástico de $200 \mathrm{ml}$. Cada funil continha uma pequena quantidade de algodão disposta sobre o orifício inferior, para impedir a passagem do solo, e foi colocado sobre um Erlenmeyer de $250 \mathrm{ml}$ (Figura 7). 


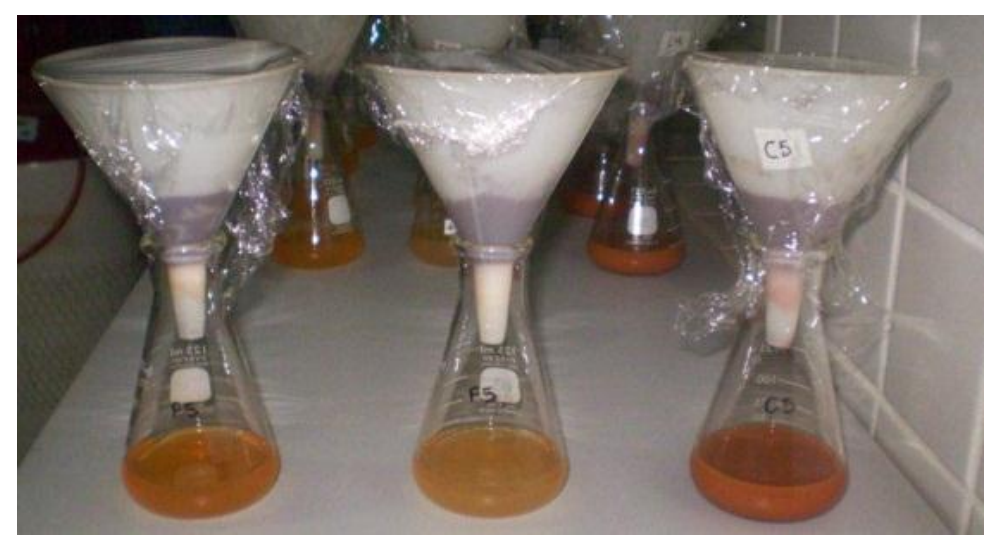

Figura 7 - Sistema para percolação da água através das amostras de solo utilizado para determinação da capacidade de campo

Posteriormente, $50 \mathrm{ml}$ de água deionizada foram acrescentados ao solo e, após sua percolação, determinou-se a quantidade que o mesmo foi capaz de reter. Para tal, utilizou-se o método descrito anteriormente, no qual a umidade da amostra é calculada com base nas massas de solo antes e depois do processo de secagem em estufa. Durante todo o processo, filme e plástico foi utilizado para cobrir os funis e evitar a perda de água pelo solo por evaporação.

Para cada amostra composta de solo, a umidade na CC foi considerada a média dos valores obtidos a partir das cinco alíquotas. Tais valores serviram de base para calcular a quantidade de água necessária para se atingir os níveis de umidade equivalentes a $60 \%$ e 90\% da CC de cada solo.

\subsection{Montagem e condução do experimento de microcosmos}

Os microcosmos foram estabelecidos em frascos de vidro com capacidade para 1,5 L. Em cada frasco foram acondicionados $300 \mathrm{~g}$ de solo de uma das amostras compostas que, depois de 24 horas, receberam diferentes volumes de água - algumas amostras foram mantidas com a umidade original enquanto outras foram ajustadas para 60 e $90 \%$ da umidade na CC. Dessa forma, o experimento consistiu em um ensaio fatorial 3x3 (três amostras de solo combinadas com três teores de umidade) (Tabela 1). 
Tabela 1 - Tratamentos quanto ao tipo de solo utilizado e o teor de umidade com a codificação correspondente

\begin{tabular}{|c|c|c|}
\hline Solo & Umidade & Codificação \\
\hline $\begin{array}{c}\text { Vegetação } \\
\text { nativa }\end{array}$ & $\begin{array}{l}\text { original } \\
60 \% \text { da capacidade de campo } \\
90 \% \text { da capacidade de campo }\end{array}$ & $\begin{array}{l}\mathrm{F}_{\text {original }} \\
\mathrm{F}_{60 \% \mathrm{CC}} \\
\mathrm{F}_{90 \% \mathrm{CC}}\end{array}$ \\
\hline $\begin{array}{c}\text { Cana-de- } \\
\text { açúcar }\end{array}$ & $\begin{array}{l}\text { original } \\
60 \% \text { da capacidade de campo } \\
90 \% \text { da capacidade de campo }\end{array}$ & $\begin{array}{l}\mathrm{C}_{\text {original }} \\
\mathrm{C}_{60 \% \mathrm{CC}} \\
\mathrm{C}_{90 \% \mathrm{CC}}\end{array}$ \\
\hline Pastagem & $\begin{array}{l}\text { original } \\
60 \% \text { da capacidade de campo } \\
90 \% \text { da capacidade de campo }\end{array}$ & $\begin{array}{l}\mathrm{P}_{\text {original }} \\
\mathrm{P}_{60 \% \mathrm{CC}} \\
\mathrm{P}_{90 \% \mathrm{CC}}\end{array}$ \\
\hline
\end{tabular}

O delineamento utilizado foi o de blocos ao acaso com quatro repetições (Figura 8). O experimento foi mantido por 30 dias e a umidade do solo contido nos frascos foi controlada durante todo esse período. A pesagem diária dos mesmos permitiu verificar a massa de água perdida, que foi reposta com auxílio de um borrifador. Neste processo, utilizou-se água deionizada autoclavada e uma espátula previamente esterilizada foi empregada para revolver o solo e garantir uma melhor distribuição da água adicionada.

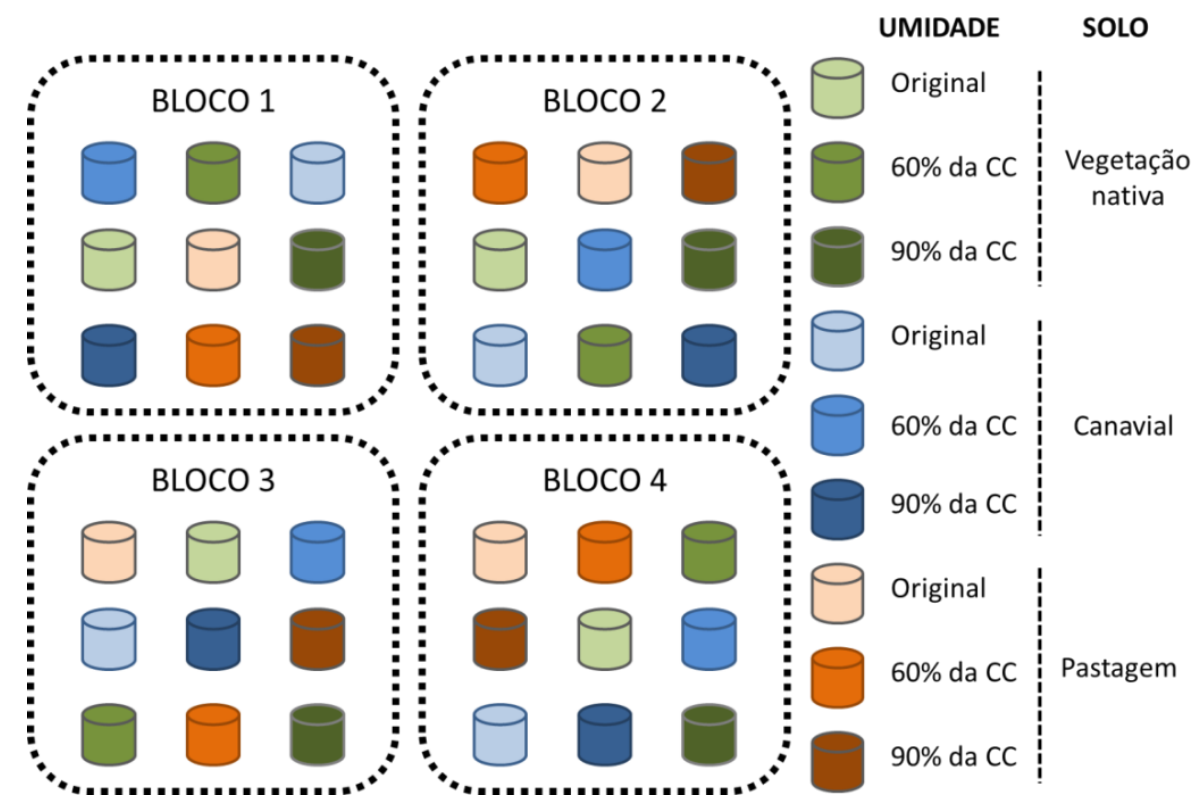

Figura 8 - Croqui do experimento, ilustrando a disposição dos microcosmos submetidos aos diferentes tratamentos em cada bloco experimental. Na legenda, constam as informações sobre a origem do solo utilizado e a umidade sob a qual o mesmo foi mantido 
Os frascos foram mantidos em incubadoras do tipo B.O.D (MA 403, Marconi) a $30{ }^{\circ} \mathrm{C}$, sendo que aqueles pertencentes a um mesmo bloco experimental foram dispostos na mesma prateleira. As tampas dos frascos permaneceram abertas para evitar o acúmulo dos gases produzidos, permitindo que a atmosfera dos mesmos permanecesse em equilíbrio com a do ambiente externo. Estas condições foram mantidas ao longo de todo o período de incubação.

\subsection{Amostragens da atmosfera gasosa e dos solos dos microcosmos}

A primeira coleta da atmosfera e do solo do interior dos frascos foi realizada após 24 horas de incubação, pouco antes de as amostras serem submetidas aos tratamentos (T0). Depois dessa primeira coleta, água deionizada autoclavada foi adicionada aos frascos de acordo com as quantidades calculadas para estabelecer cada tratamento (no caso das amostras mantidas com a umidade original, foi feita somente a reposição da massa de água perdida). As demais coletas foram realizadas 1, 3, 6, 9, 13, 17, 22 e 29 dias após este procedimento.

Imediatamente antes da amostragem, a ventilação dos frascos foi realizada para garantir a dissipação de qualquer gás que eventualmente tivesse se concentrado junto às amostras de solo. Em seguida, os frascos foram hermeticamente fechados e seringas de nylon tipo BD foram utilizadas para a coleta de $20 \mathrm{ml}$ de gás do interior dos mesmos, que pôde ser feita por meio da válvula presente na tampa de cada um (Figura 9). Esta válvula foi fechada logo depois e só foi aberta novamente no momento de realizar as outras coletas, após 5, 10 e 20 minutos. O procedimento foi conduzido em um bloco experimental por vez. Os dados de temperatura e pressão atmosférica foram registrados, visto que os mesmos são requeridos para calcular o fluxo do gás. 


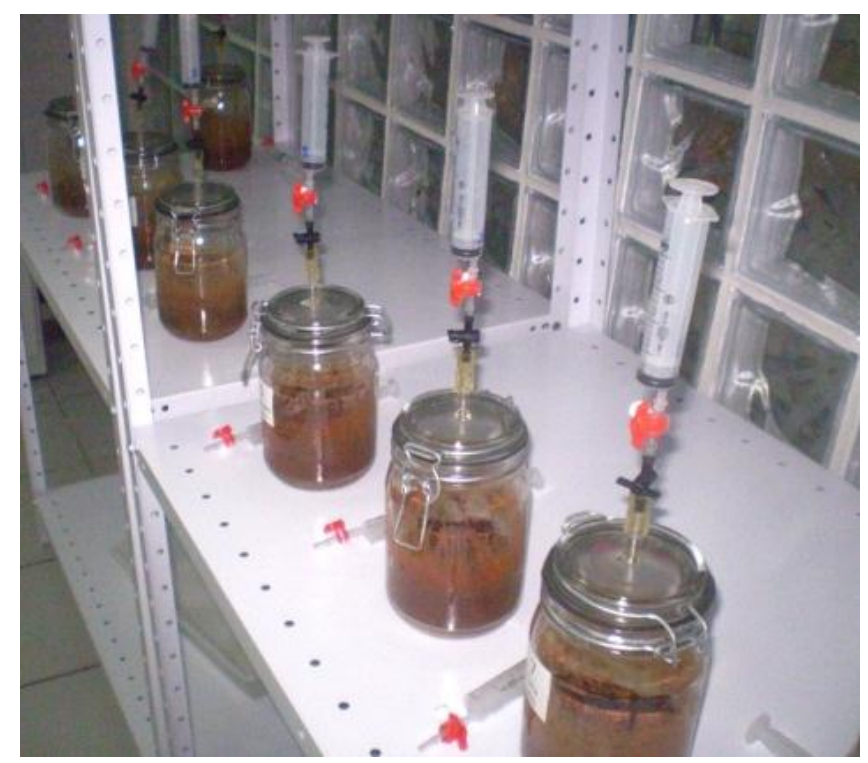

Figura 9 - Procedimento de coleta dos gases contidos na atmosfera do interior dos microcosmos com auxílio de seringas de nylon

Nos dias em que as coletas de gases foram realizadas, amostras dos solos contidos nos microcosmos também foram obtidas para a extração do DNA a ser utilizado nas análises moleculares. Para isso, utilizou-se uma espátula higienizada com etanol $70 \%$ e todas as amostras coletadas foram armazenadas em tubos tipo Eppendorf de $2 \mathrm{ml}$ previamente esterilizados. Estes foram mantidos em ultrafreezer (Glacier Ultra Low Freezer, Nuaire Corporation) a $-80{ }^{\circ} \mathrm{C}$ até o momento da extração.

\subsection{Análise da atmosfera dos microcosmos por cromatografia gasosa e determinação das emissões de $\mathrm{N}_{2} \mathrm{O}$}

A determinação das concentrações de $\mathrm{N}_{2} \mathrm{O}$ nas amostras foi realizada por cromatografia gasosa no Laboratório de Biogeoquímica Ambiental (CENA/USP). O equipamento utilizado foi um Shimadzu GC-2014® e o GEE foi detectado por ECD (Electron Capture Detector). Os fluxos foram calculados pela alteração da concentração do gás no interior dos frascos em função do tempo de incubação, o que foi feito através da análise das amostras obtidas nos diferentes tempos após o fechamento da tampa $(0,5,10$ e $20 \mathrm{~min})$. Os resultados foram corrigidos de acordo com a temperatura e pressão atmosférica no momento da coleta.

As emissões cumulativas de $\mathrm{N}_{2} \mathrm{O}$ foram calculadas pela interpolação linear das emissões médias entre duas mensurações sucessivas e soma dos resultados obtidos ao longo de todo o período de incubação. 


\subsection{Extração de DNA das amostras de solo}

Para as extrações de DNA das amostras de solo, utilizou-se o PowerLyzer PowerSoil DNA Extraction ${ }^{\mathrm{TM}}$ (MoBIO Laboratories, Carlsbad, CA) e as instruções fornecidas pelo fabricante foram seguidas com algumas modificações, conforme descrito a seguir:

De cada amostra, foram adicionados $250 \mathrm{mg}$ de solo em tubo de $2 \mathrm{~mL}$ contendo microesferas de vidro (Glass Tube 0,1 mm). Em seguida, foram pipetados $750 \mu \mathrm{L}$ de Bead Solution e o tubo foi agitado brevemente. Foram acrescentados $60 \mu \mathrm{L}$ da solução $\mathrm{C} 1$, o tubo foi invertido várias vezes e, então, preso ao adaptador do Vortex-Genie 2 (MoBIO Laboratories, Carlsbad, CA) e agitado por 15 min à velocidade máxima. Após a agitação, o tubo foi centrifugado a $10.000 \times \mathrm{g}$ por $3 \mathrm{~min}$. Após essa etapa, $450 \mu \mathrm{L}$ do sobrenadante foram transferidos para um novo tubo, ao qual foram adicionados $250 \mu \mathrm{L}$ da solução C2. Para homogeneização, o tubo foi vortexado por $5 \mathrm{~s}$ e posteriormente incubado a $4^{\circ} \mathrm{C}$ por $5 \mathrm{~min}$. A seguir, centrifugou-se a $10.000 \times$ g por 1 min e $600 \mu \mathrm{L}$ do sobrenadante foram transferidos para um novo tubo. A solução C3 foi adicionada $(200 \mu \mathrm{L})$ com breve agitação e a mistura foi novamente incubada a $4^{\circ} \mathrm{C}$ por 5 min. Logo depois, realizou-se a centrifugação a $10.000 \times \mathrm{g}$ por $1 \mathrm{~min}$ e $750 \mu \mathrm{L}$ do sobrenadante foram transferidos para um novo tubo. Neste, foram colocados $1200 \mu \mathrm{L}$ da solução C4 e procedeu-se uma breve agitação. Após essa etapa, foram carregados $675 \mu \mathrm{L}$ da solução numa coluna com filtro, disposta sobre um novo tubo. $\mathrm{O}$ conjunto foi centrifugado a $10.000 \times \mathrm{g}$ por $1 \mathrm{~min}$, o líquido filtrado pela coluna foi descartado, o restante da solução foi carregado na coluna e o processo foi repetido. Depois, adicionou-se $500 \mu \mathrm{l}$ da solução C5 na coluna e centrifugou-se a $10.000 \times$ g por 30 s. O líquido que passou pelo filtro foi descartado e o tubo foi novamente centrifugado com a coluna vazia por mais $1 \mathrm{~min}$ a $10.000 \times \mathrm{g}$. Após essa etapa, a coluna foi transferida para um novo tubo do kit e foram adicionados $100 \mu \mathrm{l}$ da solução C6 no centro da mesma. Com a centrifugação por 30 s a $10.000 \times$ g foi possível obter, por fim, o DNA da amostra.

Para a confirmação da qualidade da extração, uma alíquota de $5 \mu 1$ do DNA obtido foi submetido à eletroforese em gel de agarose $1 \%(\mathrm{p} / \mathrm{v})$ corado com GelRed ${ }^{\mathrm{TM}}$ (Uniscience) em tampão TSB (BRODY \& KERN, 2004). Como padrão molecular foi utilizado $2 \mu 1$ de Low mass DNA Ladder (Invitrogen Technology). O gel foi submetido a um campo elétrico de $100 \mathrm{~V}$ por aproximadamente $40 \mathrm{~min}$ e, em seguida, foto-documentado.

O DNA extraído foi também quantificado em espectrofotômetro Nanodrop 2000c (Thermocientific), adotando-se a relação de 1,0 de densidade ótica a $260 \mathrm{~nm}\left(\mathrm{DO}_{260}\right)$ como sendo igual a $50 \mathrm{ng}$ de DNA. $\mu \mathrm{L}^{-1}$ (SAMBROOK; FRITSCH; MANIATS, 1989). 


\subsection{Análise de T-RFLP do gene 16S rRNA de Bacteria}

A análise de T-RFLP foi realizada para descrever e comparar as comunidades bacterianas presentes inicialmente nos solos do canavial, pastagem e floresta, avaliando os perfis referentes a cada uma delas nas amostras de solo coletadas antes da aplicação dos tratamentos. Isso foi feito com a finalidade de complementar a caracterização das amostras utilizadas no experimento.

Com o objetivo obter uma visão mais geral do efeito da umidade sobre as comunidades bacterianas nas quais os organismos desnitrificantes estão inseridos, as alterações que as mesmas sofreram após a aplicação dos tratamentos também foram monitoradas com auxílio da análise de T-RFLP.

\subsubsection{Amplificação do gene 16S rRNA de Bacteria}

O gene 16S rRNA bacteriano foi amplificado a partir das amostras de DNA através de reações de PCR feitas com os primers universais fD1 (5' AGAGTTTGATCCTGGCTCAG 3') e rD1 (5' AAGGAGGTGATCCAGCC 3') (WEISBURG et al., 1991). Para que os fragmentos terminais gerados após a restrição desses amplicons pudessem ser detectados pelo sequenciador automático, a extremidade $5^{\text {' }}$ do primer fD1 foi marcada com 6carboxifluoresceína (6-FAM).

Todas as reações foram preparadas em soluções contendo: $3,5 \mu \mathrm{L}$ de tampão para PCR $(10 \times) ; 0,75 \mathrm{mM}$ de $\mathrm{MgCl}_{2} ; 0,5 \mathrm{mM}$ de dNTPs; $0,2 \mu \mathrm{M}$ de cada primer; $1 \%$ de BSA; $1 \mathrm{U}$ de Platinum ${ }^{\circledR}$ Taq DNA Polimerase (Invitrogen); $1 \mu \mathrm{L}$ do DNA extraído e água ultrapura (Milli-Q) esterilizada para um volume final de $35 \mu \mathrm{L}$. As condições utilizadas para a amplificação, todas realizadas em termociclador modelo GeneAmp PCR System 9700 (Applied Biosystems), foram de: $94{ }^{\circ} \mathrm{C}$ por $3 \mathrm{~min}, 35$ ciclos de $94{ }^{\circ} \mathrm{C}$ por $30 \mathrm{~s}, 59{ }^{\circ} \mathrm{C}$ por 45 s e $72{ }^{\circ} \mathrm{C}$ por $1 \mathrm{~min}$; e extensão final de $72^{\circ} \mathrm{C}$ por 15 min.

Para verificar a eficiência e a especificidade da reação, uma alíquota de $5 \mu 1$ do produto de amplificação foi analisada em gel de agarose $1 \%(\mathrm{p} / \mathrm{v})$ corado com GelRed ${ }^{\mathrm{TM}}$ (Uniscience) em tampão TSB (BRODY; KERN, 2004). Como padrão molecular, $2 \mu 1$ de 100pb DNA Ladder (Invitrogen Technology) foram utilizados. O gel foi submetido a um campo elétrico de $100 \mathrm{~V}$ por aproximadamente $40 \mathrm{~min}$ e foto-documentado. 


\subsubsection{Purificação dos produtos de PCR}

Para a purificação dos produtos de PCR, foi utilizado o Kit GFX ${ }^{\mathrm{TM}} P C R D N A$ and Gel Band Purification (GE Healthcare), seguindo as instruções do fabricante:

Aos $30 \mu \mathrm{l}$ restantes de produto da reação de PCR foram adicionados $150 \mu \mathrm{l}$ de Capture Buffer Type 3. Essa mistura foi homogeneizada, carregada em uma coluna GFX (com filtro) encaixada num tubo tipo Eppendorf e centrifugada a $16.000 \times \mathrm{g}$ por $30 \mathrm{~s}$. O líquido filtrado foi descartado e foram adicionados $500 \mu \mathrm{l}$ de Wash Buffer Type 1 na coluna GFX. Em seguida, os tubos foram centrifugados a $16.000 \times \mathrm{g}$ por $30 \mathrm{~s}$ e o líquido filtrado foi descartado. O processo de centrifugação foi repetido para remover totalmente a solução e, a após essa etapa, a coluna foi transferida para um novo tubo de $1,5 \mathrm{ml}$. Foram adicionados $20 \mu \mathrm{l}$ do Elution Buffer Type 4 no centro da coluna de filtro, a qual foi mantida por 1 min à temperatura ambiente. Por fim, realizou-se a centrifugação a $16.000 \times$ g por 1 min e o produto purificado foi obtido.

Uma alíquota de $3 \mu 1$ do material resultante desse processo foi analisada em gel de agarose $1 \%(\mathrm{p} / \mathrm{v})$ corado com GelRed ${ }^{\mathrm{TM}}$ (Uniscience) em tampão TSB (BRODY; KERN, 2004). Como padrão molecular, utilizou-se o 100pb DNA Ladder (Invitrogen Technology). O gel foi submetido a um campo elétrico de $100 \mathrm{~V}$ por aproximadamente $20 \mathrm{~min}$ e fotodocumentado.

\subsubsection{Reação de restrição dos produtos de PCR purificados}

Os produtos de PCR purificados foram utilizados nas reações de restrição (digestão) com as endonucleases $H h a \mathrm{I}\left(\mathrm{GCG}^{\wedge} \mathrm{C}\right)$ e $M s p \mathrm{I}\left(\mathrm{C}^{\wedge} \mathrm{CGG}\right)$, as quais são reconhecidas por permitirem distinguir as comunidades bacterianas de maneira eficaz por meio da técnica de T-RFLP (MARSH et al., 2000).

As reações foram preparadas em soluções contendo 1,5 $\mu$ l de Buffer Tango $(10 \times) ; 1 \%$ de BSA; 0,06 U de endonuclease (Thermo Scientific); $5 \mu \mathrm{L}$ do produto de PCR purificado e água ultrapura (Milli-Q) esterilizada para atingir para um volume final de $15 \mu \mathrm{L}$. As reações foram realizadas em termociclador GeneAmp PCR System 9700 (Applied Biosystems) nas condições: $37^{\circ} \mathrm{C}$ por $3 \mathrm{~h}$ e $68^{\circ} \mathrm{C}$ por 10 min para inativação das enzimas. 


\subsubsection{Precipitação dos produtos de restrição}

Para a precipitação dos fragmentos gerados pela reação de restrição, foram adicionados $2 \mu 1$ de tampão Acetato de Sódio/EDTA e $60 \mu \mathrm{l}$ de etanol absoluto a $15 \mu \mathrm{l}$ do produto da mesma. A mistura foi agitada levemente no vórtex e centrifugada por $45 \mathrm{~min}$ a $2.000 \times \mathrm{g}$, a 10 ${ }^{\circ} \mathrm{C}$. O sobrenadante foi descartado e, em seguida, foram adicionados às amostras $150 \mu \mathrm{lde}$ etanol $70 \%$. Foi realizada uma nova centrifugação a $2.000 \times$ g por $15 \mathrm{~min}$. O sobrenadante foi eliminado e o precipitado foi seco em concentrador (Concentrador 5301, Eppendorf) a $45^{\circ} \mathrm{C}$, por aproximadamente $10 \mathrm{~min}$. As amostras foram armazenadas a $-20{ }^{\circ} \mathrm{C}$ até o momento de serem analisadas.

\subsubsection{Análise dos fragmentos terminais de restrição}

A separação e detecção dos T-RFs presentes em cada amostra foi feita em sequenciador automático ABI PRISM 3100 Genetic Analyzer (Applied Biosystems). Para isso, os produtos das reações de restrição que haviam sido precipitados foram ressuspendidos em uma mistura contendo 9,75 $\mu 1$ de Formamida HiDi e 0,25 $\mu 1$ de padrão de comprimento GeneScan ${ }^{\mathrm{TM}}-500$ $R O X^{\mathrm{TM}}$ Size Standard (Applied Biosystems). Em seguida, foram desnaturados por 5 min a $95^{\circ} \mathrm{C}$ e resfriados a $0{ }^{\circ} \mathrm{C}$ por 4 min para, então, serem carregados no sequenciador.

Os eletroferogramas gerados foram analisados através do programa Gene Mapper v4.1 (Applied Biosystems). O tamanho e a intensidade de fluorescência dos picos (T-RFs) encontrados nas diferentes amostras foram determinados e a qualidade das corridas foi verificada. Os dados obtidos foram exportados para uma planilha eletrônica no programa Microsoft Excel (Microsoft).

\subsubsection{Processamento dos dados para comparação dos perfis de T-RFLP}

Os T-RFs representados por picos com menos de 50 unidades de fluorescência foram excluídos das análises, sendo considerados ruídos do background provenientes da técnica ao invés de "picos verdadeiros". Os T-RFs menores que 50 pares de base e os maiores que 500 também foram eliminados (CULMAN et al., 2008).

Os dados de altura dos picos (unidades de fluorescência) foram transformados em dados relativos para permitir uma melhor comparação entre as amostras, minimizando os efeitos causados por diferenças entre as quantidades de DNA utilizadas nas reações. Essa 
transformação foi feita dividindo a altura de cada pico pela soma das alturas de todos os picos encontrados em uma amostra. Isso é análogo a definir a porcentagem que cada T-RF representa do perfil total, ou seja, sua abundância relativa (CULMAN et al., 2008).

A matriz de dados gerada após esse procedimento serviu de base para análises estatísticas e para a construção de diagramas de Venn e histogramas, utilizados para representar graficamente a distribuição dos T-RFs entre os perfis das comunidades bacterianas dos solos utilizados e a abundância relativa com que os mesmos apareceram em cada um desses perfis.

\subsection{PCR quantitativo em tempo real (qPCR)}

\subsubsection{Ensaios para quantificação dos genes 16S rRNA, nirK, cnorB e nosZ}

Os genes 16S rRNA, nirK, cnorB e nosZ foram quantificados em todas as amostras de DNA por meio da técnica de qPCR. Os primers e as condições de amplificação utilizados no processo estão especificados na Tabela 2. Todas as reações foram preparadas em soluções contendo $5 \mu \mathrm{L}$ de Maxima SYBR Green/ROX qPCR Master Mix (2×) (Fermentas); 0,5 $\mu \mathrm{M}$ de cada primer; $1 \mu \mathrm{L}$ de DNA e água ultrapura esterilizada para um volume final de $10 \mu \mathrm{L}$. Para realizá-las, utilizou-se o StepOne Plus ${ }^{\mathrm{TM}}$ Real-Time PCR System (Applied Biosystems). 
Tabela 2 - Primers utilizados para a amplificação dos genes 16S rRNA, nirk, cnorB e nosZ e as respectivas condições utilizadas nas reações de PCR quantitativo

\begin{tabular}{|c|c|c|c|c|c|}
\hline $\begin{array}{l}\text { Gene } \\
\text { alvo }\end{array}$ & Primer & $\begin{array}{c}\text { Sequência } \\
\left(5^{\prime}-3^{\prime}\right)\end{array}$ & $\begin{array}{l}\text { Fragmento } \\
(\mathbf{p b})\end{array}$ & Referência & $\begin{array}{l}\text { Condições de } \\
\text { amplificação }\end{array}$ \\
\hline $\begin{array}{l}16 \mathrm{~S} \\
\text { rRNA }\end{array}$ & $\begin{array}{l}\text { U968f } \\
1387 \mathrm{r}\end{array}$ & $\begin{array}{l}\text { AACGCGAAGAACCTTAC } \\
\text { GGGCGGWGTGTACAAGGC }\end{array}$ & 437 & $\begin{array}{l}\text { Heuer et al. (1997) } \\
\text { Marchesi et al. (1998) }\end{array}$ & $\begin{array}{l}94^{\circ} \mathrm{C}-10 \mathrm{~min} ; 40 \text { ciclos de: } 94^{\circ} \mathrm{C}- \\
15 \mathrm{~s}, 56^{\circ} \mathrm{C}-30 \text { s e } 72^{\circ} \mathrm{C}-45 \mathrm{~s} .\end{array}$ \\
\hline nirK & $\begin{array}{l}\operatorname{nirK1F} \\
\operatorname{nirK5R}\end{array}$ & $\begin{array}{l}\text { GGMATGGTKCCSTGGCA } \\
\text { GCCTCGATCAGRTTRTGG }\end{array}$ & 515 & Braker et al. (1998) & $\begin{array}{l}95^{\circ} \mathrm{C}-10 \mathrm{~min} ; 37 \text { ciclos de: } 95^{\circ} \mathrm{C}- \\
15 \mathrm{~s}, 57^{\circ} \mathrm{C}-30 \text { s e } 72^{\circ} \mathrm{C}-30 \mathrm{~s} .\end{array}$ \\
\hline cnorB & $\begin{array}{l}\operatorname{cnorB}_{b} F \\
\text { cnorB }_{b} R\end{array}$ & $\begin{array}{l}\text { AIGTGGTCGAGAAGTGGCTCTA } \\
\text { TCTGIACGGTGAAGATCACC }\end{array}$ & 177 & Dandie et al. (2007) & $\begin{array}{l}95^{\circ} \mathrm{C}-10 \mathrm{~min} ; 40 \text { ciclos de: } 95^{\circ} \mathrm{C}- \\
15 \mathrm{~s}, 60^{\circ} \mathrm{C}-30 \text { s e } 80^{\circ} \mathrm{C}-30 \mathrm{~s} .\end{array}$ \\
\hline $\operatorname{nos} Z$ & $\begin{array}{l}\operatorname{nos} Z 2 F \\
\text { nosZ2R }\end{array}$ & $\begin{array}{l}\text { CGCRACGGCAASAAGGISMSSGT } \\
\text { CAKRTGCAKSGCRTGGCAGAA }\end{array}$ & 267 & Henry et al. (2006) & $\begin{array}{l}95^{\circ} \mathrm{C}-10 \mathrm{~min} ; 6 \text { ciclos de: } 95^{\circ} \mathrm{C}- \\
15 \mathrm{~s}, 65^{\circ} \mathrm{C}-20 \mathrm{~s} \text { (touchdown com } \\
\text { redução de } 1{ }^{\circ} \mathrm{C} \text { a cada ciclo) e } 72 \\
{ }^{\circ} \mathrm{C}-30 \mathrm{~s} ; 40 \text { ciclos de: } 95^{\circ} \mathrm{C}-20 \mathrm{~s} \text {, } \\
60^{\circ} \mathrm{C}-15 \mathrm{~s} \text { e } 72^{\circ} \mathrm{C}-30 \mathrm{~s} .\end{array}$ \\
\hline
\end{tabular}


Os produtos amplificados foram expostos a um gradiente crescente de temperatura e a coleta de dados de fluorescência foi realizada em intervalores regulares a fim de monitorar a dinâmica de dissociação dos mesmos. Esse processo, que permitiu construir as curvas de melting para checagem da especificidade das reações, consistiu em manter os amplicons por 1 min na temperatura utilizada na etapa de anelamento (que variou de uma reação para outra) para depois aumentá-la gradativamente até $95^{\circ} \mathrm{C}$. A leitura dos dados foi realizada a cada incremento de $0,7^{\circ} \mathrm{C}$.

Plasmídeos contendo cada um dos genes de interesse (padrões externos) encontravam-se disponíveis no laboratório de Biologia Celular e Molecular (CENA/USP) e foram utilizados como molde em reações de PCR convencionais feitas com os primers e condições especificados na Tabela 2. O produto final de tais reações foi purificado e quantificado em espectrofotômetro, de modo que o número de cópias de amplicons em cada um deles foi determinado. Através de diluições seriadas (1:10), foi possível obter amostras contendo números conhecidos de cópias dos produtos do $16 \mathrm{~S}$ rRNA, nirK, cnoB e nosZ para a construção das curvas-padrão. Cada curva foi construída com base em cinco diluições.

Todas as reações, tanto as feitas com o DNA extraído das amostras de solo como aquelas em que se empregaram as diluições referentes às curvas-padrão, foram realizadas em triplicata (réplicas técnicas). O mesmo foi feito para os controles negativos, nos quais se utilizou água como molde em vez de DNA.

\subsubsection{Processamento dos dados de qPCR}

O resultado das qPCRs foram analisados com o StepOne Software v2.3 (Applied Biosystems). Somente os dados obtidos através de reações em que a especificidade foi confirmada pela análise das curvas de melting e que apresentaram valores apropriados de eficiência (entre 80 e 110\%) foram considerados nas análises. As reações que não se mostraram adequadas com relação a esses parâmetros foram refeitas, bem como aquelas que se revelaram contaminadas após a análise dos controles negativos.

Os dados que passaram por essa triagem inicial foram exportados para planilhas eletrônicas no programa Microsoft Excel (Microsoft) e os valores de abundância de cada um dos genes foram convertidos para o número de cópias presente em cada grama de solo seco 
(cópias/g de solo seco). Após essa transformação, os dados foram organizados para as análises estatísticas e as abundâncias médias dos genes $16 \mathrm{~S}$ rRNA, nirK, cnoB e nosZ nos solos sob diferentes tratamentos ao longo do experimento foram calculadas e graficamente representadas.

\subsection{Análises estatísticas}

Os dados utilizados foram verificados quanto a sua normalidade e, quando necessário, transformados para se adequarem aos pressupostos da análise de variância (ANOVA) (normalidade e homocedasticidade). Aqueles obtidos por cromatografia gasosa foram transformados de acordo com o método de Box-Cox (BOX; COX, 1964), enquanto os dados da técnica de qPCR foram convertidos para a escala logarítmica (logaritmos neperianos). Estes dados transformados foram utilizados nas análises estatísticas descritas a seguir, mas as médias apresentadas ao longo do trabalho foram calculadas a partir dos seus valores originais. Para realizar estes testes foi utilizado o programa SAS v9.2 (SAS Institute, Cary, NC).

A fim de detectar as diferenças existentes entre os três solos utilizados no experimento, os dados referentes aos atributos físicos e químicos dos mesmos foram submetidos a uma ANOVA e as médias foram comparadas pelo teste de Tukey $(P<0,05)$. O mesmo foi feito para os dados de abundância dos genes $16 \mathrm{~S}$ rRNA, nirK, cnorB e nosZ obtidos no início do experimento, antes da aplicação dos tratamentos, com objetivo de demonstrar as peculiaridades exibidas pelos solos das diferentes áreas de coleta com relação a quantidade total de genes bacterianos e de genes associados ao processo de desnitrificação. Estas análises foram realizadas através do programa SISVAR v5.3 (FERREIRA, 2010).

Com o objetivo de verificar de maneira mais detalhada os efeitos significativos do teor de umidade, análises foram realizadas separadamente para cada solo utilizado no experimento. Estas foram feitas para cada dia de amostragem e para cada parâmetro analisado (fluxo de $\mathrm{N}_{2} \mathrm{O}$ e número de cópias de cada gene). Desse modo, cada ANOVA foi utilizada para comparar, num dado momento, as amostras de solo provenientes de uma mesma área com diferentes teores de umidade (original, 60 e 90\% da CC) quanto a taxa de produção de gás e abundância dos genes $16 \mathrm{~S}$ rRNA, nirK, cnorB e nosZ. Os parâmetros que foram afetados pelo conteúdo de água também tiveram as médias que exibiram ao longo do tempo comparadas. 
Os perfis de T-RFLP das comunidades bacterianas presentes nos solos das diferentes áreas de coleta foram comparados através de Análises de Componentes Principais (PCAs). Para isso, os dados que passaram pelo processamento descrito anteriormente foram utilizados para construir matrizes de variância-covariância, a partir das quais esse tipo de análise multivariada pôde ser realizado. PCAs também foram feitas para avaliar a variação das comunidades bacterianas em função dos tratamentos ao longo do período de incubação dos microcosmos. Todas essas análises foram realizadas com o programa PAST v3.0 (HAMMER; HARPER; RYAN, 2001).

Por fim, o coeficiente de correlação de Pearson foi utilizado para avaliar as relações existentes entre as variáveis analisadas no presente estudo. Para isso, também foi utilizado o programa PAST v3.0 (HAMMER; HARPER; RYAN, 2001). 


\section{RESULTADOS E DISCUSSÃO}

\subsection{Caracterização físico-química das amostras de solo utilizadas no experimento}

Os resultados das análises estatísticas revelaram uma série de diferenças entre os solos das três áreas de coleta com relação às suas propriedades físicas e químicas, as quais são representadas na Tabela 3.

Tabela 3 - Atributos químicos e físicos dos solos coletados em áreas de cultivo de cana-deaçúcar, pastagem e vegetação nativa para utilização em experimento de microcosmos

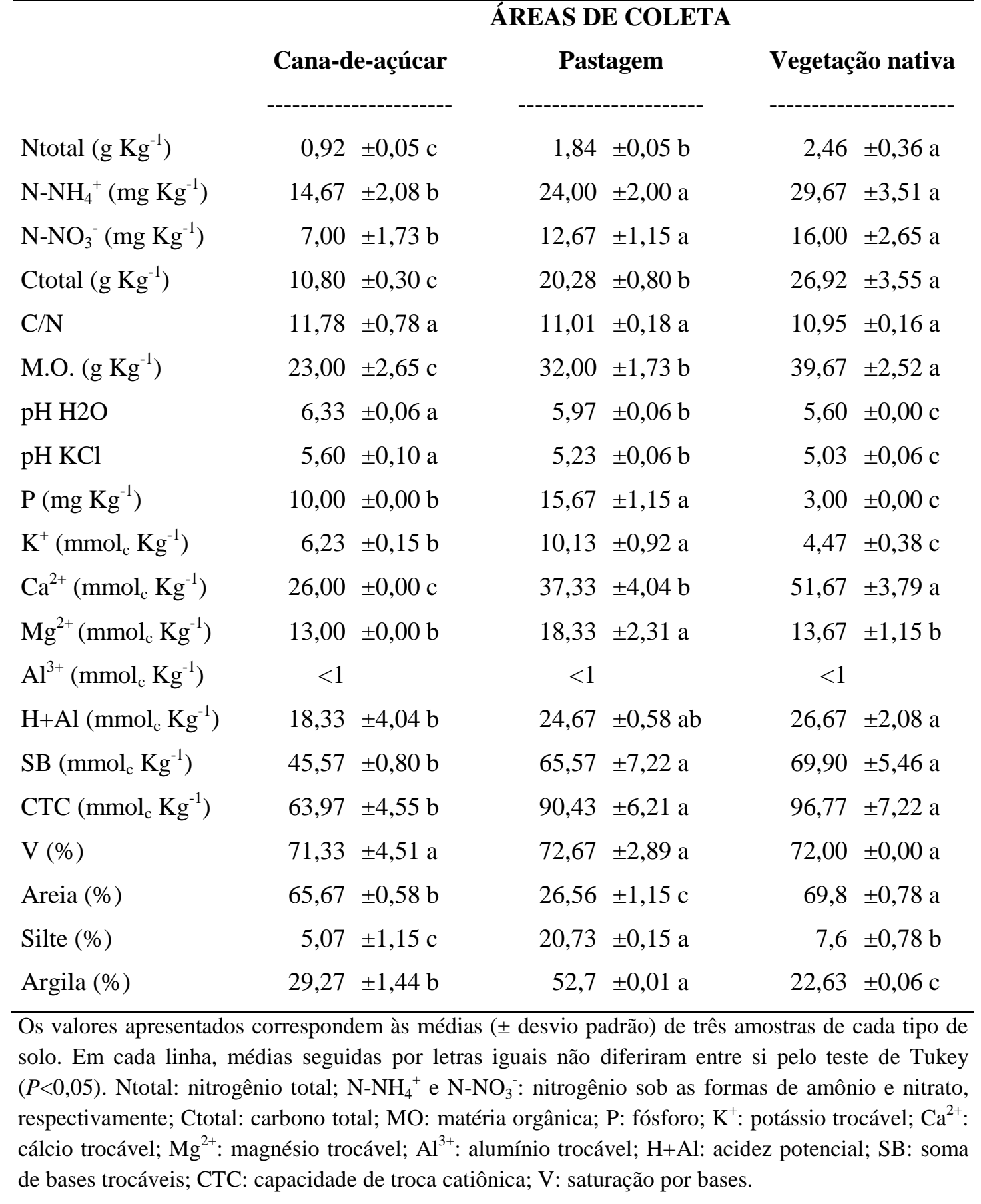


As amostras provenientes da área de vegetação nativa foram as que apresentaram os maiores teores de $\mathrm{MO}, \mathrm{N}$ e $\mathrm{C}$. Estes atributos apareceram com valores intermediários nos solos da pastagem e se mostraram mais reduzidos na área do canavial, na qual também foram encontradas as menores quantidades de $\mathrm{NO}_{3}{ }^{-}$e $\mathrm{NH}_{4}{ }^{+}$. Diferenças quanto a estes parâmetros, de maneira geral, podem ser um resultado do processo de mudança de uso do solo.

Muitos estudos demonstram que a substituição de florestas naturais por sistemas agrícolas pode levar a reduções significativas da quantidade de MO do solo e que a intensidade das práticas de cultivo adotadas é um fator importante, capaz de determinar a magnitude dessas perdas (SZAJDAK; JEZIERSKI; CABRERA, 2003). Uma vez que a MO é o maior reservatório de C da superfície terrestre (SMITH, 2004) e que mais de $90 \%$ do N presente no solo está contido na mesma, ela também afeta os estoques desses dois elementos (MEYSNER; SZAJDAK; KUS, 2006; SCHOLES; BREEMEN, 1997).

Outros elementos também apareceram com abundâncias distintas nos locais de coleta. Embora o cálcio $\left(\mathrm{Ca}^{2+}\right)$ tenha se mostrado mais abundante na área de vegetação nativa, esta apresentou menores teores de fósforo $(\mathrm{P})$, potássio $\left(\mathrm{K}^{+}\right)$e magnésio $\left(\mathrm{Mg}^{2+}\right)$ do que as outras, nas quais esses nutrientes geralmente são introduzidos por meio da adição de fertilizantes ou da calagem (RAIJ et al., 1997).

Todos os solos apresentaram $\mathrm{pH}$ abaixo de 7, mas os níveis de acidez variaram significativamente de uma área para a outra. Enquanto o solo cultivado com cana-de-açúcar se mostrou mais próximo da neutralidade, provavelmente porque foi corrigido para fornecer uma condição favorável ao desenvolvimento dessa espécie vegetal, valores mais baixos de $\mathrm{pH}$ foram observados nas amostras provenientes das duas outras áreas. Dentre estas, foi a floresta que apresentou os solo mais ácido.

$\mathrm{Na}$ área do canavial, o solo mostrou uma menor capacidade de troca catiônica (CTC) e soma de bases $(\mathrm{SB})$ que os demais. A CTC se refere à quantidade total de cátions permutáveis $\left(\mathrm{Ca}^{2+}+\mathrm{Mg}^{2+}+\mathrm{K}^{+}+\mathrm{H}^{+}+\mathrm{Al}^{3+}\right)$ que o mesmo é capaz de adsorver à superfície de seus constituintes minerais e orgânicos (isto é, de manter ligados às cargas negativas de suas argilas, MO etc.). Por outro lado, a SB é a soma dos teores desses cátions excluindo-se o $\mathrm{H}^{+} \mathrm{e}$ $\mathrm{Al}^{3+}$, os quais não são considerados básicos. A partir desses dois atributos, é possível calcular a saturação por bases (V) do solo (RONQUIM, 2010).

A V é um bom indicativo das condições gerais de fertilidade do solo e, apesar das diferenças quanto a CTC e SB, os valores calculados para a mesma foram iguais para os solos das três áreas. Isso quer dizer que todos eles apresentaram porcentagens iguais (cerca de 70\%) de cargas negativas sendo ocupadas por $\mathrm{Ca}^{2+}, \mathrm{Mg}^{2+} \mathrm{e} \mathrm{K}^{+}$, ao invés dos cátions potencialmente 
tóxicos, como $\mathrm{H}^{+}$e $\mathrm{Al}^{3+}$. Dessa forma, todos eles puderam ser considerados férteis $(\mathrm{V}>50 \%)$ (RONQUIM, 2010).

Além de todas as diferenças com relação aos atributos químicos, os solos também variaram quanto às suas propriedades físicas. Areia, silte e argila apareceram em proporções diferentes em cada um deles e, considerando a classificação da Embrapa (2006), os solos da floresta e do canavial apresentaram textura média (menos de $35 \%$ de argila e mais de $15 \%$ de areia) enquanto o da pastagem pôde ser caracterizado como argiloso (35\% a $60 \%$ de argila).

\subsection{Umidade e capacidade de campo dos solos}

O solo da área de pastagem foi o que apresentou maior teor de umidade (18\%), seguido do solo da área de floresta (13\%) e do canavial (10\%). Os teores de umidade na CC foram de $51 \%$ para o solo da pastagem, $46 \%$ para o da área de vegetação nativa e $32 \%$ para o solo proveniente da área cultivada com cana-de-açúcar.

\subsection{Experimento de microcosmos}

\subsubsection{Emissões de $\mathrm{N}_{2} \mathrm{O}$}

Os fluxos de $\mathrm{N}-\mathrm{N}_{2} \mathrm{O}$ a partir dos solos submetidos aos diferentes tratamentos, mensurados durante o período de incubação dos microcosmos, estão representados na Figura 10. Para os três solos, incrementos significativos na produção deste gás ocorreram somente por parte das amostras que receberam volumes de água suficiente para atingir $90 \%$ da CC. 

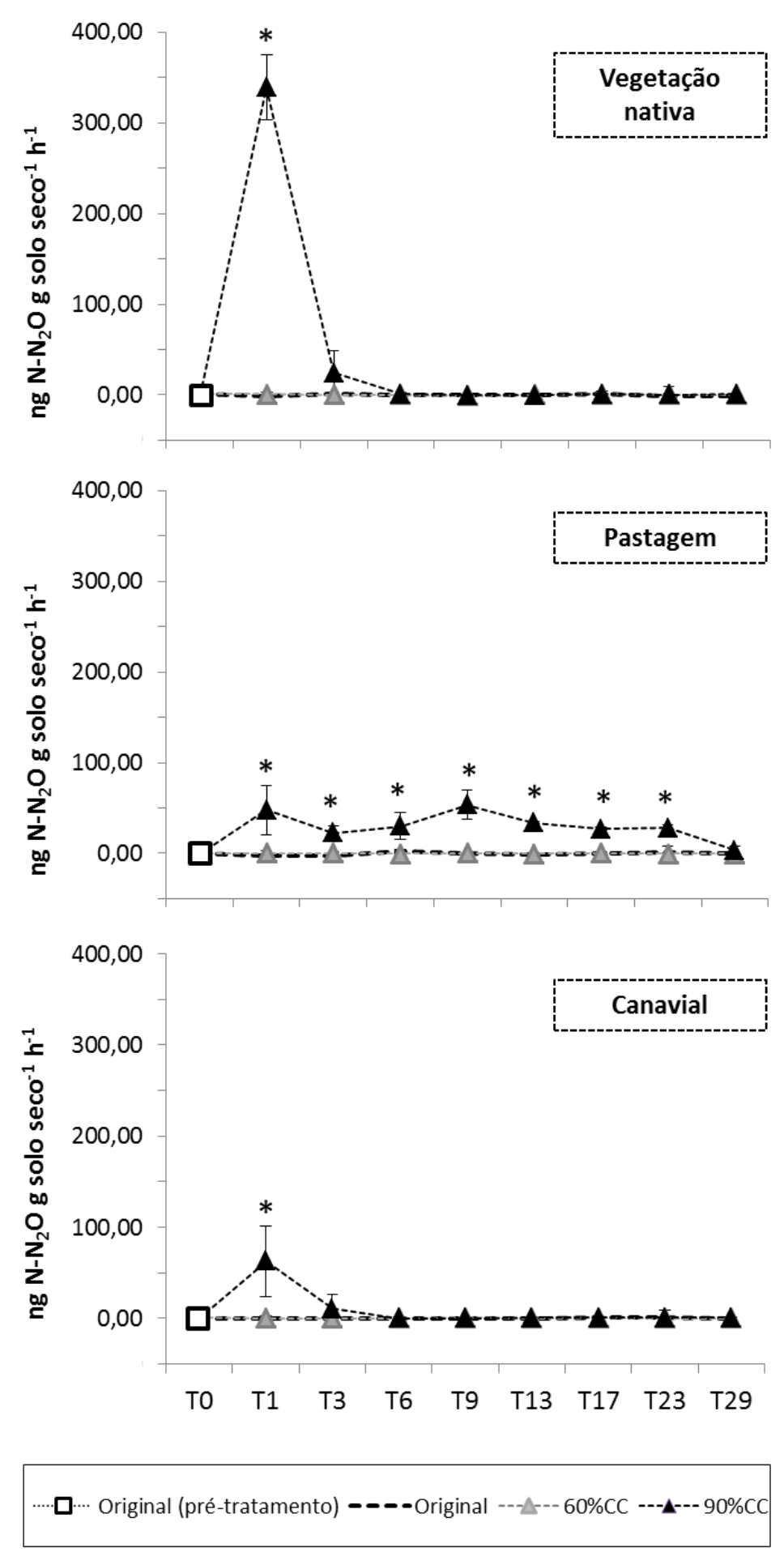

Figura 10 - Produção de $\mathrm{N}_{2} \mathrm{O}$ por amostras de solo de áreas de vegetação nativa, pastagem e cultivo de cana-de-açúcar, mantidas com diferentes teores de umidade, conforme indicado na legenda. Original (pré-tratamento): amostras antes da aplicação dos tratamentos; Original: teor inalterado; $60 \% \mathrm{CC}$ e $90 \% \mathrm{CC}$ : solos com umidade correspondente a $60 \%$ e a $90 \%$ da capacidade de campo, respectivamente. Os símbolos representam os valores médios e as barras se referem ao desvio-padrão (T0: $\mathrm{n}=12$; T1 a T29: $\mathrm{n}=4)$. * indica que as médias diferiram das que não estão acompanhadas pelo símbolo pelo teste de Tukey ao nível de $5 \%$ de significância. 
As emissões pelas amostras em que a umidade original foi preservada e por aquelas incubadas com $60 \%$ da CC foram iguais entre si $(P>0,05)$ ao longo de todo o experimento, exibindo níveis extremamente reduzidos e constantes. Nesses dois casos, é provável que a quantidade de água disponível não tenha sido suficiente para criar condições favoráveis à atividade das bactérias envolvidas na produção de $\mathrm{N}_{2} \mathrm{O}$ ou para permitir uma difusão efetiva de substratos importantes até as mesmas (STARK; FIRESTONE, 1995). Resultados semelhantes já foram encontrados em outros estudos, nos quais se verificaram baixas taxas de emissão desse gás por solos mais secos e aumentos expressivos quando grande parte do espaço poroso (65-80\%) está preenchida por água (DOBBIE; MCTAGGART; SMITH, 1999; GRANLI; BØCKMAN, 1994; VELTHOF; OENEMA, 1995).

Embora seja difícil atribuir a emissão de $\mathrm{N}_{2} \mathrm{O}$ a um único processo - porque além da desnitrificação, existem outros mecanismos biogeoquímicos que podem levar à sua produção, como a nitrificação (BLACKMER; BREMNER, 1978), a desnitrificação nitrificante (POTH; FOCHT, 1985; WRAGE et al., 2001) e a quimiodesnitrificação (CLARK, 1962) - o aumento da produção deste GEE sob condições de alta umidade, quando aumenta a proporção do volume de solo anaeróbio (RENAULT; SIERRA 1994; SMITH, 1980), costuma ser atribuído à intensificação da atividade desnitrificante, que é favorecida sob essas condições (MCTAGGART et al., 2002).

A resposta ao ajuste da umidade para $90 \%$ da CC se deu de maneira simultânea nos solos de floresta, pastagem e cultivo de cana-de-açúcar. O fato de a mesma ter sido detectada logo no dia seguinte à realização deste procedimento permite concluir que a umidade exerceu um efeito praticamente imediato sobre bactérias produtoras deste GEE presentes nas amostras estudadas. De fato, já foi demonstrado por Davidson (1992) que tais organismos podem ter sua atividade estimulada poucos minutos após o umedecimento do solo.

As taxas de emissão de $\mathrm{N}_{2} \mathrm{O}$ alcançadas pelas amostras provenientes da área de vegetação nativa foram significativamente maiores do que aquelas exibidas pelos solos das outras áreas. No T1, por exemplo, enquanto o tratamento $\mathrm{F}_{90 \% \mathrm{CC}}$ gerou em média 339,18 $( \pm 35,8)$ ng de $\mathrm{N}-\mathrm{N}_{2} \mathrm{O} \mathrm{g}^{-1}$ de solo seco ${ }^{-1}$, os fluxos registrados para $\mathrm{P}_{90 \% \mathrm{CC}}$ e $\mathrm{C}_{90 \% \mathrm{CC}}$ foram de $47,84( \pm 26,9)$ e $62,78( \pm 38,9) \mathrm{ng}$ de $\mathrm{N}-\mathrm{N}_{2} \mathrm{O} \mathrm{g}^{-1}$ de solo seco $\mathrm{h}^{-1}$, respectivamente. Assim, verificou-se que além do efeito associado ao conteúdo de água, as emissões deste GEE também variaram em função do solo utilizado.

Os solos $\mathrm{F}_{90 \% \mathrm{CC}}$ e $\mathrm{C}_{90 \% \mathrm{CC}}$ exibiram padrões semelhantes no que se refere à dinâmica do fluxo do gás ao longo o período de incubação. Nos dois casos, as taxas máximas de produção foram observadas no T1 e diminuíram logo em seguida, de modo que a partir do T6 não 
puderam mais ser diferenciadas daquelas apresentadas pelos outros tratamentos. Por outro lado, o solo do $\mathrm{P}_{90 \% \text { CC }}$ sustentou a taxa de emissão de $\mathrm{N}_{2} \mathrm{O}$ observada no T1 por um período mais longo, sendo que a produção do gás só diminuiu a ponto de poder ser considerada igual a do $\mathrm{P}_{\text {original }}$ e do $\mathrm{P}_{60 \% \mathrm{CC}}$ no T29.

Embora o solo $\mathrm{P}_{90 \% \mathrm{CC}}$ não tenha exibido uma produção de GEE tão intensa em nenhum dos dias em que as análises foram feitas, o fato de o mesmo ter emitido o gás continuamente resultou numa produção cumulativa maior que a estimada para os outros solos $(20,6 \pm 1,7 \mu \mathrm{g}$ de $\mathrm{N}-\mathrm{N}_{2} \mathrm{O} \mathrm{g}^{-1}$ solo seco) (Figura 11). Como nos solos de floresta e de cultivo de cana foi observado somente um pico de emissão, os valores estimados da quantidade total de gás produzida ao longo do período de incubação foram proporcionais aos mesmos, sendo maiores para o $\mathrm{F}_{90 \% \mathrm{CC}}\left(13,9 \pm 1,2 \mu \mathrm{g}\right.$ de $\mathrm{N}-\mathrm{N}_{2} \mathrm{O} \mathrm{g}^{-1}$ solo seco) do que para o $\mathrm{C}_{90 \% \mathrm{CC}}(3,3 \pm 1,8 \mu \mathrm{g}$ de $\mathrm{N}-\mathrm{N}_{2} \mathrm{O} \mathrm{g}^{-1}$ solo seco). As emissões cumulativas referentes aos solos mantidos com umidade original ou ajustada para $60 \%$ da CC não foram significativas.

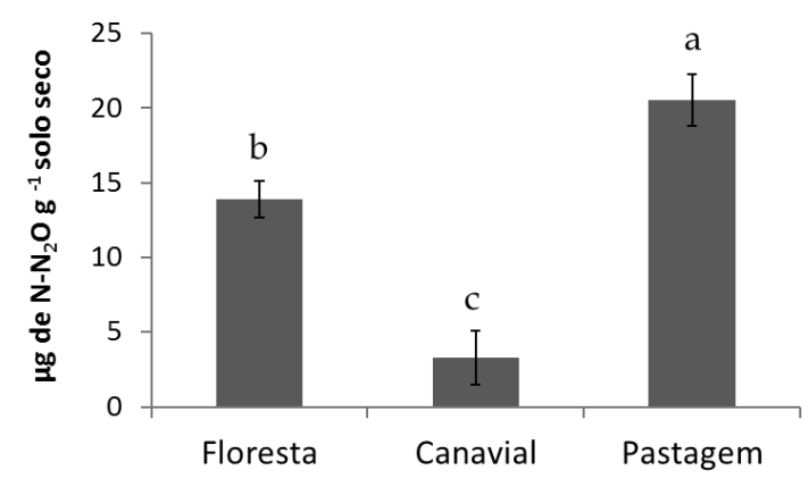

Figura 11 - Emissão cumulativa de $\mathrm{N}_{2} \mathrm{O}$ pelos solos provenientes de área de vegetação nativa, canavial e pastagem com umidade ajustada para $90 \%$ da capacidade de campo, considerando o período de incubação de 30 dias. Os valores representam as médias de quatro repetições e as barras se referem ao desvio-padrão $(n=4)$. Letras diferentes indicam que as médias diferiram entre si pelo teste de Tukey ao nível de 5\% de significância.

Provavelmente, parte das discrepâncias verificadas entre os solos utilizados no experimento com relação à magnitude das taxas de emissão de $\mathrm{N}_{2} \mathrm{O}$ se deve ao fato de os mesmos terem diferido quanto a atributos reconhecidamente capazes de influenciar a produção desse gás, como os teores de $\mathrm{N}$ mineral $\left(\mathrm{NO}_{3}{ }^{-}\right.$e $\left.\mathrm{NH}_{4}{ }^{+}\right)$, de $\mathrm{C}$ e de $\mathrm{MO}$ e o $\mathrm{pH}$, que afetam a atividade dos organismos desnitrificantes (DOBBIE; MCTAGGART; SMITH, 1999; GRANLI; BØCKMAN, 1994; WLODARCZYK; STEPNIEWSKA; BRZEZINSKA, 2003). 
A textura do solo pode ter sido o fator responsável pelas diferenças referentes à flutuação das taxas de emissão do GEE. Geralmente, os solos compostos por partículas de maiores dimensões exibem picos de emissão mais curtos do que aqueles de textura mais fina (SEXSTON; PARKIN; TIEDJE, 1985). Assim, o solo da pastagem, com maior teor de argila, apresentou fluxos positivos de $\mathrm{N}_{2} \mathrm{O}$ por um maior período de tempo do que os solos da floresta e do canavial, os quais possuíam maiores proporções de areia em sua composição.

\subsubsection{Extração do DNA total do solo}

Para compreender as relações existentes entre as emissões do gás, a estrutura da comunidade bacteriana e a abundância dos genes funcionais, bem como as variações desses parâmetros que se deram em função da umidade, optou-se por extrair o DNA das amostras coletadas em quatro dias distintos: (1) no T0, quando os tratamentos ainda não haviam sido aplicados; (2) no T1, quando as taxas de emissão de $\mathrm{N}_{2} \mathrm{O}$ dos solos com a umidade ajustada para 90\% da CC se diferenciaram das demais; (3) no T6, quando essas taxas retornaram à sua condição inicial (pelo menos para os solos da floresta e do canavial) e (4) no T29, ao final do experimento.

Pela análise dos produtos extraídos em gel de agarose $1 \%$ e pela quantificação dos mesmos por espectrofotometria, constatou-se que o DNA obtido apresentava qualidade e quantidade adequadas para a realização das análises moleculares (T-RFLP e qPCR). As amostras apresentaram concentrações entre $22 \mathrm{ng} \mu \mathrm{L}^{-1}$ e $95 \mathrm{ng} \mu \mathrm{L}^{-1}$.

\subsubsection{Análise de T-RFLP do gene 16S rRNA de Bacteria}

\subsubsection{Caracterização das comunidades bacterianas dos solos utilizados no experimento}

Os perfis de T-RFLP das comunidades de Bacteria dos solos das três áreas de estudo apresentaram diferenças quanto ao número de T-RFs gerados. Quando a enzima utilizada na etapa de restrição foi a MspI, 160 T-RFs distintos foram produzidos, sendo que 118 e 117 deles foram detectados nas amostras de vegetação nativa e de pastagem, respectivamente. Já nas amostras da área cultivada com cana-de-açúcar, o número de T-RFs encontrados foi mais baixo (somente 72). Para a HhaI, a quantidade total de T-RFs foi de 148. Estes também se mostraram menos abundantes no canavial, onde foram observados apenas $89 \mathrm{~T}-\mathrm{RF}$, enquanto 110 estavam presentes na floresta e 102 no pasto. 
A menor riqueza de UTO's do solo cultivado com cana-de-açúcar provavelmente decorre da forte influência antrópica sob a qual o mesmo se encontra. Em áreas destinadas à produção agrícola, o uso intensivo do solo pode acarretar sua degradação física e química e, dessa forma, criar condições desfavoráveis para alguns grupos bacterianos. Além disso, as práticas de cultivo (fertilização, preparo, colheita etc.) representam uma fonte periódica de distúrbio e podem contribuir ainda mais para a redução da diversidade taxonômica de suas comunidades, pois nem todas as espécies são capazes de resistir a variações ambientais bruscas (JANGID et al., 2008). Assim, o caráter mais estável dos solos da floresta e da pastagem teria favorecido a formação de comunidades mais complexas.

Pela análise dos diagramas de Venn (Figura 12), que fornecem uma ideia de como as UTO's se distribuíram pelos ambientes estudados, é possível notar que uma parte considerável delas foi detectada em todos os locais de coleta. Cerca de $32 \%$ dos T-RFs obtidos com a restrição pela enzima MspI mostraram estar presentes, concomitantemente, nos solos da floresta, da pastagem e do cultivo de cana-de-açúcar. Em relação aos T-RFs associados à HhaI, aqueles comuns a todos os ambientes avaliados representaram $41 \%$ do total.

Mspl

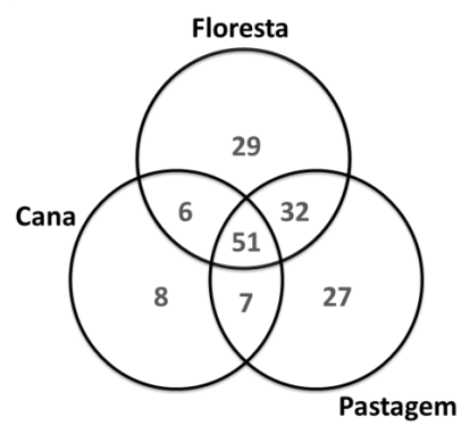

Hhal

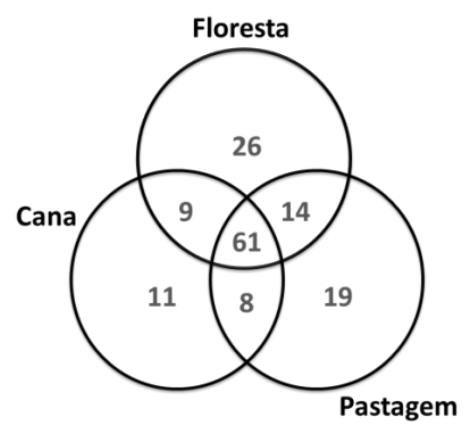

Figura 12 - Diagramas de Venn dos T-RFs do gene 16S rRNA de Bacteria. Os números apresentados correspondem ao número de T-RFs encontrados em cada área após restrição com as enzimas MspI e HhaI, conforme indicado

A ubiquidade é uma característica comumente atribuída a microrganismos generalistas, que são aqueles capazes de se adaptar a diferentes condições ambientais (FIERER, 2008; BARBERÁN et al., 2014). Assim, seria razoável sugerir que as UTO’s detectadas simultaneamente nos solos das três áreas de estudo, os quais são contrastantes quanto aos seus atributos físicos e químicos, representam grupos bacterianos com este tipo de comportamento. 
Outras UTO's apresentaram distribuição um pouco mais restrita, sendo identificadas somente nas comunidades de duas das três áreas avaliadas. De modo geral, os solos de mata nativa e pastagem foram os que apresentaram maior número de T-RFs em comum (52\% dos T-RFs gerados pela MspI e 51\% dos gerados pela Hhal). Estes dois ambientes também compartilharam T-RFs com o solo cultivado com cana, mas em menores quantidades.

Apesar dessas semelhanças com relação à composição taxonômica, a existência de UTO's exclusivas em cada ambiente revelou certo grau de diferenciação das comunidades estudadas. Em geral, os solos coletados na área de floresta foram os que apresentaram maior número de T-RFs específicos, sendo que $25 \%$ de todos os que foram gerados pela MspI para essa área não foram detectados nas outras. Para a pastagem esse valor foi semelhante, representando $23 \%$ dos T-RFs encontrados. Em contrapartida, somente $11 \%$ dos T-RFs presentes no canavial aparecem exclusivamente nesse sistema. Os valores percentuais da análise feita com a HhaI foram praticamente os mesmos.

As peculiaridades das três comunidades bacterianas tornaram-se mais evidentes quando, além das comparações baseadas na simples presença e ausência de T-RFs, levou-se em conta a abundância relativa de cada um deles. Isso pode ser observado nos histogramas apresentados a seguir (Figura 13), nos quais estão ilustradas as porcentagens que as UTO's dominantes (com abundância relativa maior que 1\%) representam na comunidade de cada área. 

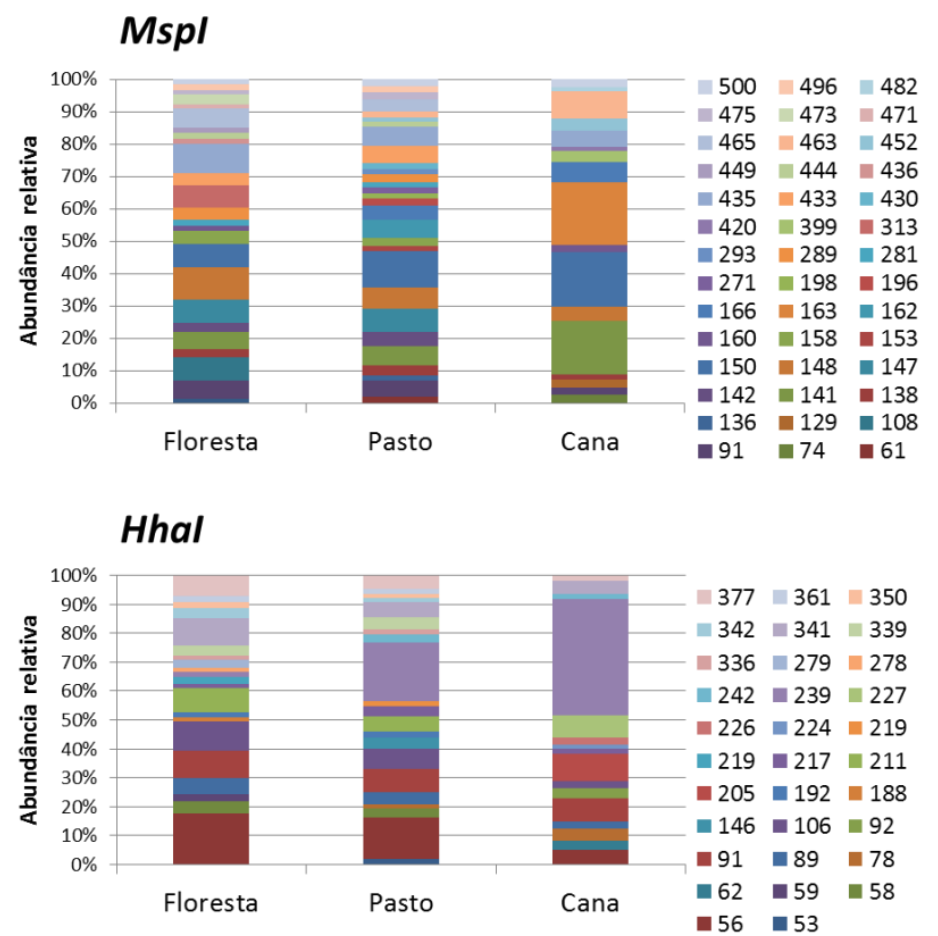

Figura 13 - Abundância relativa de T-RFs do gene 16S rRNA de Bacteria. Os diagramas mostram os resultados obtidos após restrição com as enzimas HhaI e MspI, conforme indicado. Os números na legenda indicam o tamanho dos fragmentos, em pares de bases. Somente fragmentos com abundância relativa superior a $1 \%$ estão representados

Dentre as UTO's dominantes comuns a todos os locais de coleta, constatou-se que as mesmas apareceram com abundâncias relativas distintas em cada um deles. Para a enzima MspI, por exemplo, os T-RF's de 91, 148, 158 e 435 pares de bases foram mais abundantes na floresta, um pouco menos na pastagem e estavam presentes em proporções ainda menores no canavial. Por outro lado, alguns T-RF's foram encontrados em quantidades ínfimas no solo da floresta, intermediárias no da pastagem e com grande abundância naquele cultivado com cana-de-açúcar, como os de 141 e 150 pares de bases.

O fato de determinadas UTO's terem se mostrado muito mais abundantes do que as demais na comunidade presente no solo do canavial contribuiu fortemente para torná-la mais divergente do ponto de vista estrutural. Nas comunidades da floresta e pastagem, as UTO's dominantes demonstraram coexistir em proporções menos discrepantes, ou seja, apresentaram uma distribuição mais equitativa. Esse padrão foi verificado tanto nos perfis obtidos com a enzima MspI quanto nos da HhaI. 
Em geral, dois processos distintos podem levar ao desenvolvimento exacerbado de um pequeno número de espécies microbianas. Pode ocorrer, por exemplo, que dentre as bactérias presentes na comunidade existam aquelas mais adaptadas às condições encontradas no solo, as quais seriam capazes de se desenvolver melhor e de se expandir ao longo da área, suprimindo a proliferação das demais e mantendo-as em proporções menores. Porém, esse fenômeno também costuma ser observado em ambientes homogêneos - isto é, que apresentam condições uniformes por áreas extensas -, os quais podem favorecer a multiplicação de um grupo restrito de espécies fenotipicamente semelhantes, que seriam aquelas capazes de se desenvolver bem nas condições predominantes (FUHRMAN; CAMPBELL, 1998).

A ausência de grupos bacterianos altamente dominantes nos solos da floresta e da pastagem, somada ao fato de as mesmas apresentarem maior número de UTO’s em comum, como discutido anteriormente, sugerem que as comunidades dessas duas áreas apresentam um maior nível de similaridade entre si do que com aquela presente no solo do canavial. Isso pôde ser demonstrado de maneira mais objetiva pelas PCA's dos perfis de T-RFLP das comunidades dessas três áreas de coleta.

Nos gráficos de ordenação gerados, os pontos que representam as amostras da área de vegetação nativa e da pastagem se dispuseram de maneira mais próxima na área de plotagem, enquanto aqueles referentes às amostras de solo cultivado com cana-de-açúcar formaram um grupo mais isolado (Figura 14).
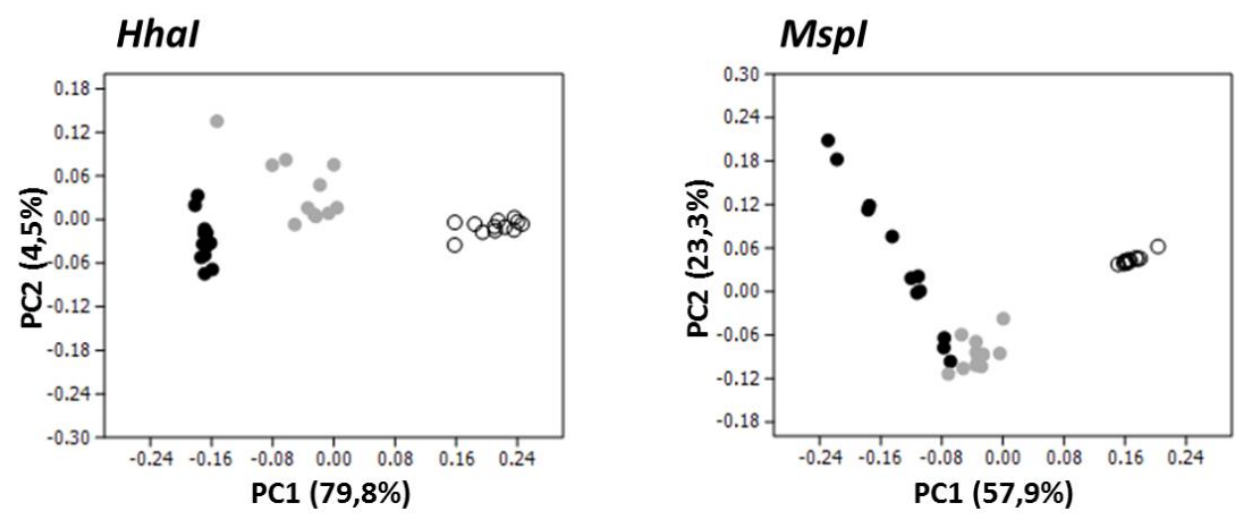

- Floresta - Pastagem ${ }^{\circ}$ Cana-de-açúcar

Figura 14 - Análises de Componentes Principais (PCA) dos perfis de T-RFLP de Bacteria das diferentes áreas de estudo. As enzimas utilizadas na etapa de restrição para gerar os dados apresentados foram a HhaI e MspI, conforme indicado. As porcentagens de variação associadas a cada componente principal (PC1 e PC2) estão indicadas nos eixos 
$\mathrm{O}$ fato de os perfis de T-RFLP de amostras provenientes de uma mesma área de coleta terem formado grupos relativamente distintos, demonstra que as comunidades bacterianas presentes nos solos da floresta, da pastagem e do canavial apresentam estruturas características. Desse modo, os resultados das PCA's estão em conformidade com a análise inicial dos dados, através das quais se verificou que cada uma delas apresentou uma riqueza e uma combinação característica de UTO's.

Diante do exposto, é possível afirmar que a análise de T-RFLP foi eficaz em demonstrar as diferenças que os solos sob diferentes usos apresentaram com relação às suas comunidades bacterianas e que as PCA's permitiram expressar de modo mais claro os níveis dessa diferenciação.

\subsubsection{Análise das variações das comunidades bacterianas ao longo do período de incubação}

As variações que ocorreram ao longo do tempo na estrutura das comunidades bacterianas dos solos de floresta, monocultura de cana-de-açúcar e pastagem após a aplicação dos tratamentos podem ser investigadas pela apreciação das PCA's apresentadas a seguir (Figuras 15, 16 e 17).

Com relação ao solo coletado na área de vegetação nativa, a análise dos perfis de T-RFLP no T1 revelou que as comunidades presentes nas amostras que receberam diferentes volumes de água não apresentaram diferenças estruturais expressivas, visto que os pontos correspondentes aos tratamentos $\mathrm{F}_{\text {original }}, \mathrm{F}_{60 \% \mathrm{CC}}$ e $\mathrm{F}_{90 \% \mathrm{CC}}$ foram plotados de maneira sobreposta no gráfico (Figura 15). No T6, por outro lado, foi possível notar que as comunidades dos solos mantidos com maior teor de umidade se diferenciaram das demais e passaram a formar um agrupamento relativamente distinto. Aparentemente, essas modificações se mantiveram até o final do experimento, pois que também puderam ser observadas no T29. 


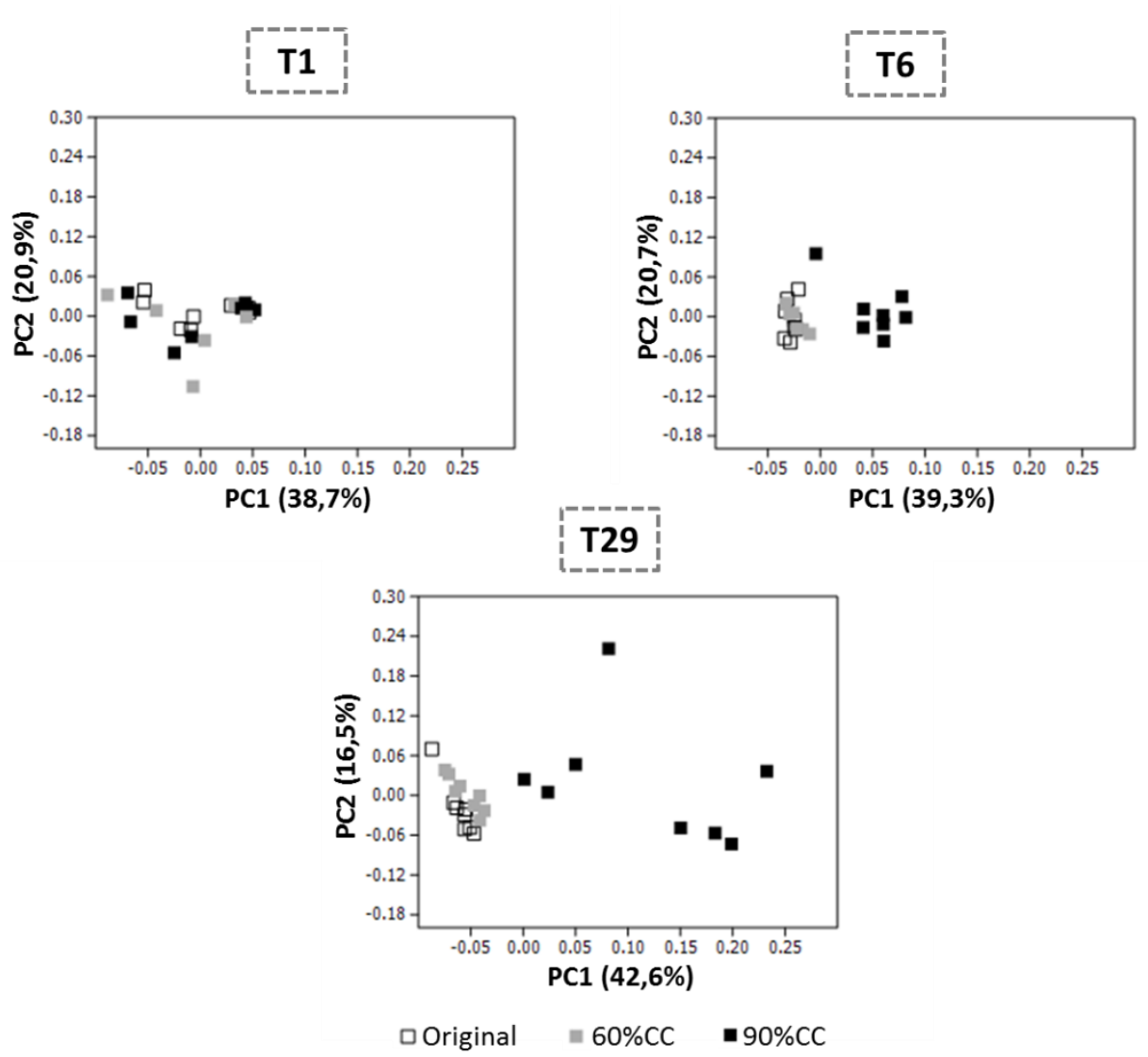

Figura 15 - Análises de Componentes Principais (PCA) das comunidades bacterianas de solos de floresta mantidos com diferentes teores de umidade, conforme indicado na legenda. Original: teor inalterado; 60\% CC e 90\%CC: solos com umidade correspondente a $60 \% \mathrm{e}$ a $90 \%$ da capacidade de campo, respectivamente. As PCAs apresentadas baseiam-se nos dos perfis de T-RFLP do gene 16S rRNA obtidos um (T1), seis (T6) e 29 (T29) dias após a aplicação dos tratamentos. A enzima utilizada na etapa de restrição para gerar os dados apresentados foi a MspI. As porcentagens de variação associadas a cada componente principal (PC1 e PC2) estão indicadas nos eixos

A comunidade bacteriana presente no solo da área de monocultura da cana-de-açúcar exibiu um comportamento similar ao daquela estabelecida no solo da floresta (Figura 16). No T1, nenhuma diferença foi verificada entre as amostras em resposta à aplicação dos tratamentos. No $\mathrm{T} 6$, os perfis de T-RFLP dos solos do tratamento $\mathrm{C}_{90 \% \mathrm{CC}}$ também se diferenciam daqueles exibidos pelos solos sob os outros tratamentos. Do mesmo modo, a mudança prevaleceu até o T29. 


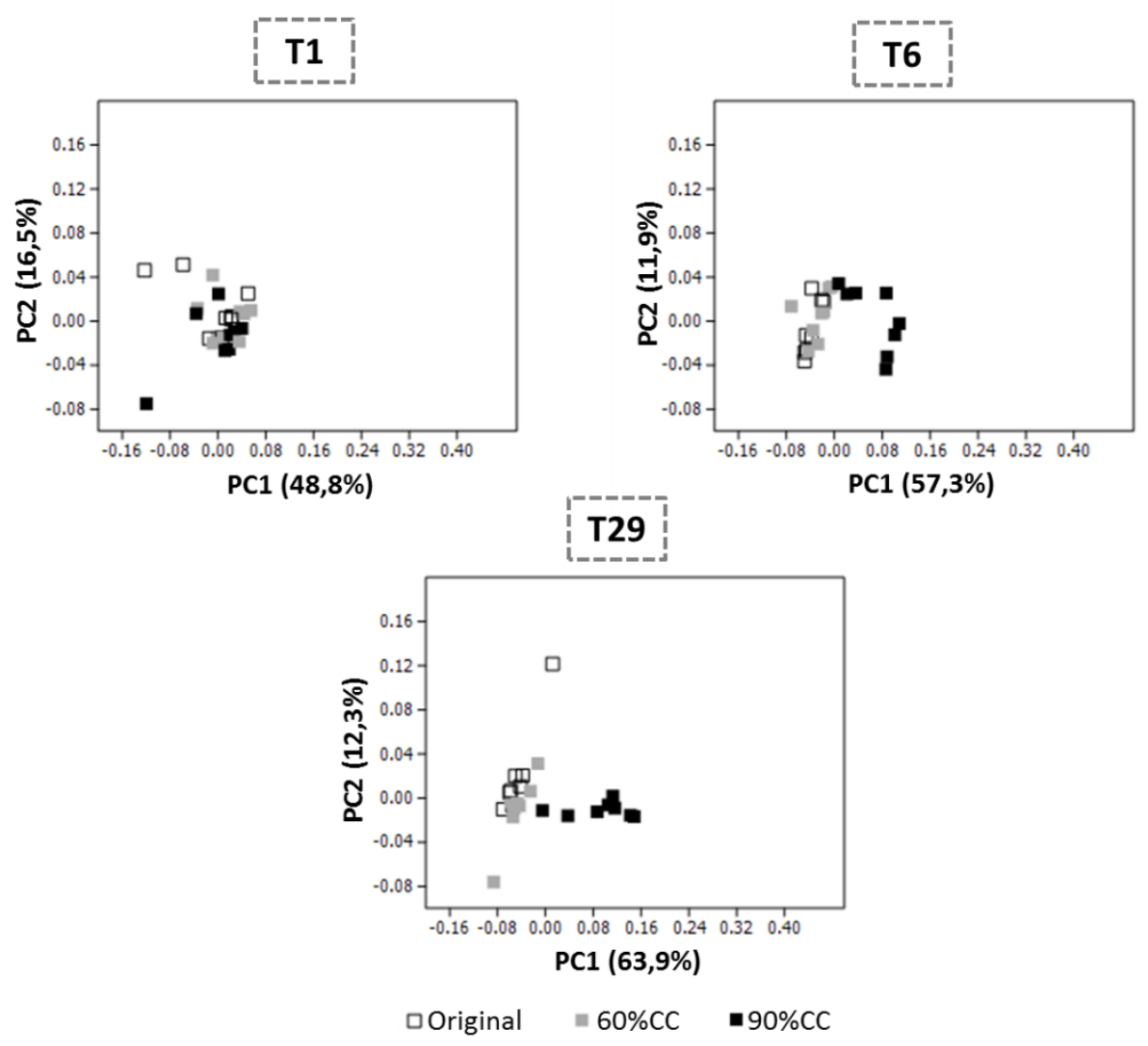

Figura 16 - Análises de Componentes Principais (PCA) das comunidades bacterianas de solos de canavial mantidos com diferentes teores de umidade, conforme indicado na legenda. Original: teor inalterado; $60 \% \mathrm{CC}$ e $90 \% \mathrm{CC}$ : solos com umidade correspondente a $60 \%$ e a $90 \%$ da capacidade de campo, respectivamente. As PCAs apresentadas baseiam-se nos dos perfis de T-RFLP do gene 16S rRNA obtidos um (T1), seis (T6) e 29 (T29) dias após a aplicação dos tratamentos. A enzima utilizada na etapa de restrição para gerar os dados apresentados foi a $M s p I$. As porcentagens de variação associadas a cada componente principal (PC1 e PC2) estão indicadas nos eixos

Considerando os solos de pastagem, o resultado obtido foi um pouco diferente, pois as comunidades não sofreram modificações tão expressivas ao longo do tempo (Figura 17). Assim como no T1, os pontos referentes aos diferentes tratamentos continuam se sobrepondo no T6, o que mostra que não houve diferenciação das comunidades em função da alteração do teor de umidade dos solos. No T29, os perfis de T-RFLP dos solos mantidos com umidade correspondente a 60 e $90 \%$ da $\mathrm{CC}$ se diferenciaram sutilmente daqueles verificados nas amostras em que o teor de umidade não foi alterado. No entanto, as diferenças não foram grandes a ponto de separar as comunidades de acordo com o tratamento e formar grupos distintos como observado para os solos coletados na floresta e no canavial. 


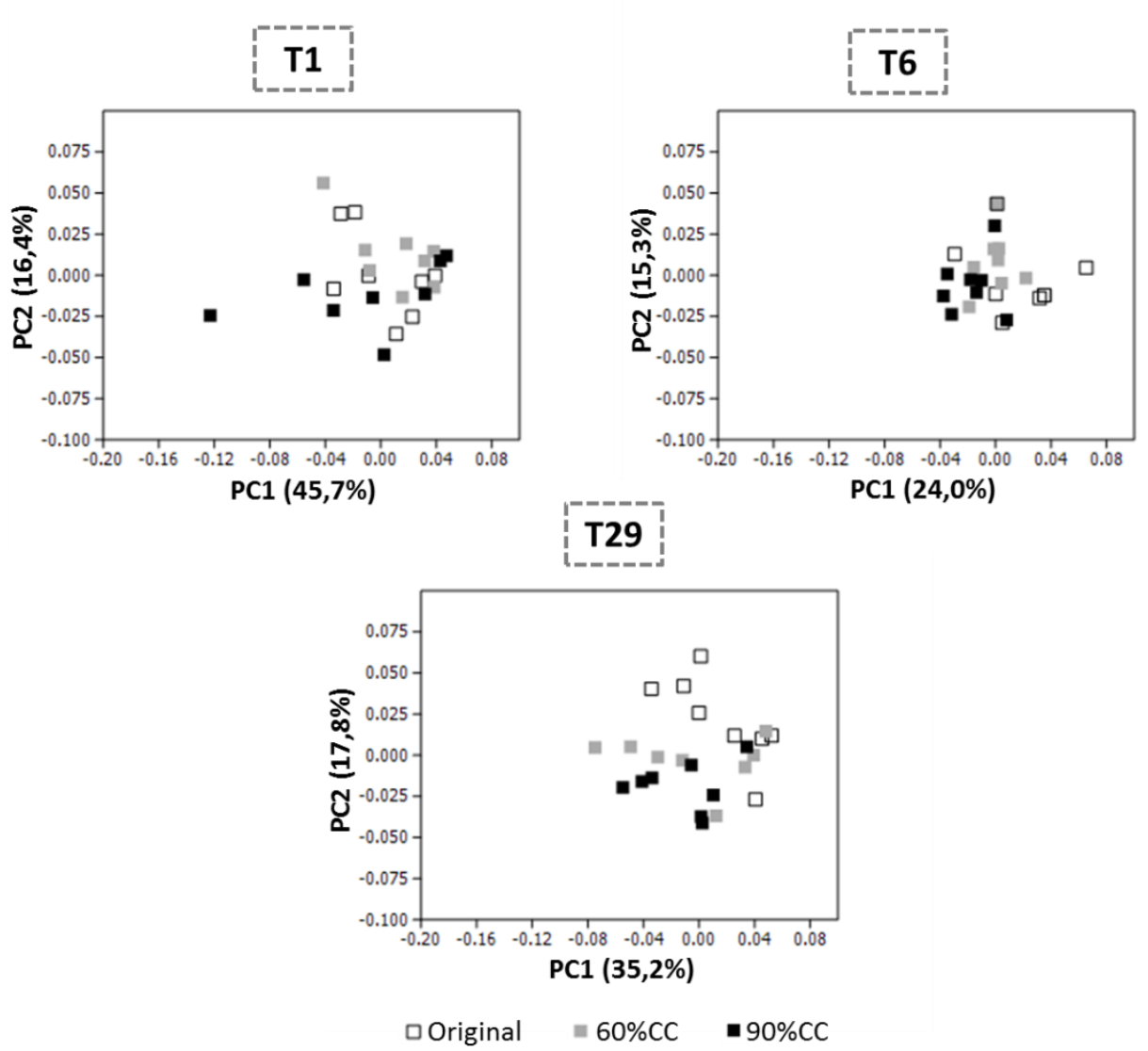

Figura 17 - Análises de Componentes Principais (PCA) das comunidades bacterianas do solos de área de pastagem mantidos com diferentes teores de umidade, conforme indicado na legenda. Original: teor inalterado; $60 \% \mathrm{CC}$ e $90 \% \mathrm{CC}$ : solos com umidade correspondente a $60 \%$ e a 90\% da capacidade de campo, respectivamente. As PCAs apresentadas baseiam-se nos dos perfis de T-RFLP do gene 16S rRNA obtidos um (T1), seis (T6) e 29 (T29) dias após a aplicação dos tratamentos. A enzima utilizada na etapa de restrição para gerar os dados apresentados foi a MspI. As porcentagens de variação associadas a cada componente principal (PC1 e PC2) estão indicadas nos eixos

Diante dos resultados obtidos através do monitoramento dos perfis de T-RFLP ao longo do período de incubação, foi possível concluir que somente os volumes de água capazes de estimular a produção de $\mathrm{N}_{2} \mathrm{O}$ pelas amostras de solo promoveram alterações em suas comunidades bacterianas. Essa diferenciação, no entanto, ocorreu de maneira tardia em relação às variações observadas no fluxo do gás.

Conforme demonstrado anteriormente, as taxas de emissão de $\mathrm{N}_{2} \mathrm{O}$ pelos solos do $\mathrm{F}_{90 \% \mathrm{CC}}, \mathrm{C}_{90 \% \mathrm{CC}}$ e $\mathrm{P}_{90 \% \mathrm{CC}}$ aumentaram de maneira expressiva no T1. Nesse ponto, contudo, as comunidades presentes nos mesmos ainda mantinham a mesma estrutura apresentada pelas amostras com menor teor de umidade, as quais não exibiram fluxos significativos 
desse gás. As primeiras modificações ocorrem somente no T6, para os solos da floresta e do canavial, e no T29, para solo da pastagem. Desse modo, coincidiram com o momento em que a produção de $\mathrm{N}_{2} \mathrm{O}$ por parte de cada um desses solos se torna inexpressiva.

$\mathrm{O}$ fato de alterações nas comunidades bacterianas não terem sido observadas no T1 não significa, necessariamente, que as mesmas não tenham ocorrido. Uma limitação da técnica de PCR, que gera os produtos a serem analisados por T-RFLP, é que ela acaba amplificando somente o DNA das espécies numericamente dominantes quando há grande quantidade de DNA molde disponível (KIRK et al., 2004). Assim, muitas vezes, não são consideradas nas análises as sequências de $16 \mathrm{~S}$ rRNA das bactérias que representam frações reduzidas da comunidade, como é o caso das desnitrificantes. Em decorrência disso, é possível que as variações sofridas pelas mesmas não tenham sido detectadas, o que demonstra a necessidade de estudá-las mais especificamente.

\subsubsection{Análise de PCR quantitativo em tempo real (qPCR)}

As condições utilizadas nas reações de qPCR permitiram amplificar os genes-alvo de maneira específica, pois as curvas de melting referentes aos amplicons gerados com os primers de $16 \mathrm{~S}$ rRNA, nirK, cnorB e nos $Z$ apresentaram picos únicos. Isso indica que cada reação levou a formação de um único tipo de produto e que, provavelmente, a quantificação dos genes de interesse não sofreu interferências decorrentes da amplificação de outros fragmentos.

Todas as reações apresentaram eficiência adequada e as curvas-padrão apresentaram coeficientes de correlação $\left(\mathrm{R}^{2}\right)$ próximos de 1 , o que significa que os dados se ajustaram bem à mesma. Assim, os resultados obtidos por meio dessa técnica podem ser considerados confiáveis.

\subsubsection{Gene 16S rRNA}

Para todas as reações de qPCR feitas com o objetivo de quantificar o gene $16 \mathrm{~S}$ rRNA, as curvas-padrão foram estabelecidas com base nas diluições seriadas contendo entre $10^{9} \mathrm{e}$ $10^{5}$ cópias do mesmo. As quantidades detectadas em todas as amostras de DNA se situaram dentro desse intervalo, pois apresentaram ordens de grandeza de $10^{6}$ e $10^{7}$. A eficiência das reações variou entre 90 e $99 \%$ e o $\mathrm{R}^{2}$ entre 0,999 e 0,998 . 
Quando os valores foram convertidos para o número de cópias do gene por grama de solo seco e a análise de variância foi realizada, verificou-se que os solos empregados no experimento apresentaram diferenças quanto à abundância do $16 \mathrm{~S}$ rRNA $(P<0,05)$. As quantificações feitas no T0, antes da aplicação dos tratamentos, revelaram que o número médio de cópias do gene foi maior nas amostras da pastagem $\left(1,21 \pm 0,1 \times 10^{10}\right.$ cópias $\mathrm{g}^{-1}$ solo seco), intermediário nas da vegetação nativa $\left(8,42 \pm 0,7 \times 10^{9}\right.$ cópias/g solo seco) e mais

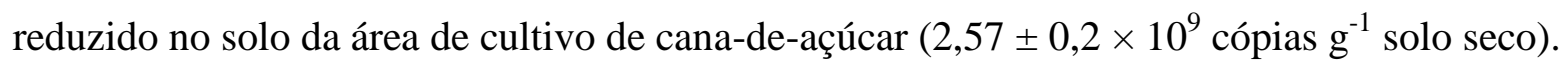

A umidade foi capaz de provocar alterações significativas na quantidade desse gene bacteriano somente no solo proveniente da pastagem. Nesse caso, a quantidade média de 16S rRNA não variou ao longo do período de incubação nas amostras mantidas com a umidade original ou $60 \%$ da umidade na $\mathrm{CC}$, mas se tornou mais abundante naquelas que receberam os maiores volumes de água (Figura 18).

Nos solos de pastagem com $90 \%$ da umidade na CC, verificou-se que o número médio de cópias do $16 \mathrm{~S}$ rRNA aumentou para $1,55 \pm 0,2 \times 10^{10}$ cópias $\mathrm{g}^{-1}$ solo seco logo no $\mathrm{T} 1$, quando se tornou maior $(P<0,05)$ do que o observado nas amostras sob os outros tratamentos. Essa média mais elevada ainda permaneceu no T6, mas ao final do experimento a abundância do gene nos solos sob este tratamento voltou a se igualar à dos demais.

Iovieno e Bååth (2008) demonstraram que a adição de água ao solo é capaz estimular a multiplicação das bactérias em poucas horas e que, depois de alguns dias, as taxas de crescimento diminuem e se estabilizam se a umidade for mantida constante. Isso explicaria o curto período de tempo necessário para o aumento na abundância desse gene bacteriano nas amostras após a elevação do teor de umidade das mesmas, bem como o fato de a comunidade não ter se expandido continuamente até o T29.

O fato de as comunidades bacterianas presentes nas amostras de solo da área de vegetação nativa e do canavial não terem se comportado da mesma maneira, indica que a resposta das mesmas depende também do modo como estão estruturadas e do meio no qual estão estabelecidas. Cabe ressaltar, que a incubação com $90 \%$ da umidade CC pode ter promovido modificações mais tardias na abundância do gene 16S rRNA nessas amostras, num período em que a análise não foi realizada (entre o T6 e o T29). No entanto, também é possível que essas comunidades tenham sofrido somente modificações estruturais, as quais foram anteriormente demonstradas através da análise de T-RFLP. 


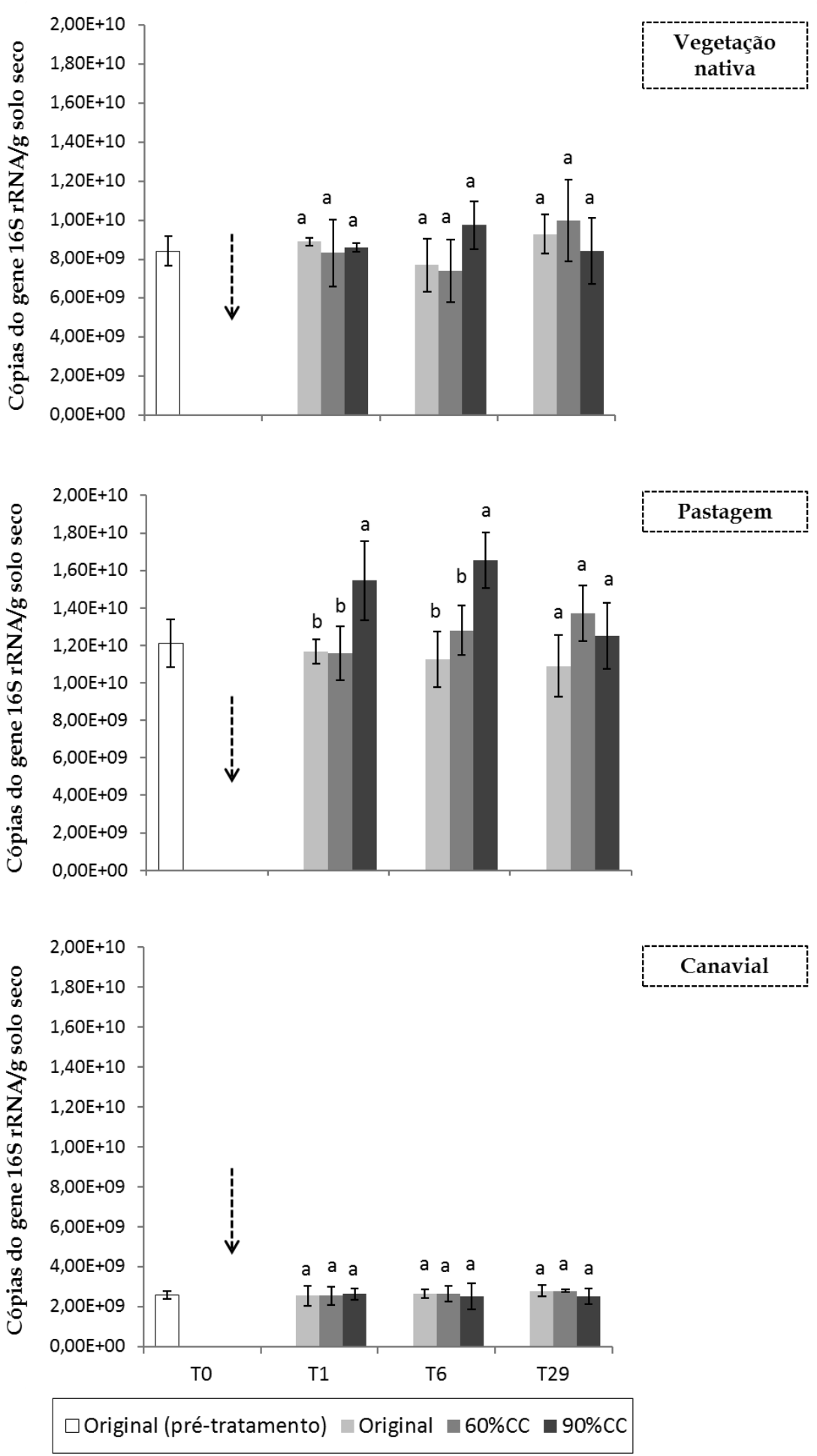

Figura 18 - Número de cópias do gene 16S rRNA nos solos de floresta, pastagem e canavial mantidos com diferentes teores de umidade em experimento de microcosmos, conforme indicado na legenda. Original: teor inalterado; 60\% CC e 90\%CC: solos com umidade correspondente a $60 \%$ e a $90 \%$ da capacidade de campo, respectivamente. Os dados foram obtidos antes (T0) e 1 (T1), 6 (T6) e 29 (T29) dias após a aplicação dos tratamentos (indicado pela seta). Os valores representam as médias e as barras o desvio padrão (T0: n=12; T1 a T29: n=4). Em cada gráfico, as médias encontradas em um mesmo dia de análise que diferiram significativamente pelo teste de Tukey $(P<0,05)$ estão acompanhadas de letras diferentes 


\subsubsection{Gene nirK}

Para as curvas-padrão, foram empregadas as diluições contendo entre $10^{7}$ e $10^{3}$ cópias do nirK, o que permitiu quantificar adequadamente o gene nas amostras de DNA. Nestas, a magnitude do número de cópias se manteve entre $10^{4}$ e $10^{5}$. A eficiência das reações variou entre 81 e $98 \%$ e o $\mathrm{R}^{2}$ entre 0,999 e 0,998 .

O gene nirK apareceu com abundâncias diferentes $(P<0,05)$ nos solos das áreas de estudo. Assim como observado para o $16 \mathrm{~S}$ rRNA, o número médio de cópias desse gene no início do experimento (T0) foi menor no solo do canavial $\left(2,29 \pm 0,2 \times 10^{7}\right.$ cópias $\mathrm{g}^{-1}$ solo seco) e maior no da pastagem $\left(2,57 \pm 0,3 \times 10^{8}\right.$ cópias $\mathrm{g}^{-1}$ solo seco). O solo de floresta também apresentou uma abundância intermediária com relação ao mesmo $\left(1,87 \pm 0,3 \times 10^{8}\right.$ cópias $\mathrm{g}^{-1}$ solo seco).

Em nenhum dos solos a abundância do nirK foi afetada pela variação do teor de umidade, pois as amostras provenientes de uma mesma área que foram submetidas a diferentes tratamentos apresentaram médias iguais $(P>0,05)$ ao longo de todo o experimento (Figura 19). Tais resultados contrastam com os de Szukics et al. (2010), que verificaram um rápido aumento na quantidade desse gene associado ao preenchimento do espaço poroso do solo por água. Essa discrepância, no entanto, torna-se compreensível quando se leva em conta que as amostras avaliadas por esses autores são diferentes das que foram utilizadas no presente estudo, e que a resposta dos grupos microbianos pode variar de maneira considerável de acordo com o ambiente no qual estão inseridos (RICH; MYROLD, 2004).

A única variação no número de cópias do nirK foi um leve aumento que pôde ser observado nos microcosmos a partir do T1, e se manteve nos outros dias em que as quantificações foram realizadas. Embora esse incremento não tenha sido grande o suficiente para diferenciar estatisticamente a abundância média desse gene em função do tempo, o mesmo se destacou pelo fato de ter ocorrido em praticamente todos os tratamentos (ou seja, foi independente do tipo de solo e do teor de umidade).

É possível que as bactérias portadoras do gene nirK tenham tido seu crescimento estimulado pela incubação sob uma temperatura mais elevada $\left(30^{\circ} \mathrm{C}\right)$ do que aquela em que o solo foi mantido durante o processamento das amostras $\left(22{ }^{\circ} \mathrm{C}\right)$, levando ao aumento generalizado da abundância do mesmo que foi observado nos microcosmos. A temperatura é um fator capaz de afetar a abundância desses organismos, sendo que já foi demonstrado, sob condições controladas de laboratório, que alguns deles têm seu desenvolvimento fortemente favorecido pelo aumento da mesma (BRAKER; SCHWARZ; CONRAD, 2010). 

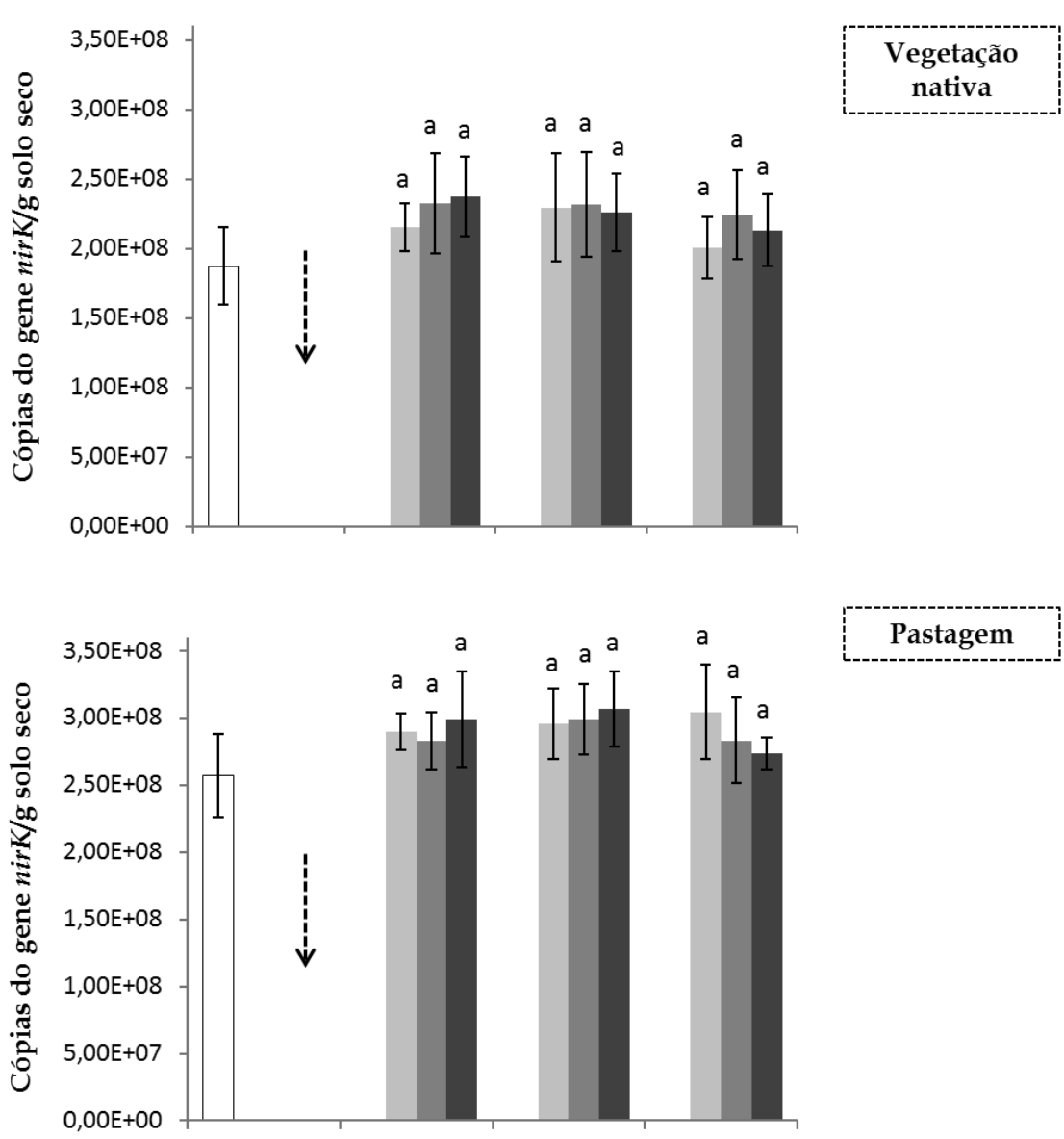

Pastagem

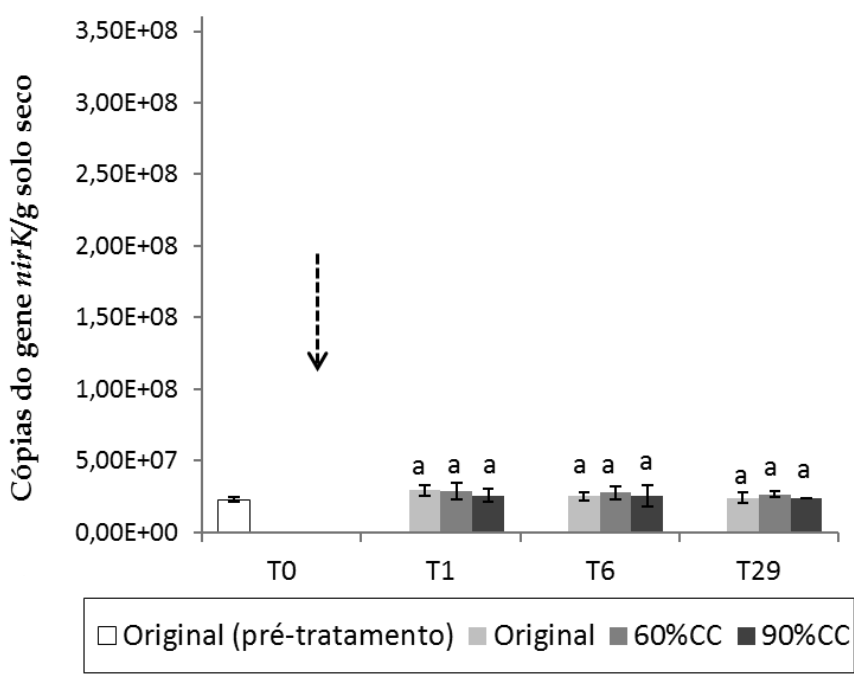

Figura 19 - Número de cópias do gene nirK nos solos de floresta, pastagem e canavial mantidos com diferentes teores de umidade em experimento de microcosmos, conforme indicado na legenda. Original: teor inalterado; $60 \% \mathrm{CC}$ e $90 \% \mathrm{CC}$ : solos com umidade correspondente a $60 \%$ e a $90 \%$ da capacidade de campo, respectivamente. Os dados foram obtidos antes (T0) e 1 (T1), 6 (T6) e 29 (T29) dias após a aplicação dos tratamentos (indicado pela seta). Os valores representam as médias e as barras o desvio padrão (T0: $n=12$; T1 a T29: n=4). Em cada gráfico, as médias encontradas em um mesmo dia de análise que diferiram significativamente pelo teste de Tukey $(P<0,05)$ estão acompanhadas de letras diferentes 


\subsubsection{Gene norB}

A ordem de grandeza do número de cópias do norB variou entre $10^{3}$ e $10^{4}$ e, portanto, se manteve dentro dos limites estabelecidos pela curva-padrão, para as quais se utilizaram as diluições contendo entre $10^{6}$ e $10^{2}$ cópias do mesmo. A eficiência das reações variou entre 91 e $95 \%$ e o $\mathrm{R}^{2}$ foi de 0,999 em todos os casos.

Esse gene também apresentou abundâncias diferentes nos solos das áreas de coleta. Repetindo o padrão encontrado para as outras quantificações no T0, o norB apareceu em maior quantidade nas amostras de pastagem $\left(9,58 \pm 1,2 \times 10^{6}\right.$ cópias $\mathrm{g}^{-1}$ solo seco), depois nas de floresta $\left(4,00 \pm 0,6 \times 10^{6}\right.$ cópias $\mathrm{g}^{-1}$ solo seco) e, por último, nas do solo cultivado com

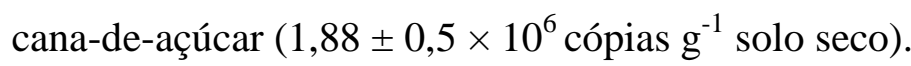

As análises realizadas após a aplicação dos tratamentos revelaram que umidade foi capaz de provocar alterações no número de cópias desse gene (Figura 20). Nos solos das três áreas de coleta, a abundância do norB nas amostras incubadas com $90 \%$ da CC se mostrou maior, pelo menos em algum momento, do que a registrada naquelas em que os teores originais foram preservados. Essa diferenciação, todavia, ocorreu com dinâmicas distintas em cada um deles.

Considerando os solos da pastagem e do canavial, foi possível observar logo no T1 que a quantidade do gene foi mais elevada nos microcosmos com os maiores teores de umidade do que nos demais. Nesse ponto, o número médio de cópias presente nas amostras vindas do pasto foi de $1,2 \pm 0,1 \times 10^{7}$ cópias $\mathrm{g}^{-1}$ solo seco e de 4,55 $\pm 0,9 \times 10^{6}$ cópias $\mathrm{g}^{-1}$ solo seco nas obtidas do cultivo de cana-de-açúcar. No T6, as médias desses solos com maior conteúdo de água voltaram a se igualar às dos solos submetidos aos outros tratamentos.

O aumento do número de cópias nos solos da área de vegetação nativa foi mais tardio. As amostras com umidade ajustada para $90 \%$ da CC só passaram a apresentar mais genes do que aquelas que não tiveram a umidade modificada no T6, quando apresentou uma média igual a 7,82 $\pm 1,9 \times 10^{6}$ cópias $\mathrm{g}^{-1}$ solo seco. Ao final do experimento, esse tratamento ainda exibia uma maior quantidade de $c n o r B$ do que os demais, com uma média de $6,95 \pm 0,7 \times 10^{6}$ cópias $\mathrm{g}^{-1}$ solo seco. 

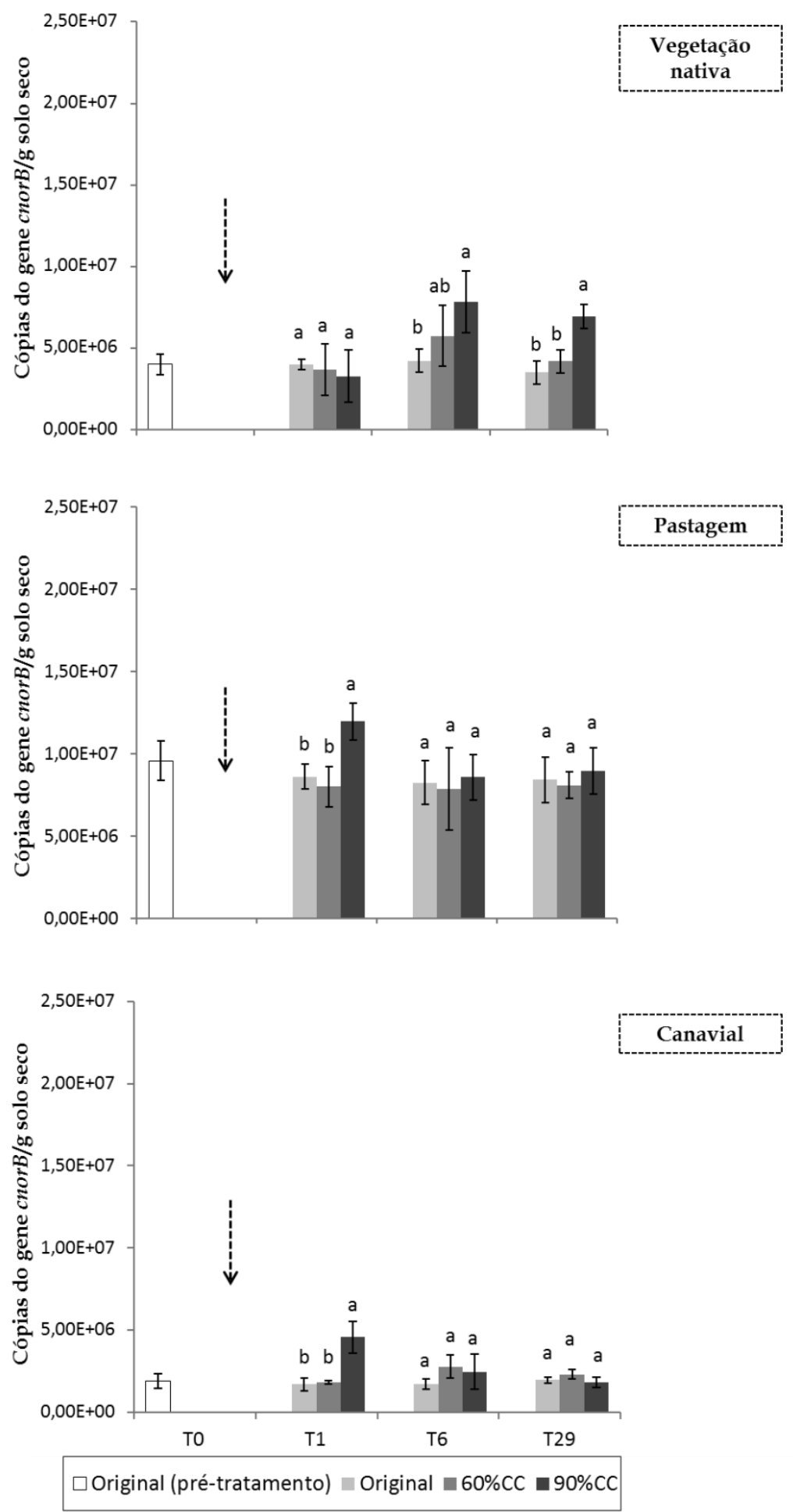

Figura 20 - Número de cópias do gene cnorB nos solos de floresta, pastagem e canavial mantidos com diferentes teores de umidade em experimento de microcosmos, conforme indicado na legenda. Original: teor inalterado; $60 \% \mathrm{CC}$ e $90 \% \mathrm{CC}$ : solos com umidade correspondente a $60 \%$ e a $90 \%$ da capacidade de campo, respectivamente. Os dados foram obtidos antes (T0) e 1 (T1), 6 (T6) e 29 (T29) dias após a aplicação dos tratamentos (indicado pela seta). Os valores representam as médias e as barras o desvio padrão (T0: n=12; T1 a T29: n=4). Em cada gráfico, as médias encontradas em um mesmo dia de análise que diferiram significativamente pelo teste de Tukey $(P<0,05)$ estão acompanhadas de letras diferentes 
Os primers utilizados no presente estudo amplificam especificamente o gene cnorB de bactérias dos gêneros Bosea, Bradyrhizobium e Ensifer e a influência da umidade sobre a abundância das mesmas ainda não havia sido relatada nos poucos estudos voltados para sua quantificação em amostras de solo (BARTON et al., 2013; DANDIE et al., 2008). Entretanto, os resultados obtidos no presente trabalho indicam a existência dessa relação, visto que em todos os solos avaliados a adição de água estimulou o crescimento desses organismos. $\mathrm{O}$ fato de os mesmos serem anaeróbios facultativos e tornarem-se aptos a utilizar o NO como aceptor de elétrons assim que o $\mathrm{O}_{2}$ se torna limitante (VAN SPANNING et al., 2007) permite que obtenham energia sob condições de maior umidade (ZUMFT, 1993), o que pode ter favorecido sua multiplicação.

\subsubsection{Gene nos $Z$}

Nas amostras de DNA, o número de cópias do gene nos $Z$ detectado variou entre $10^{4} \mathrm{e}$ $10^{6}$, e as curvas-padrão foram traçadas com base nas diluições entre $10^{7}$ e $10^{3}$ cópias do mesmo. A eficiência das reações variou entre 84 e $95 \%$ e, em todos os casos, o $R^{2}$ foi de 0,999 .

A análise de variância revelou que houve diferença significativa $(P<0,05)$ do número de cópias do gene nos $Z$ em função do solo empregado no experimento. No T0, a quantidade média encontrada nas amostras da pastagem foi de $1,15 \pm 0,2 \times 10^{8}$ cópias $\mathrm{g}^{-1}$ solo seco. Para as amostras das áreas de vegetação nativa e do canavial os valores verificados foram,

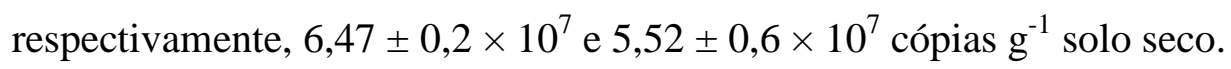

A umidade se mostrou capaz de provocar alterações expressivas na quantidade desse gene desnitrificante nos solos das três áreas de estudo (Figura 21). O aumento no número de cópias de nos $Z$ foi detectado nas amostras que receberam os maiores volumes de água, enquanto as quantidades médias encontradas nas amostras em que a umidade original foi mantida não se modificaram ao longo do experimento. No T29, a abundância do nosZ se mostrou um pouco maior nos solos do canavial com umidade ajustada para $60 \%$ da CC do que nas amostras que não tiveram seus teores de umidade alterados, mas isso não foi observado nas amostras de solo da floresta e da pastagem. 

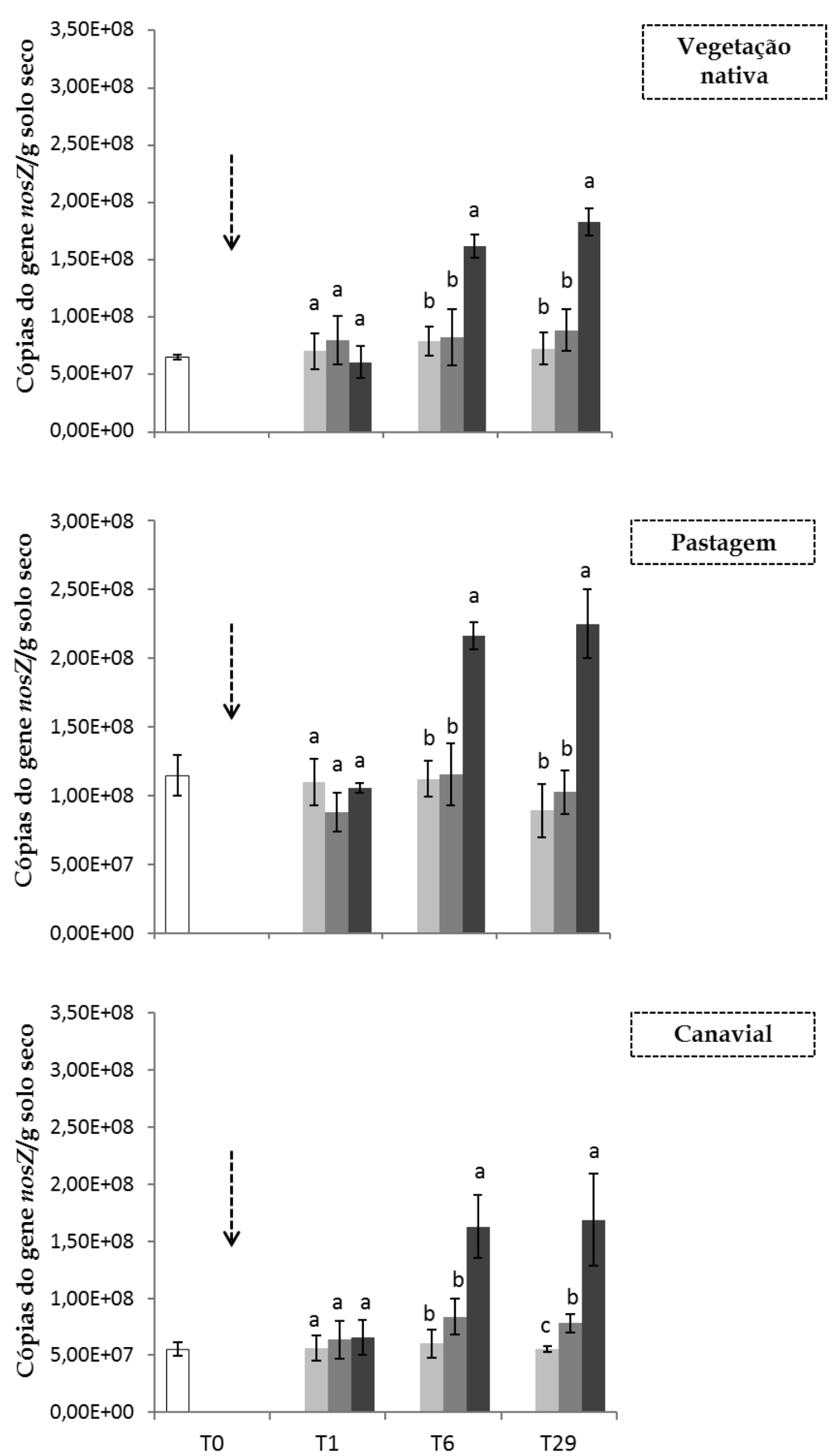

$\square$ Original (pré-tratamento) $\square$ Original $\square 60 \%$ CC $\square 90 \%$ CC

Figura 21 - Número de cópias do gene nosZ nos solos de floresta, pastagem e canavial mantidos com diferentes teores de umidade em experimento de microcosmos, conforme indicado na legenda. Original: teor inalterado; $60 \% \mathrm{CC}$ e $90 \% \mathrm{CC}$ : solos com umidade correspondente a $60 \%$ e a $90 \%$ da capacidade de campo, respectivamente. Os dados foram obtidos antes (T0) e 1 (T1), 6 (T6) e 29 (T29) dias após a aplicação dos tratamentos (indicado pela seta). Os valores representam as médias e as barras o desvio padrão (T0: n=12; T1 a T29: n=4). Em cada gráfico, as médias encontradas em um mesmo dia de análise que diferiram significativamente pelo teste de Tukey $(P<0,05)$ estão acompanhadas de letras diferentes 
Nos solos com $90 \%$ da umidade na capacidade de campo, incrementos significativos na quantidade do gene $\operatorname{nos} Z$ foram observados somente a partir do T6, pois no T1 as médias ainda permaneciam iguais às observadas antes da aplicação do tratamento. No solo de vegetação nativa, o número de cópias encontrado em cada grama de solo seco passou de $6,08 \pm 1,4 \times 10^{7}$ no T1 para 1,62 $\pm 0,1 \times 10^{8}$ T6. No solo do canavial, o aumento foi de $6,59 \pm 1,5 \times 10^{7}$ para $1,63 \pm 0,3 \times 10^{8}$ e no da pastagem, de $1,06 \pm 0,0 \times 10^{8}$ para $2,17 \pm 0,1 \times 10^{8}$. Em todos esses casos, as médias mais elevadas ainda puderam ser observadas ao final do experimento, no T29.

O fato de as bactérias que carregam o gene nosZ presentes nos diferentes solos terem respondido da mesma maneira ao aumento do teor de umidade, sugere a existência de uma forte relação entre esta variável ambiental e a abundância deste grupo de organismos. Stres et al. (2008) também relataram a diferenciação dessas populações desnitrificantes em função do conteúdo de água; porém, nas amostras de solo avaliadas por estes autores, as mudanças ocorreram de modo sutil e não se mostraram significativas do ponto de vista estatístico.

As condições de alta umidade e temperatura - encontradas nos microcosmos com $90 \%$ da $\mathrm{CC}$ incubados a $30{ }^{\circ} \mathrm{C}$ - podem ter criado um ambiente favorável à mineralização da MO, bem como à solubilização e à difusão de substâncias até os nichos ocupados por essas bactérias, favorecendo o seu crescimento (BOWDEN, 1986). Já foi demonstrado, por exemplo, que o aumento na disponibilidade de $\mathrm{C}$ pode levar a incrementos expressivos na abundância do nosZ em amostras de solo (HENDERSON et al., 2010).

O aumento no número de cópias desse gene coincidiu com a diminuição das taxas de emissão de $\mathrm{N}_{2} \mathrm{O}$ a partir das amostras da floresta e do canavial, sendo ambos registrados no T6. A correlação negativa entre o número de cópias de nosZ e a produção deste GEE já foi verificada em outros estudos (PHILIPPOT et al., 2009; PHILIPPOT et al., 2011). Isso indica que, além de ter aumentado quanto à abundância, este gene pode ter se tornado mais ativo e contribuído para reduzir esse gás a $\mathrm{N}_{2}$. A transcrição do nos $Z$ é ativada algumas horas depois de as condições se tornarem anóxicas, sendo induzida tanto pela depleção de $\mathrm{O}_{2}$ quanto pelo aumento da concentração de NO (BERGAUST et al., 2012). 


\subsubsection{Correlações entre as variáveis}

Através do cálculo dos coeficientes de correlação, foram identificadas as conexões existentes entre os atributos físico-químicos e o número de cópias dos genes $16 \mathrm{~S}$ rRNA, nirK, cnorB e nosZ dos solos utilizados no experimento. Os resultados dessa análise estão representados na tabela 4 .

Todos os genes apresentaram correlações positivas com os teores de $\mathrm{MO}, \mathrm{C}, \mathrm{N}, \mathrm{NH}_{4}{ }^{+} \mathrm{e}$ $\mathrm{NO}_{3}{ }^{-}$. De maneira geral, a MO pode contribuir com o desenvolvimento dos microrganismos do solo porque é formada por compostos que os mesmos utilizam como fonte de energia e nutrientes nos processos de biossíntese de seus componentes celulares (MENDONÇA; LEITE, 2006). Por ser um estoque importante de C e N, a MO também influencia a disponibilidade desses elementos no solo, os quais são reconhecidamente capazes de estimular não só a atividade, mas também a proliferação dos organismos desnitrificantes, conforme já foi demonstrado em outros trabalhos (GROFFMAN; TIEDJE, 1989; TIEDJE, 1988; WALLENSTEIN et al., 2006).

A abundância dos genes também se mostrou associada à textura do solo, pois todos eles apresentaram correlações negativas com os teores de areia e positivas com as quantidades de silte e argila. Em geral, solos argilosos conseguem manter um nível de umidade maior do que os arenosos (MCTAGGART et al., 2002), o que favorece a atividade e o crescimento microbiano e, portanto, pode estimular o adensamento de suas comunidades (IOVIENO; BÅÅTH, 2008). Além disso, a capacidade de reter maiores volumes de água confere aos solos uma maior disponibilidade de nichos isentos de $\mathrm{O}_{2}$ (TIEDJE et al., 1984), e o fato de os organismos desnitrificantes apresentarem a vantagem de poder ocupá-los, por serem anaeróbios facultativos, pode ter contribuído para a multiplicação dos mesmos nos solos com maiores conteúdos de partículas finas.

$\mathrm{O}$ pH se correlacionou negativamente com o número de cópias dos genes quantificados, exceto no caso do nos $Z$, para o qual essa correlação não foi significativa. Isso contrasta com a ideia geralmente aceita de que as bactérias são capazes de se desenvolver melhor em condições mais próximas da neutralidade (BÅÅTH; FROSTEGARD; FRITZE, 1992), o que também já foi verificado para os grupos desnitrificantes (CUHEL et al., 2010). Assim, pode ser que a maior abundância de $16 \mathrm{~S}$ rRNA, e de genes associados ao processo de desnitrificação observada nos solos mais ácidos (floresta e pastagem) tenha ocorrido ao acaso, 
pelo fato de o $\mathrm{pH}$ mais elevado ter sido verificado justamente na área de monocultura da canade-açúcar, onde vários outros parâmetros assumiram valores desfavoráveis ao crescimento destes microrganismos.

De acordo com os dados coletados ao longo do experimento de microcosmos (Tabela 5), verificou-se que a umidade se relacionou de maneira positiva com as taxas de emissão de $\mathrm{N}_{2} \mathrm{O}$ e com a abundância do gene nosZ, enquanto para os demais essa associação não foi significativa. Isso ocorreu provavelmente porque as variações no número de cópias do $16 \mathrm{~S}$ rRNA e do cnorB sofreram em função da umidade foram mais sutis e não ocorreram em todas as amostras, como foi verificado para o gene nosZ.

Nas amostras de solo da floresta e do canavial em que a umidade foi ajustada para 90\% da CC, o aumento na quantidade de nosZ, responsável por reduzir o $\mathrm{N}_{2} \mathrm{O}$ a $\mathrm{N}_{2}$, foi concomitante à redução das taxas de produção do GEE (ambos observados no T6). Entretanto, a correlação negativa entre essas duas variáveis não foi significativa, o que mostra que a mesma não se ajustou ao modelo linear utilizado. 
Tabela 4 - Correlações entre a abundância de genes e variáveis ambientais em amostras de solo de floresta, pastagem e cultivo de cana-de-açúcar utilizadas em experimento de microcosmos

\begin{tabular}{lccccccccc}
\hline & $\mathbf{M O}$ & $\mathbf{C}$ & $\mathbf{N}$ & $\mathbf{N H}_{\mathbf{4}}{ }^{+}$ & $\mathbf{N O}_{\mathbf{3}}{ }^{-}$ & $\mathbf{p H}$ & Areia & Silte & Argila \\
\cline { 2 - 9 } 16S rRNA & 0,54 & 0,57 & 0,59 & 0,61 & 0,61 & $-0,51$ & $-0,71$ & 0,83 & 0,64 \\
nirK & 0,69 & 0,71 & 0,73 & 0,74 & 0,75 & $-0,65$ & $-0,64$ & 0,78 & 0,54 \\
norB & 0,27 & 0,30 & 0,32 & 0,34 & 0,34 & $-0,24$ & $-0,69$ & 0,74 & 0,64 \\
nosZ & 0,17 & 0,18 & 0,19 & 0,20 & 0,20 & $n . s$. & $-0,32$ & 0,35 & 0,29 \\
\hline n.s. coeficiente de correlação de Pearson entre as variáveis não significativo $(P<0,05)$ MO: matéria orgânica; C: \\
Carbono total; N: Nitrogênio total; $\mathrm{NH}_{4}^{+}$: amônio; $\mathrm{NO}_{3}^{-}$: nitrato; $\mathrm{pH}$ : potencial hidrogeniônico (em água).
\end{tabular}

Tabela 5 - Correlações entre a abundância de genes, umidade e fluxos de $\mathrm{N}_{2} \mathrm{O}$ em amostras de solo de floresta, pastagem e cultivo de cana-de-açúcar mantidas com diferentes teores de umidade em experimento de microcosmos

\begin{tabular}{lccc}
\hline & Umidade & $\begin{array}{c}\mathbf{N}_{2} \mathbf{O} \\
\text { (fluxo) }\end{array}$ & $\begin{array}{c}\mathbf{N}_{2} \mathbf{O} \\
\text { (cumulativo) }\end{array}$ \\
\cline { 2 - 4 } nirK rRNA & $n . s$ & $n . s$. & 0,34 \\
norB & $n . s$ & $n . s$. & 0,33 \\
nosZ & $n . s$ & $n . s$. & 0,47 \\
$\mathbf{N}_{\mathbf{2}} \mathbf{O}$ (fluxo) & 0,49 & $n . s$. & 0,49 \\
$\mathbf{N}_{\mathbf{2}} \mathbf{O}$ (cumulativo) & 0,35 & - & $n . s$. \\
\hline
\end{tabular}

n.s. coeficiente de correlação de Pearson entre as variáveis não significativo $(P<0,05)$. $\mathrm{N}_{2} \mathrm{O}$ (fluxo): taxa de emissão de $\mathrm{N}_{2} \mathrm{O} ; \mathrm{N}_{2} \mathrm{O}$ (cumulativo): quantidade total de $\mathrm{N}_{2} \mathrm{O}$ emitida ao longo do período de incubação. 


\section{CONCLUSÕES}

Com base nos resultados obtidos foi possível concluir que somente o ajuste da umidade dos solos para $90 \%$ da CC, uma condição que favorece a ocorrência do processo de desnitrificação, foi capaz de alterar as taxas de emissão de $\mathrm{N}_{2} \mathrm{O}$, as comunidades bacterianas e a abundância dos genes $\operatorname{cnor} B$ e nos $Z$ nas amostras das áreas de vegetação nativa, floresta e cultivo de cana-de-açúcar. O gene nirK não teve sua abundância alterada em função do teor de umidade nos solos avaliados e o número de cópias do gene 16S rRNA variou apenas no solo da pastagem.

Nas amostras das três áreas de coleta, o gene nosZ sofreu os maiores incrementos após o ajuste da umidade, sendo o único gene a apresentar uma correlação positiva com o conteúdo de água do solo. Embora o aumento do mesmo tenha se dado no momento em que as taxas de emissão de $\mathrm{N}_{2} \mathrm{O}$ diminuíram nos solos da vegetação nativa e do canavial, a correlação negativa entre essas duas variáveis não foi significativa.

Sendo assim, as taxas de emissão de $\mathrm{N}_{2} \mathrm{O}$ não se correlacionaram com a abundância dos genes analisados e, provavelmente, foram afetadas pelo aumento do teor de umidade do solo simplesmente porque isso reduz a disponibilidade de $\mathrm{O}_{2}$ e estimula a atividade dos organismos envolvidos na sua produção. Por outro lado, as emissões cumulativas desse gás foram maiores nos solos em que os genes desnitrificantes apareceram com maior abundância inicial.

Todos os genes quantificados apresentaram correlações positivas com os teores de MO, $\mathrm{C}, \mathrm{N}, \mathrm{NO}_{3}{ }^{-}$e argila, o que condiz com os resultados de outros trabalhos que demonstram que esses fatores podem influenciar o desenvolvimento dos organismos que os carregam e, portanto, a estruturação das comunidades desnitrificantes. Essas propriedades podem ser afetadas pelas mudanças de uso do solo e pela intensidade do mesmo.

Nas amostras provenientes da área de cultivo de cana-de-açúcar, verificou-se uma menor riqueza de UTO's e abundância de bactérias, o que parece ter se refletido na abundância de genes desnitrificantes, que também foram encontrados em menores quantidades. Aparentemente, o uso mais intensivo do solo, típico de áreas destinadas à produção agrícola, provocou alterações drásticas nas propriedades físico-químicas do mesmo, afetando negativamente o processo de desnitrificação, o qual é um importante componente do ciclo biogeoquímico do $\mathrm{N}$. 


\section{REFERÊNCIAS}

BÅÅTH, E.; FROSTEGARD, A.; FRITZE, H. Soil bacterial biomass, activity, phospholipid fatty acid pattern, and $\mathrm{pH}$ tolerance in an area polluted with alkaline dust deposition. Applied and Environmental Microbiology, Washington, DC, v. 58, n. 12, p. 4026-4031, 1992.

BAIRD, C. Química ambiental. Porto Alegre: Bookman, 2002. 622 p.

BAKKEN, L. R.; BERGAUST, L.; LIU, B.; FROSTEGÅRD, Å. Regulation of denitrification at the cellular level: a clue to the understanding of $\mathrm{N}_{2} \mathrm{O}$ emissions from soils. Philosophical Transactions of the Royal Society B, London, v. 367, p. 1226-1234, 2012.

BARBERÁN, A.; RAMIREZ, K. S.; LEFF, J. W.; BRADFORD, M. A.; WALL, D. H.; FIERER, N. Why are some microbes more ubiquitous than others? Predicting the habitat breadth of soil bacteria. Ecology Letters, Malden, v. 17, p. 794-802, 2014.

BARTON, L.; GLEESON, D. B.; MACCARONE, L. D.; ZÚÑIGA L. P.; MURPHY, D. V. Is liming soil a strategy for mitigating nitrous oxide emissions from semi-arid soils? Soil Biology \& Biochemistry, Oxford, v. 62, p. 28-35, 2013.

BERGAUST, L.; VAN SPANNING, R. J. M.; FROSTEGÅRD, A.; BAKKEN, L. R. Expression of nitrous oxide reductase in Paracoccus denitrificans is regulated by oxygen and nitric oxide through FnrP and NNR. Microbiology, Reading, v. 158, p. 826-834, 2012.

BLACKMER, A. M; BREMNER, J. M. Inhibitory effect of nitrate on reduction of $\mathrm{N}_{2} \mathrm{O}$ to $\mathrm{N}_{2}$ by soil microorganisms. Soil Biology \& Biochemistry, Oxford, v. 10, p. 187-191, 1978.

BOWDEN, W. Gaseous nitrogen emissions from undisturbed terrestrial ecosystems: an assessment of their impacts on local and global nitrogen budgets. Biogeochemistry, Dordrecht, v. 2, p. 249-279, 1986.

BOX, G. E. P.; COX, D. R. An analysis of transformations. Journal of the Royal Statistical Society. Series B - Methodological, London, v. 26, n. 2, p. 211-252, 1964.

BRAKER, G.; CONRAD, R. Diversity, structure, and size of $\mathrm{N}_{2} \mathrm{O}$-producing microbial communities in soils - What matters for their functioning? Advances in Applied Microbiology, New York, v. 75, p. 33-70, 2011.

BRAKER, G.; FESEFELDT, A.; WITZEL, K-P. Development of PCR primer systems for amplification of nitrite reductase genes (nirK and nirS) to detect denitrifying bacteria in environmental samples. Applied and Environmental Microbiology, Washington, DC, v. 64, n. 10, p. 3769-3775, 1998.

BRAKER, G.; SCHWARZ, J.; CONRAD, R. Influence of temperature on the composition and activity of denitrifying soil communities. FEMS Microbiology Ecology, Amsterdam, v. 73, p. 134-148, 2010.

BRAKER, G.; TIEDJE, J. M. Nitric oxide reductase (nor B) genes from pure cultures and environmental samples. Applied and Environmental Microbiology, Washington, DC, v. 69, p. 3476-3483, 2003. 
BRODY, J. R.; KERN, S. E. Sodium boric acid: atriz-less, cooler conductive medium for DNA electrophoresis. BioTechniques, Natick, v. 36, p. 214-216, 2004.

CAVIGELLI, M. A.; ROBERTSON, G.P. The functional significance of denitrifier community composition in a terrestrial ecosystem. Ecology, Washington, DC, v. 81. n. 5, p. 1402-1414, 2000.

CHENEBY D.; HALLET, S.; MONDON, M.; MARTIN-LAURENT, F.; GERMON, J. C.; PHILIPPOT, L. Genetic characterization of the nitrate reducing community based on narG nucleotide sequence analysis. Microbial Ecology, New York, v. 46, p.113-121, 2003.

CLARK, F. E. Losses of nitrogen accompanying nitrification. Transactions of the International Society of Soil Science. Communications IV and V, Bangor, Wales, p. 173176, 1962.

CUHEL, J.; SIMEK, M.; LAUGHLIN, R. J.; BRU, D.; CHÈNEBY, D.; WATSON, C. J.; PHILIPPOT, L. Applied and Environmental Microbiology, Washington, DC, v. 76, n. 6, p. 1870-1878, 2010.

CULMAN, S. W.; GAUCH, H. G.; BLACKWOOD, C. B.; THIES, J. E. Analysis of T-RFLP data using analysis of variance and ordination methods: A comparative study. Journal of Microbiological Methods, Amsterdam, v. 75, p. 55-63, 2008.

DANDIE, C. E.; BURTON, D. L.; ZEBARTH, B. J.; HENDERSON, S. L.; TREVORS, J. T.; GOYER, C. Changes in bacterial denitrifier community abundance over time in an agricultural field and their relationship with denitrification activity. Applied and Environmental Microbiology, Washington, DC, v. 74, p. 5997-6005, 2008.

DANDIE, C. E.; MILLER, M. N.; BURTON, D. L.; ZEBARTH, B. J.; TREVORS, J. T.; GOYER, C. Nitric oxide reductase-targeted real-time PCR quantification of denitrifier populations in soil. Applied and Environmental Microbiology, Washington, DC, v. 73, p. 4250-4258, 2007.

DAVIDSON, E. A. Sources of nitric oxide and nitrous oxide following wetting of dry soil. Soil Science Society of America Journal, Madison, v. 56, p. 95-102, 1992.

DE KLEIN, C. A. M.; VAN LOGTESTIJN, R. S. P. Denitrification in grassland soils in The Netherlands in relation to irrigation, $\mathrm{N}$-application rate, soil water content and soil temperature. Soil Biology \& Biochemistry, Oxford, v. 28, p. 231-237, 1996.

DOBBIE, K. E; MCTAGGART, I. P.; SMITH, K. A. Nitrous oxide emissions from intensive agricultural systems: variations between crops and seasons, key driving variables, and mean emission factors. Journal of Geophysical Research-Atmospheres, Washington, DC, v. 104, n. D21, p. 26891-26899, 1999.

ELLER, G.; KRÜGER, M.; FRENZEL, P. Comparing field and microcosm experiments: a case study on methano- and methylo-trophic bacteria in paddy soil. FEMS Microbiology Ecology, Amsterdam, v. 51, p. 279-291, 2005. 
EMBRAPA. Manual de métodos de análise de solo. Rio de Janeiro: Embrapa Solos, 1979. $271 \mathrm{p}$.

EMBRAPA. Sistema brasileiro de classificação de solos. 2. ed. Rio de Janeiro: Embrapa Solos, 2006. 306p.

FERREIRA, D. F. SISVAR - Sistema de análise de variância. Versão 5.3. Lavras: UFLA, 2010 .

FIERER, N. Microbial biogeography: patterns in microbial diversity across space and time. In: ZENGLER, K. (Ed.). Accessing uncultivated microorganisms: from the environment to organisms and genomes and back. Washington, DC: ASM Press, 2008. p. 95-115.

FRANKLIN, R. B.; MILLS, A. L. Multi-scale variation in spatial heterogeneity for microbial community structure in an eastern Virginia agricultural field. FEMS Microbiology Ecology, Amsterdam, v. 44, p. 335-346, 2003.

FUHRMAN, J. A., CAMPBELL, L. Microbial microdiversity. Nature, London, v. 393, p. 410-411, 1998.

GRANLI, T.; BØCKMAN, O. C. Nitrous oxide from agriculture. Norwegian Journal of Agricultural Sciences, Cambridge, Supplement n. 12, p. 1-128, 1994.

GROFFMAN, P. M.; TIEDJE, J. M. Denitrification in north temperate forest soils: relationships between denitrification and environmental factors at the landscape scale. Soil Biology \& Biochemistry, Oxford, v. 21, p. 621-626, 1989.

GRÜNTZIG, V.; STRES, B.; AYALA DEL RIO, H. L.; TIEDJE, J. M. Improved protocol for T-RFLP by capillary electrophoresis. East Lansing: Ribosomal Database Project, Michigan State University, 2002. Disponível em: http://rdp.cme.msu.edu/html/trflp_jul02.html. Acesso em: 18 set. 2007.

HAMMER, Ø.; HARPER, D. A. T.; RYAN, P. D. PAST: Paleontological statistics software package for education and data analysis. Palaeontologia Electronica, Boulder, v. 4, n. 1, art. 4, 9 p., 2001. Disponível em: http://palaeo-electronica.org/2001_1/past/past.pdf.

HARMS, G.; LAYTON, A. C.; DIONISI, H. M.; GREGORY, I. R.; GARRETT, V. M.; HAWKINS, S. A.; ROBINSON, K. G.; SAYLER, G. S. Real-time PCR quantification of nitrifying bacteria in a municipal wastewater treatment plant. Environmental Science and Technology, Easton, v. 37, p. 343-351, 2003.

HARTER, J.; KRAUSE, H.; SCHUETTLER, S.; RUSER, R.; FROMME, M.; SCHOLTEN, T.; KAPPLER, A.; BEHRENS, S. Linking $\mathrm{N}_{2} \mathrm{O}$ emissions from biochar-amended soil to the structure and function of the N-cycling microbial community. The ISME Journal, London, v. 8, p. 1-15, 2013. 
HENDERSON, S. L.; DANDIE, C. E.; PATTEN, C. L.; ZEBARTH, B. J.; BURTON, D. L.; TREVORS, J. T.; GOYER, C. Changes in denitrifier abundance, denitrification gene mRNA levels, nitrous oxide emissions, and denitrification in anoxic soil microcosms amended with glucose and plant residues. Applied and Environmental Microbiology, Washington, DC, v. 76, n. 7, p. 2155-2164, 2010.

HENRY, S.; BRU, D.; STRES, B.; HALLET, S.; PHILIPPOT, L. Quantitative detection of the nos $Z$ gene, encoding nitrous oxide reductase, and comparison of the abundances of $16 \mathrm{~S}$ rRNA, narG, nirK, and nosZ genes in soils. Applied and Environmental Microbiology, Washington, DC, v. 72, p. 5181-5189, 2006.

HEUER, H.; KRSEK, M.; BAKER, P.; SMALLA, K.; WELLILNGTON, E. M. H. Analysis of actinomycete communities by specific amplification of genes encoding 16S rRNA and gelelectrophoresis separation in denaturing gradients. Applied and Environmental Microbiology, Washington, DC, v. 63, p. 3233-3241, 1997.

HIGUCHI, R.; DOLLINGER, G.; WALSH, P.S.; GRIFFITH, R. Simultaneous amplification and detection of specific DNA-sequences. Nature Biotechnology, New York, v. 10, n. 4, p. 413-417, 1992.

HIGUCHI, R.; FOCKLER, C.; DOLLINGER, G.; WATSON, R. Kinetic PCR analysis: realtime monitoring of DNA amplification reactions. Nature Biotechnology, New York, v. 11, p. 1026-1030, 1993.

HOLTAN-HARTWIG, L.; DORSCH, P.; BAKKEN L. R. Comparison of denitrifying communities in organic soils: kinetics of $\mathrm{NO}_{3}{ }^{-}$and $\mathrm{N}_{2} \mathrm{O}$ reduction. Soil Biology \& Biochemistry, Oxford, v. 32, p. 833-843, 2000.

HUGHES, J. B.; HELLMANN, J. J.; RICKETTS, T. H.; BOHANNAN, B. J. M. Counting the uncountable: statistical approaches to estimating microbial diversity. Applied and Environmental Microbiology, Washington, DC, v. 67, p. 4399-4406, 2001.

IOVIENO, P.; BÅÅTH, E. Effect of drying and rewetting on bacterial growth rates in soil. FEMS Microbiology Ecology, Amsterdam, v. 65, p. 400-407, 2008.

IPCC. Climate Change 2007: Synthesis Report. Contribution of Working Groups I, II and III to the Fourth Assessment Report of the Intergovernmental Panel on Climate Change. Cambridge: Cambridge University Press, 2007.

JANGID, K.; WILLIAMS, M. A.; FRANZLUEBBERS, A. J.; SANDERLIN, J. S.; REEVES, J. H.; JENKINS, M. B.; ENDALE, D. M.; COLEMAN, D. C.; WHITMAN, W. B. Relative impacts of land-use, management intensity and fertilization upon soil microbial community structure in agricultural systems. Soil Biology \& Biochemistry, Oxford, v. 40, p. 2843-2853, 2008.

JOHNSON, D. E. Applied multivariate methods for data analysts. 1. ed. Pacific Grove: Duxbury Press, 1998. 
KANDELER, E.; DEIGLMAYR, K.; TSCHERKO, D.; BRU, D.; PHILIPPOT, L. Abundance of narG, nirS, nirK, and nosZ genes of denitrifying bacteria during primary successions of a glacier foreland. Applied and Environmental Microbiology, Washington, DC, v. 72, p. 5957-5962, 2006.

KIRK, J. L.; BEAUDETTEA, L. A.; HARTB, M.; MOUTOGLISC, P.; KLIRONOMOSB, J. N.; LEEA, H.; TREVORSA, J. T. Methods of studying soil microbial diversity. Journal of Microbiological Methods, Amsterdam, v. 58, p. 169-188, 2004.

KUBISTA, M.; ANDRADE, J. M.; BENGTSSON, M.; AMIN FOROOTAN, A.; JONÁK, J.; LIND, K.; SINDELKA, R.; SJÖBACK, R.; SJÖGREEN, B.; STRÖMBOM, L.; ANDERS STÅHLBERG, A.; ZORIC, N. The real-time polymerase chain reaction. Molecular Aspects of Medicine, Oxford, v. 27, p. 95-125, 2006.

LIU, W. T.; MARSH, T. L.; CHENG, H.; FORNEY, L. J. Characterization of microbial diversity by determining terminal restriction fragment length polymorphisms of genes encoding 16S rRNA. Applied and Environmental Microbiology, Washington, DC, v. 63, 4516- 4522, 1997.

MANZATTO, C. V.; ASSAD, E. D.; BACCA, J. F. M.; ZARONI, M. J.; PEREIRA, S. E. M. Zoneamento agroecológico da cana-de-açúcar: expandir a produção, preservar a vida, garantir o futuro. Rio de Janeiro: Embrapa Solos, 2009. 55 p. (Documentos, 110).

MARCHESI, J. R.; SATO, T.; WEIGHTMAN, A. J.; MARTIN, T. A.; FRY, J. C.; HIOM, S. J.; DYMOCK, D.; WADE, W. G. Design and evaluation of useful bacterium-specific PCR primers that amplify genes coding for bacterial 16S rRNA. Applied and Environmental Microbiology, Washington, DC, v. 64, n. 2, p. 795-799, 1998.

MARSH, T. L. Terminal restriction fragment length polymorphism (T-RFLP): an emerging method for characterizing diversity among homologous populations of amplification products. Current Opinion in Microbiology, London, v. 2, p. 323-327, 1999.

MARSH, T. L.; SAXMAN, P.; COLE, J.; TIEDJE, J. Terminal restriction fragment length polymorphism analysis program, a web-based research tool for microbial community analysis. Applied and Environmental Microbiology, Washington, DC, v. 66, p. 3616-3620, 2000 .

MCTAGGART, I. P.; AKIYAMA, H.; TSURUTA, H.; BALL, B. C. Influence of soil physical properties, fertiliser type and moisture tension on $\mathrm{N}_{2} \mathrm{O}$ and $\mathrm{NO}$ emissions from nearly saturated Japanese upland soils. Nutrient Cycling in Agroecosystems, The Hague, v. 63, p. 207-217, 2002.

MENDONÇA, E. S.; LEITE, L. F. C. Modelagem matemática e simulação da dinâmica da matéria orgânica do solo. In: ROSCOE, R.; MERCANTE, F. M.; SALTON, J. C. (Ed.). Dinâmica da matéria orgânica do solo em sistemas conservacionistas: modelagem matemática e métodos auxiliares. Dourados: Embrapa Agropecuária Oeste, 2006. p. 75-106.

MEYSNER, T.; SZAJDAK, L.; KUS, J. Impact of the farming systems on the content of biologically active substances and the forms of nitrogen in the soils. Agronomy Research, Tartu, Stonia, v. 4, n. 2, p. 531-542, 2006. 
MIRANDA, M. J.; PINTO, H. S.; ZULLO-JÚNIOR; J.; FAGUNDES, R. M.; FONSECHI, D. B.; CALVE, L.; PELleGRINO, G. Q. Clima dos Municípios Paulistas - Piracicaba: Centro de Pesquisas Meteorológicas e Climáticas Aplicadas à Agricultura. Campinas: CEPAGRI/UNICAMP, 2011. Disponível em: <http://www.cpa.unicamp.br/outrasinformacoes/clima_muni_436.html>. Acesso em: 20 jun. 2014.

MORLEY, N.; BAGGS, E. M.; DÖRSCH, P.; BAKKEN, L. Production of NO, $\mathrm{N}_{2} \mathrm{O}$ and $\mathrm{N}_{2}$ by extracted soil bacteria, regulation by $\mathrm{NO}_{2}{ }^{-}$and $\mathrm{O}_{2}$ concentrations. FEMS Microbiology Ecology, Amsterdam, v. 65, p. 102-12, 2008.

MOSIER, A. R. Soil processes and global change. Biology and Fertility of Soils, Berlin, v. 27, p. 221-229, 1998.

MULLIS, K. B. Target amplification for DNA analysis by the polymerase chain reaction. Annales de Biologie Clinique, Paris, v. 48, n. 8, p. 579-582, 1990.

NELSON, D. W.; SOMMERS, L. E. Total carbon, organic carbon and organic matter. In: PAGE, A. L.; MILlER, R. H.; KENNEY, D. R. (Ed.). Methods of soil analysis. 2. ed. Madison: American Society of Agronomy, 1982. p. 539-579.

NOVAIS, C. M.; PIRES-ALVES, M.; SILVA, F. F. PCR em tempo real. Biotecnologia Ciência \& Desenvolvimento, Brasília, DF, v. 33, p. 10-13, 2004.

OSBORN, A. M.; MOORE, E. R. B.; TIMMIS, K. N. An evaluation of terminal-restriction fragment length polymorphisms (T-RFLP) analysis for the study of microbial community structure and dynamics. Environmental Microbiology, Oxford, v. 2, p. 39-50, 2000.

PHILIPPOT, L. Denitrifying genes in bacterial and Archeal genomes. Biochimica et Biophysica Acta, Amsterdam, v. 1577, p. 355-376, 2002.

PHILIPPOT, L.; ANDERT, J.; JONES, C. M.; BRU, D.; HALLIN, S. Importance of denitrifiers lacking the genes encoding the nitrous oxide reductase for $\mathrm{N}_{2} \mathrm{O}$ emissions from soil. Global Change Biology, Oxford, v. 17, p. 1497-1504, 2011.

PHILIPPOT, L.; ČUHEL, J.; SABY, N. P. A; CHÈNEBY, D.; CHROŇÁKOVÁ, A.; BRU, D.; ARROUAYS, D.; MARTIN-LAURENT, F.; ŠIMEK, M. Mapping field-scale spatial patterns of size and activity of the denitrifier community. Environmental Microbiology, Oxford, v. 11, p. 1518-1526, 2009.

PHILIPPOT, L.; HALLIN, S. Finding the missing link between diversity and activity using denitrifying bacteria as a model functional community. Current Opinion in Microbiology, London, v. 8, p. 234-239, 2005.

POTH, M.; FOCHT, D. D. ${ }^{15} \mathrm{~N}$ kinetic analysis of $\mathrm{N}_{2} \mathrm{O}$ production by Nitrosomonas europaea - an examination of nitrifier denitrification. Applied and Environmental Microbiology, Washington, DC, v. 49, p. 1134-1141, 1985. 
PRATHER, M.; DERWENT, R.; EHHALT, D.; FRASER, P.; SANHUEZA, E.; ZHOU, X. Other trace gases and atmospheric chemistry. In: HOUGHTON, J. T.; MEIRA FILHO, L. G.; BRUCE, J.; LEE, H.; CALLANDER, B. A.; HAITES, E.; HARRIS, N.; MASKELL, K. (Ed.). Climate Change 1994: Radiative Forcing of Climate Change and an Evaluation of the IPCC IS92 Emission Scenarios. Cambridge: Cambridge University Press, 1995. p. 73-126.

RAIJ, B. V.; CANTARELlA, H.; QUAGGIO, J. A.; FURLANI, A. M. C. Recomendações de adubação e calagem para o Estado de São Paulo. 2. ed. Campinas: IAC, 1997. 285 p. (Boletim Técnico, 100).

RAMASWAMY, V.; BOUCHER, O.; HAIGH, J.; HAUGHUSTAINE, D.; HAYWOOD, J.; MYHRE, G.; NAKAJIMA, T.; SHI, G. Y.; SOLOMON, S. Radiative forcing of climate change. In: HOUGHTON, J. T.; DING, Y.; GRIGGS, D. J.; NOGUER, M.; van der LINDEN, P. J.; DAI, X.; MASKELL, K.; JOHNSON, C. A. (Ed.). Climate Change 2001: The Scientific Basis. Cambridge: Cambridge University Press, 2001. p. 349-416.

RAVISHANKARA, A. R.; DANIEL, J. S.; PORTMANN, R. W. Nitrous oxide $\left(\mathrm{N}_{2} \mathrm{O}\right)$ : the dominant ozone-depleting substance emitted in the 21st century. Science, Washington, DC, v. 326, p. 123-125, 2009.

RENAULT, P.; SIERRA, J. Modelling oxygen diffusion in aggregated soils. 2. Anaerobiosis in topsoil layers. Soil Science Society of America Journal, Madison, v. 58, p. 1023-1030, 1994.

RICH, J. J.; MYROLD, D. D. Community composition and activities of denitrifying bacteria from adjacent agricultural soil, riparian soil, and creek sediment in Oregon, USA. Soil Biology \& Biochemistry, Oxford, v. 36, p. 1431-1441, 2004.

RICHARDSON, D. J. Bacterial respiration: a flexible process for a changing environment. Microbiology, Reading, v. 146, p. 551-571, 2000.

RICHARDSON, D. J.; FELGATE, H.; WATMOUGH, N.; THOMSON, A.; BAGGS, E. Mitigating release of the potent greenhouse gas $\mathrm{N}_{2} \mathrm{O}$ from the nitrogen cycle - could enzymatic regulation hold the key? Trends in Biotechnology, London, v. 27 p. 388-397, 2009.

RIRIE, K. M.; RASMUSSEN, R. P.; WITTWER, C. T. Product differentiation by analysis of DNA melting curves during the polymerase chain reaction. Analytical Biochemistry, New York, v. 245, n. 2, p. 154-160, 1997.

RONQUIM, C. C. Conceitos de fertilidade do solo e manejo adequado para as regiões tropicais. Campinas: Embrapa Monitoramento por Satélite, 2010. 26 p. (Boletim de Pesquisa e Desenvolvimento, 8).

RUDAZ, J.; WALTI, E.; KUBURZ, G.; LEHMANN, P.; FUHRER, J. Temporal variation in $\mathrm{N}_{2} \mathrm{O}$ and $\mathrm{N}_{2}$ fluxes from permanent pasture in Switzerland in relation to management, soil water content and soil temperature. Agriculture, Ecosystems \& Environment, Amsterdam, v. 73, p. 83-91, 1999. 
RUTLEDGE, R. G.; COTE, C. Mathematics of quantitative PCR and the applications of standard curves. Nucleic Acids Research, London, v. 31, n.16, e93, 2003.

SAGGAR, S.; JHA, N.; DESLIPPE, J.; BOLAN, N. S.; LUO, J.; GILTRAP, D. L.; KIM, D.G.; ZAMAN, M.; TILLMAN, R. W. Denitrification and $\mathrm{N}_{2} \mathrm{O}: \mathrm{N}_{2}$ production in temperate grasslands: Processes, measurements, modelling and mitigating negative impacts. Science of the Total Environment, Amsterdam, v. 465, p. 173-195, 2013.

SAGGAR, S.; LUO, J.; GILTRAP, D. L.; MADDENA, M. Nitrous oxide emission from temperate grasslands: process, measurements, modelling and mitigation. In: SHELDON, A. I.; BARNHART, E. P. (Ed.). Nitrous oxide emissions research progress. New York: Nova Science Publishers; 2009. p. 1-66.

SAIKI, R. K.; GELFAND, D. H.; STOFFEL, S.; SCHARF, S. J.; HIGUCHI, R.; HORN, G. T.; MULLIS, K. B.; ERLICH, H. A. Primer-directed enzymatic amplification of DNA with a thermostable DNA polymerase. Science, Washington, DC, v. 239, v. 4839, p. 487-491, 1988.

SAMBROOK, J.; FRITSCH, E. F.; MANIATIS, T. Molecular cloning: a laboratory manual. 2. ed. New York: Cold Spring Harbor Laboratory Press, 1989.

SCHÄR, C.; VIDALE, P. L.; LUTHI, D.; FREI, C.; HABERLI, C.; LINIGER, M. A.; APPENZELLER, C. The role of increasing temperature variability in European summer heatwaves. Nature, London, v. 427, p. 332-336, 2004.

SCHLESINGER, W. H. Biogeochemistry: an analysis of global change. 2. ed. San Diego: Academic Press, 1997. 588 p.

SCHOLES, R. J.; BREEMEN, N. van. The effects of global change on tropical ecosystems. Geoderma, Amsterdam, v. 79, p. 9-24, 1997.

SEXSTON, A. J.; PARKIN, T. P.; TIEDJE, J. M. Temporal response of soil denitrification to rainfall and irrigation. Soil Science Society of America Journal, Madison, v. 49, p. 99-103, 1985.

SKIBA, U.; SMITH, K. A. The control of nitrous oxide emissions from agricultural and natural soils. Chemosphere - Global Change Science, Oxford, v. 2, p. 379-386, 2000.

SMITH, K. A. A model of the extent of anaerobic zones in aggregated soils, and its potential application to estimates of denitrification. Jounal of Soil Science, Oxford, v. 31, p. 263-277, 1980.

SMITH, P. Carbon sequestration in croplands: the potential in Europe and the global context. European Journal Soil Science, Oxford, v. 20, p. 229-236, 2004.

SMITH, P.; MARTINO, D.; CAI, Z.; GWARY, D.; JANZEN, H.; KUMAR, P. Agriculture. In: METZ, B.; DAVIDSON, O. R.; BOSCH, P. R.; DAVE, R.; MEYER, L. A. (Ed.). Climate Change 2007: Mitigation. Contribution of Working Group III to the Fourth Assessment Report of the Intergovernmental Panel on Climate Change. Cambridge: Cambridge University Press, 2007. p. 499-540. 
STARK. J. M.; FIRESTONE, M. K. Mechanisms for soil-moisture effects on the activity of nitrifying bacteria. Applied and Environmental Microbiology, Washington, DC, v. 61, p. 218-221, 1995.

STRES, B.; DANEVCIC, T.; PAL, L.; FUKA, M. M.; RESMAN, L.; LESKOVEC, S.; HACIN, J.; STOPAR, D.; MAHNE, I.; MANDIC-MULEC, I. Influence of temperature and soil water content on bacterial, archaeal and denitrifying microbial communities in drained fen grassland soil microcosms. FEMS Microbiology Ecology, Amsterdam, v. 66, p. 110-122, 2008.

SZAJDAK, L.; JEZIERSKI, A.; CABRERA, M. L. Impact of conventional and no-tillage management on soil amino acids, stable and transient radicals and properties of humic and fulvic acids. Organic Geochemistry, Bristol, v. 34, p. 693-700, 2003.

SZUKICS, U.; ABELL, G. C. J.; HOD, V.; MITTER, B.; SESSITSCH, A.; HACK, E.; ZECHMEISTER-BOLTENSTERN, S. Nitrifiers and denitrifiers respond rapidly to changed moisture and increasing temperature in a pristine forest soil. FEMS Microbiology Ecology, Amsterdam, v. 72, p. 395-406, 2010.

THIES, J. E. Soil microbial community analysis using terminal restriction fragment length polymorphisms. Soil Science Society of America Journal, Madison, v. 71, p. 579-591, 2007.

THOMAS, K. L.; LLOYD, D.; BODDY, L. Effects of oxygen, $\mathrm{pH}$ and nitrate concentration on denitrification by Pseudomonas species. FEMS Microbiology Letters, Amsterdam, v. 118, p. 181-186, 1994.

THOMSON, B. C.; OSTLE, N. J.; MCNAMARA, N. P.; WHITELEY, A. S.; GRIFFITHS, R. I. Effects of sieving, drying and rewetting upon soil bacterial community structure and respiration rates. Journal of Microbiological Methods, Amsterdam, v. 83, p. 69-73, 2010.

THROBÄCK, I. N.; ENWALL, K.; JARVIS, Å.; HALLIN, S. Reassessing PCR primers targeting nirS, nirK and nos $Z$ genes for community surveys of denitrifying bacteria with DGGE. FEMS Microbiology Ecology, Amsterdam, v. 49, p. 401-417, 2004.

TIEDJE, J. M. Ecology of denitrification and dissimilatory nitrate reduction to ammonium. In: ZEHNDER, A. J. B (Ed.). Biology of anaerobic microorganisms. New York: Wiley \& Sons, 1988. p. 179-244.

TIEDJE, J. M.; ASUMING-BREMPONG, S.; NUSSLEIN, K.; MARSH, T. L.; FLYNN, S. J. Opening the black box of soil microbial diversity. Applied Soil Ecolology, Amsterdam, v. 13, p. 109-122, 1999.

TIEDJE, J. M.; SETONE, A. J.; PARKIN, T. B.; REVSBECH, N. P.; SHELTON, D. R. Anaerobic processes in soil. Plant and Soil, Dordrecht, v. 76, p. 197-212, 1984.

TORSVIK, V.; DAAE, F. L.; SANDAA, R. A.; OVREAS, L. Review article: novel techniques for analysing microbial diversity in natural and perturbed environments. Jounal Biotechnology, New York, v. 64, p. 53-62, 1998. 
VAN SPANNING, R. J. M.; RICHARDSON, D.; FERGUSON, S. Introduction to the biochemistry and molecular biology of denitrification. In: BOTHE, H.; FERGUSON, S. J.; NEWTON, W. E. (Ed.). Biology of the nitrogen cycle. Amsterdam: Elsevier, 2007. cap. 1, p. 382-395.

VELTHOF, G. L.; OENEMA, O. Nitrous oxide fluxes from grassland in the Netherlands, II, Effects of soil type, nitrogen fertilizer application and grazing. European Journal of Soil Science, Oxford, v. 46, p. 541-549, 1995.

WALLENSTEIN, M. D.; MYROLD, D. D.; FIRESTONE, M.; VOYTEK, M. Environmental controls on denitrifying communities and denitrification rates: insights from molecular methods. Ecological Applications, Washington, DC, v. 16, p. 2143-2152, 2006.

WALLENSTEIN, M. D.; VILGALYS, R. J. Quantitative analyses of nitrogen cycling genes in soils. Pedobiologia, Berlin, v. 49, p. 665-672, 2005.

WEIER, K. L.; DORAN, J. W.; POWER, J. F.; WALTERS D. T. Denitrification and the dinitrogen/nitrous oxide ratio as affected by soil water, available carbon, and nitrate. Soil Science Society of America Journal, Madison, v. 57, p. 66-72, 1993.

WEISBURG, W. G.; BARNS, S. M.; PELLETIER, D. A.; LANE.; D. J. 16S ribosomal DNA amplification for phylogenetic study. Journal of Bacteriology, Washington, DC, v. 173, p. 697-703, 1991.

WLODARCZYK, T.; STEPNIEWSKA, Z.; BRZEZINSKA, M. Denitrification, organic matter, and redox potential transformations in Cambisols. International Agrophysics, Budapest, v. 17, p. 219-227, 2003

WRAGE, N.; VELTHOF, G. L.; VAN BEEUUSICHEM, M. L.; OENEMA, O. Role of nitrifier denitification in the production of nitrous oxide. Soil Biology \& Biochemistry, Oxford, v. 33, p. 1723-1732, 2001.

ZUMFT, W. G. Cell biology and molecular basis of denitrification? Microbiologia e Biologia Molecular, Washington, DC, v. 61, p. 533-616, 1997.

ZUMFT, W. G. The biological role of nitric oxide in bacteria. Archives of Microbiology, Berlin, v. 160, p. 253-264, 1993. 